\title{
ILW-VORK - PLAISANCE
}
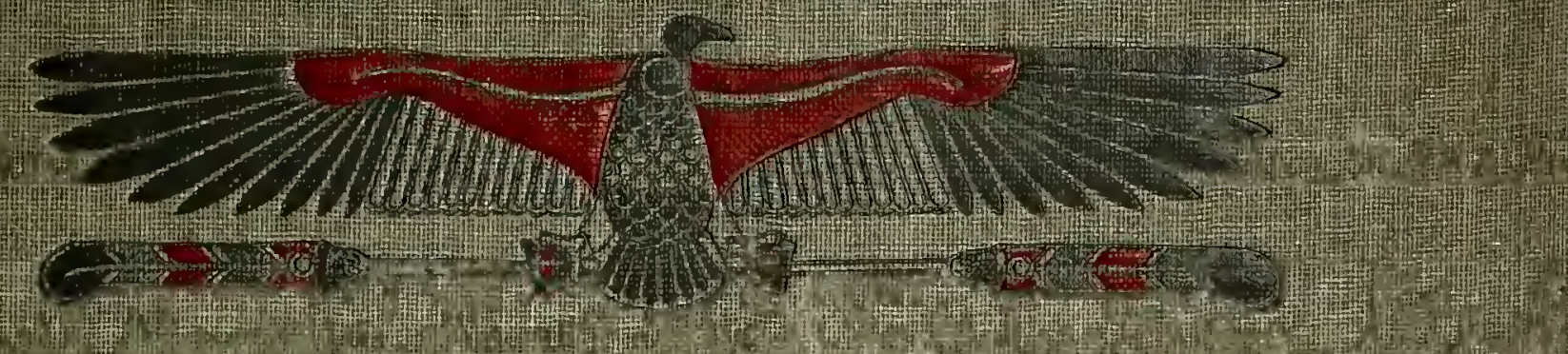

(1)

-

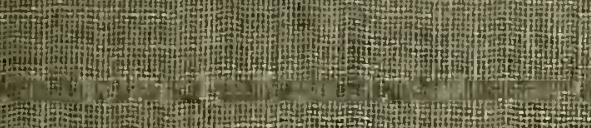

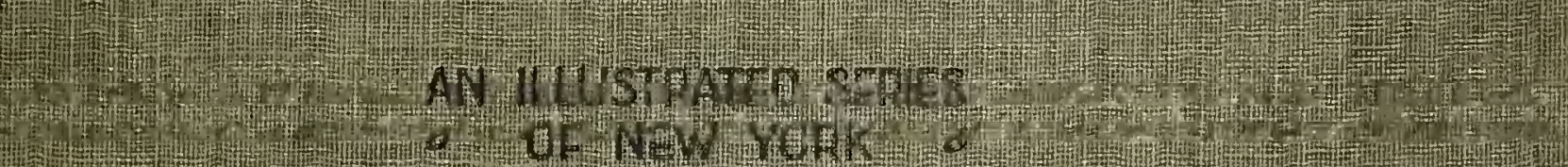

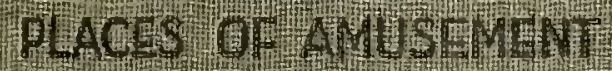

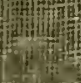

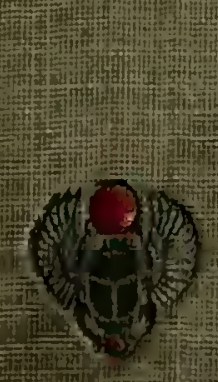

s.

(1)

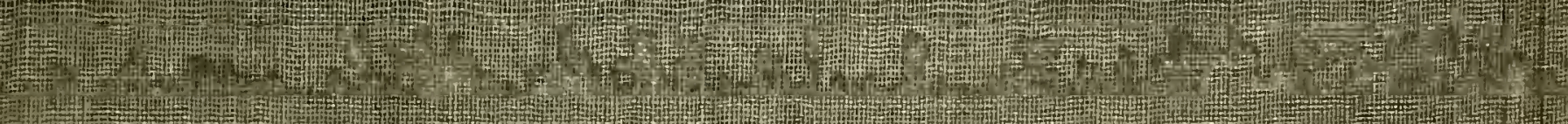

- 


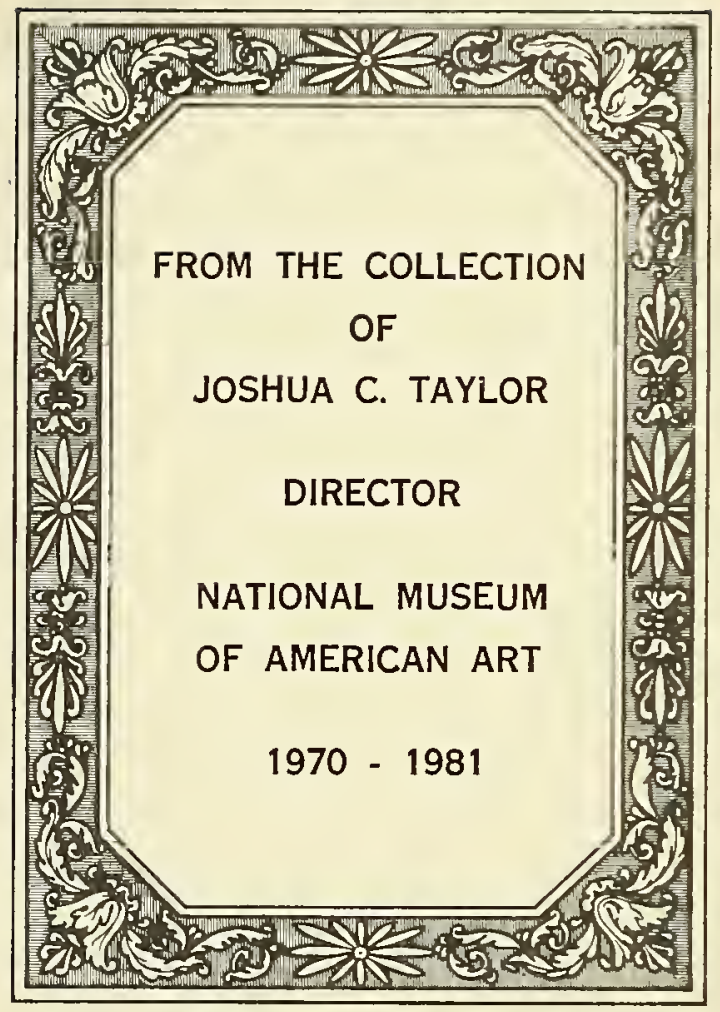




2002

.153

NMAA

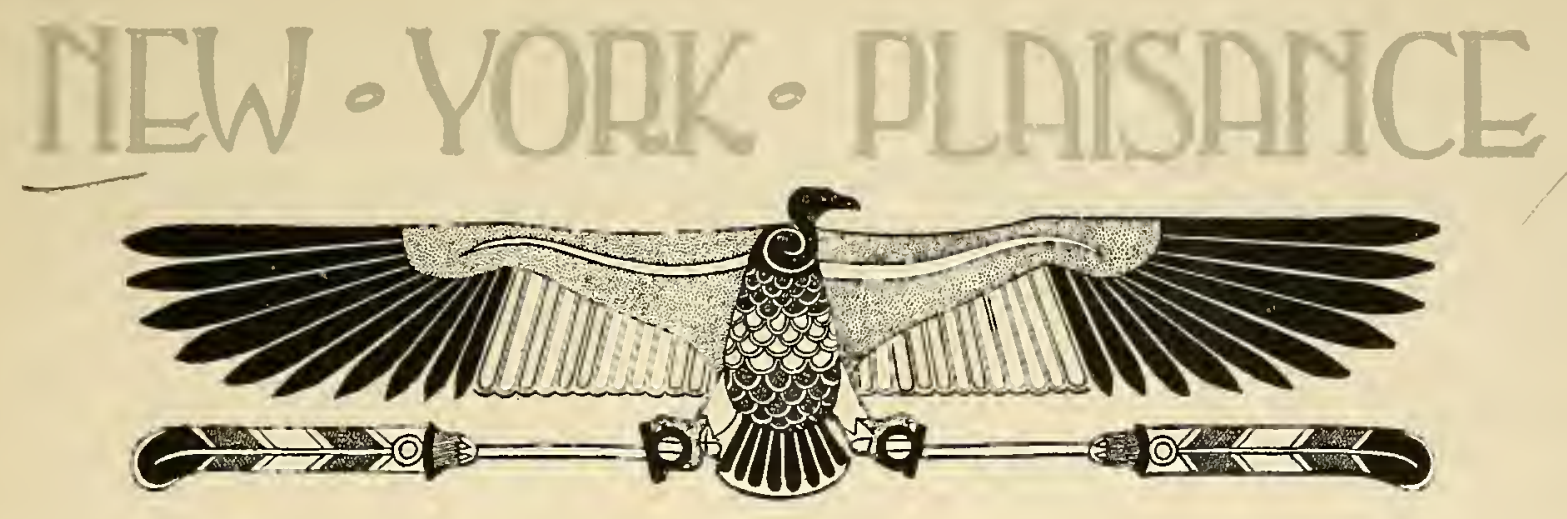

NUMBER ONE MDCCCCVIII AN ILLUSTRATED SERIES

- OF NEW YORK O

PLACES OF AMUSEMENT

It.engat Herrit.
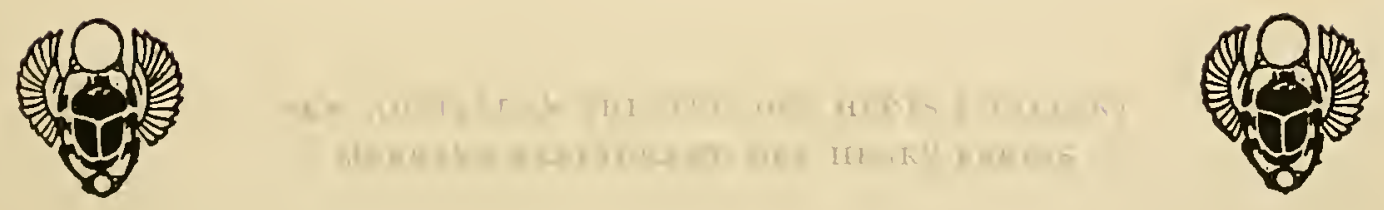

MAY 231984

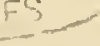


Copyright 1908

Henry Erkins. 

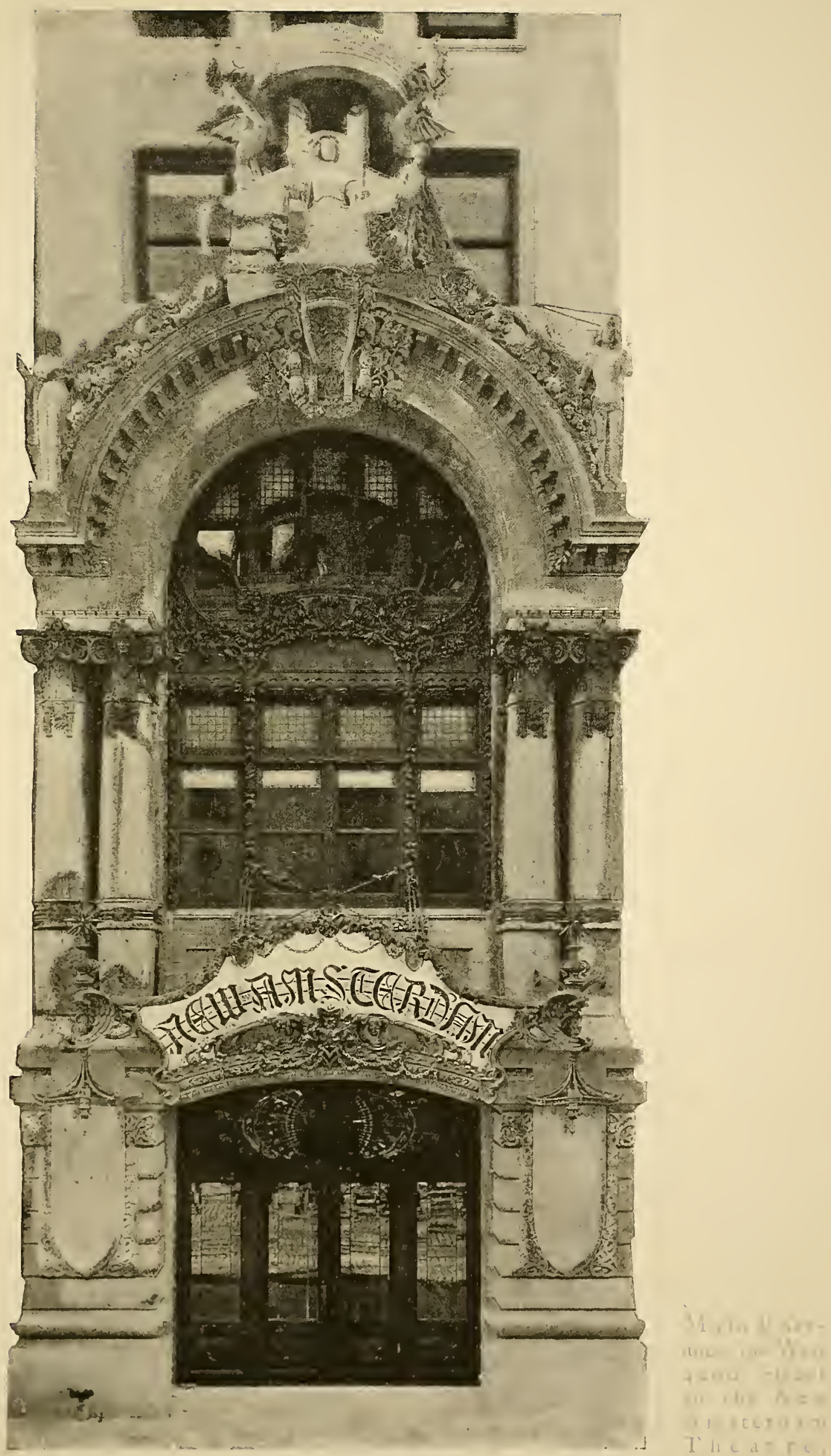



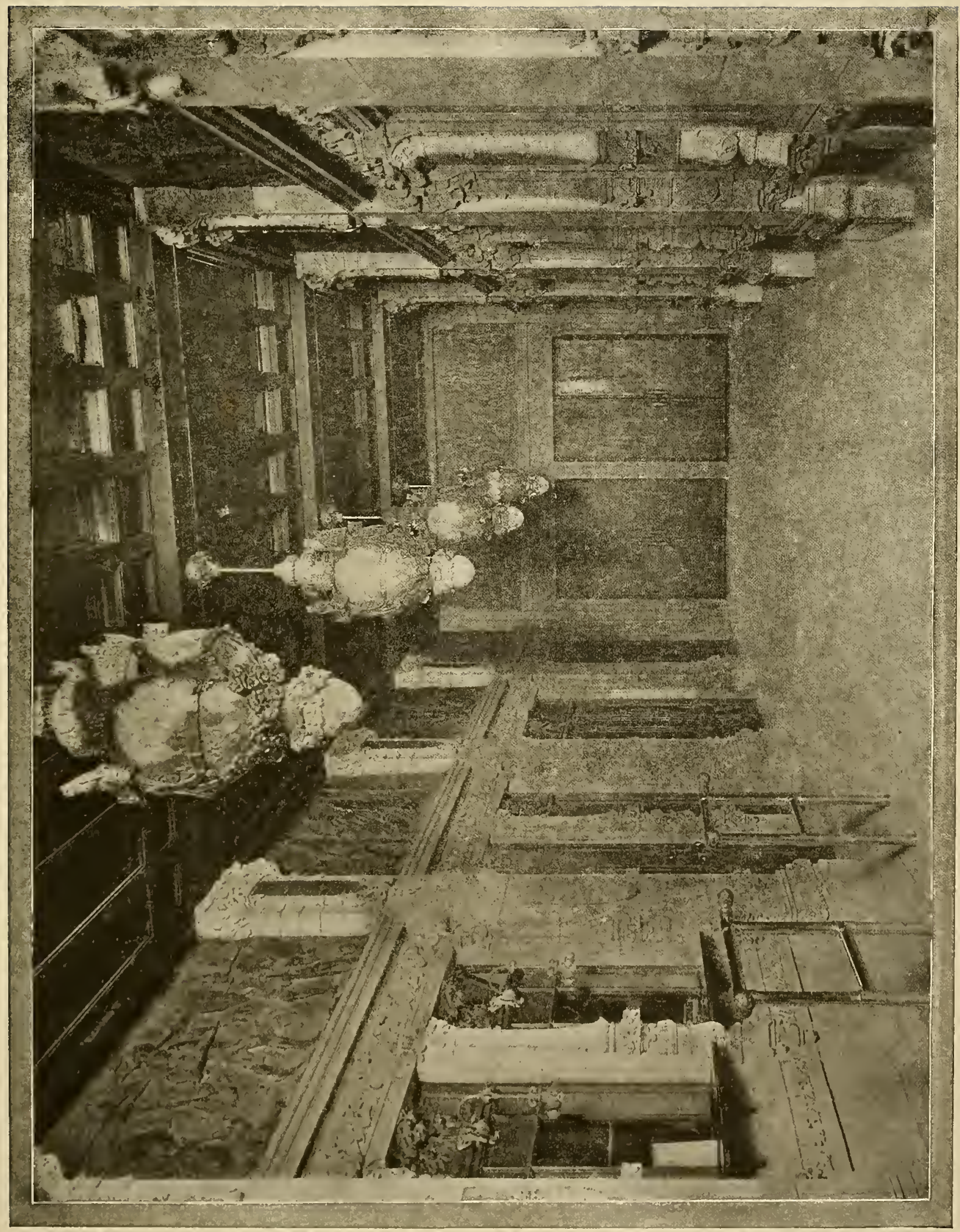





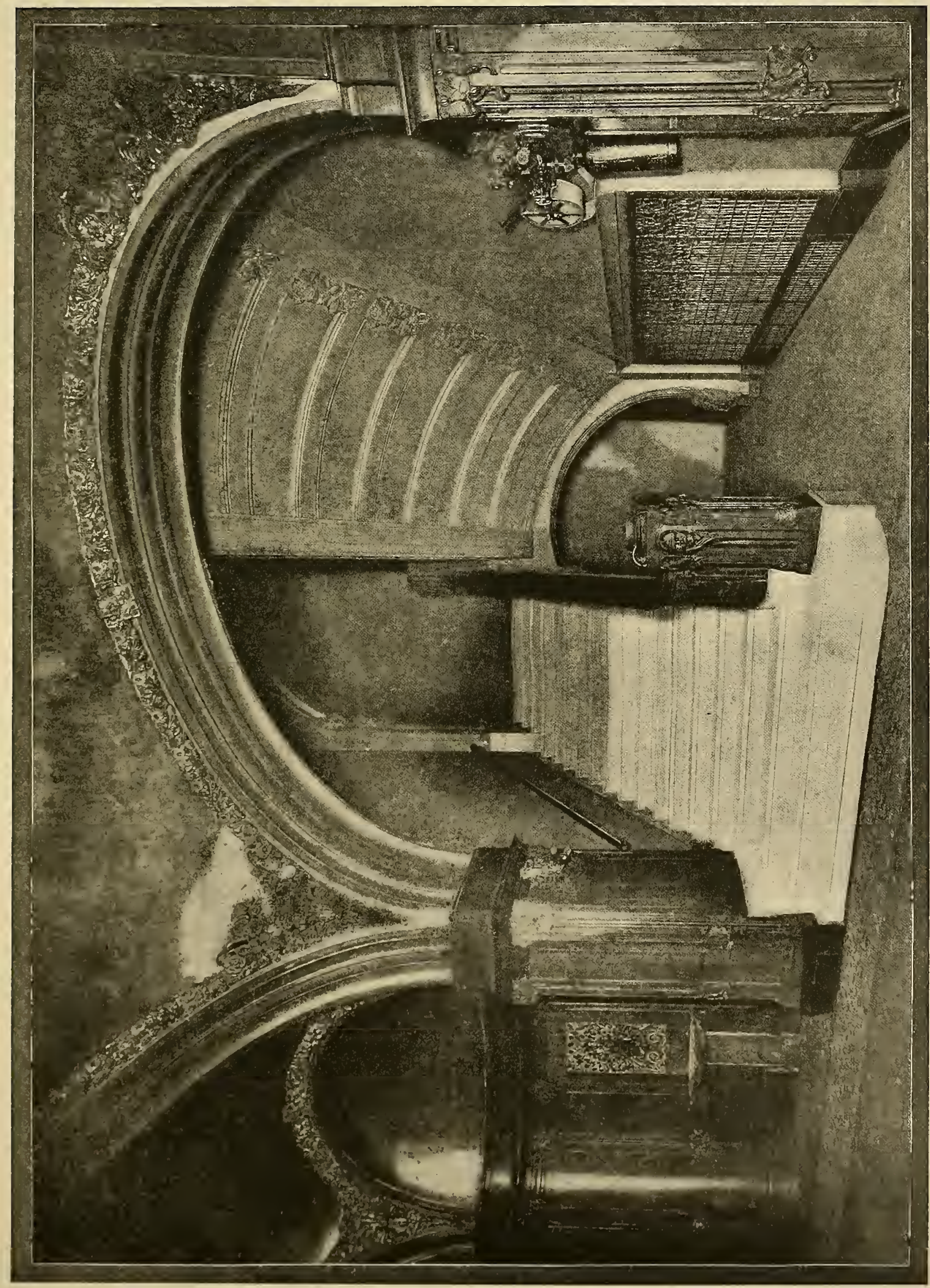




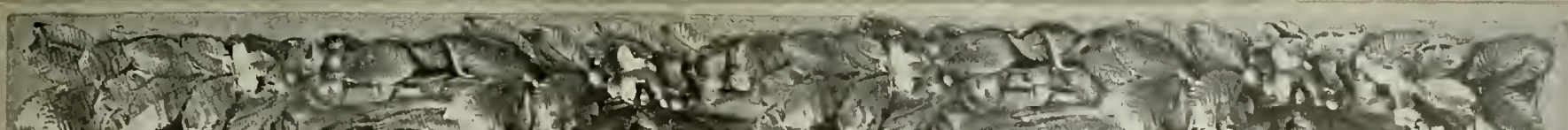

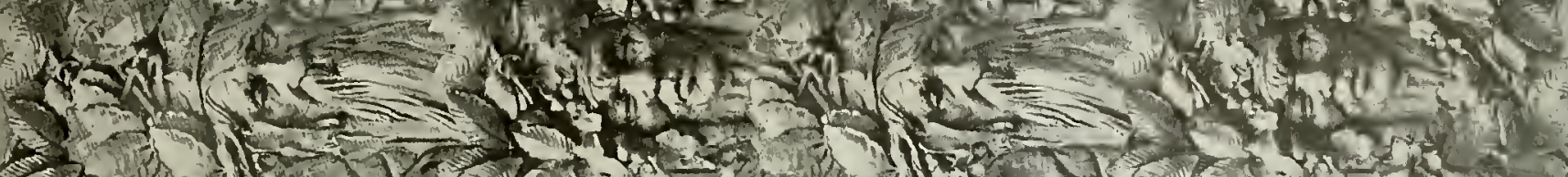

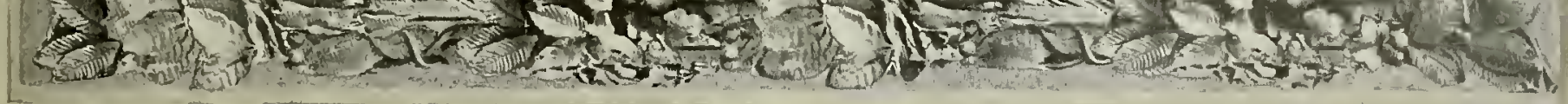

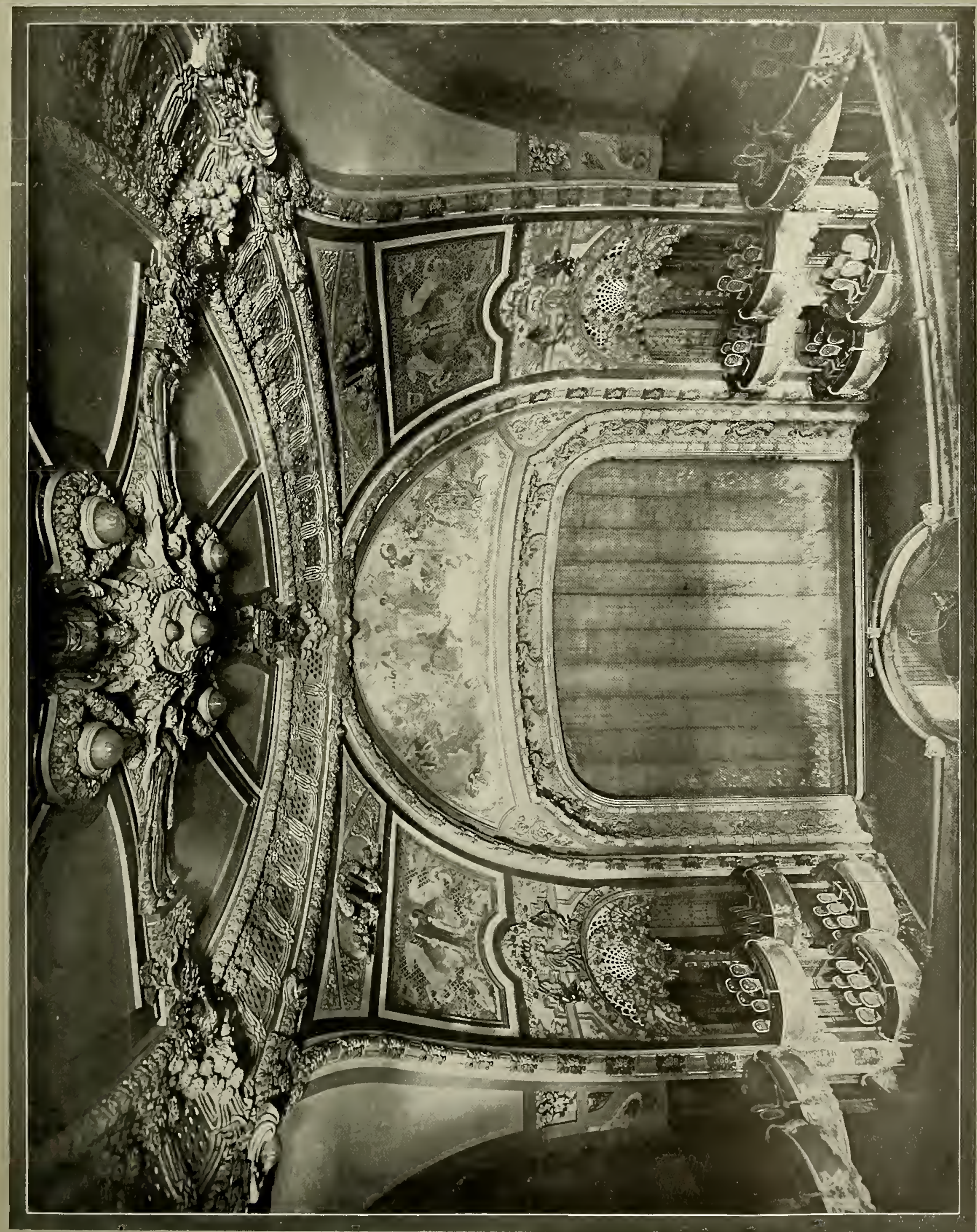

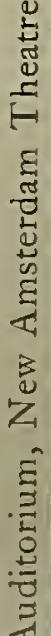


Disposition of boxes and allegorical decorative panel above the box tier, New Amsterdam Theatre. Occupants of boxes have unobstructed view of the stage and of all parts of the house. 


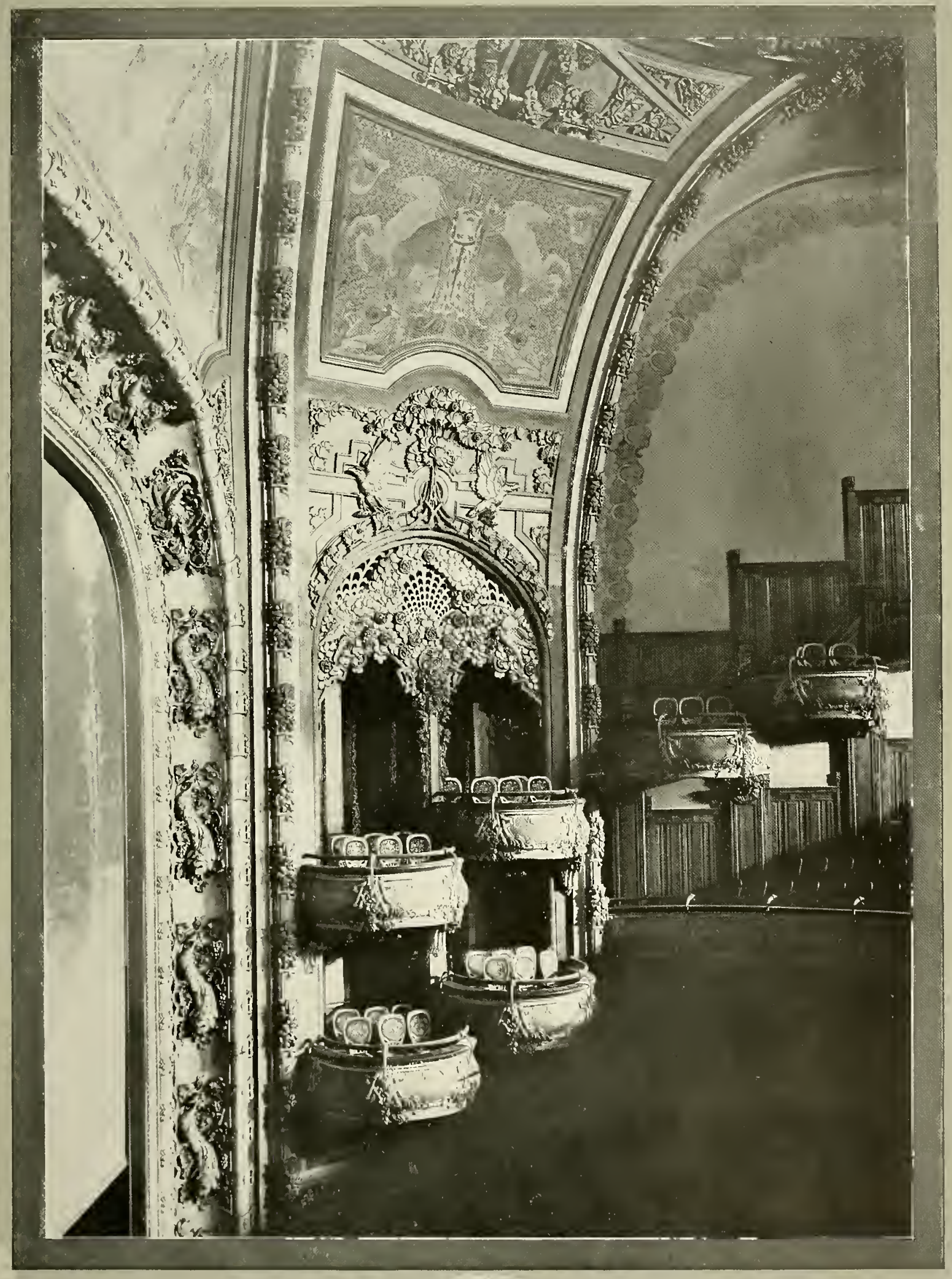



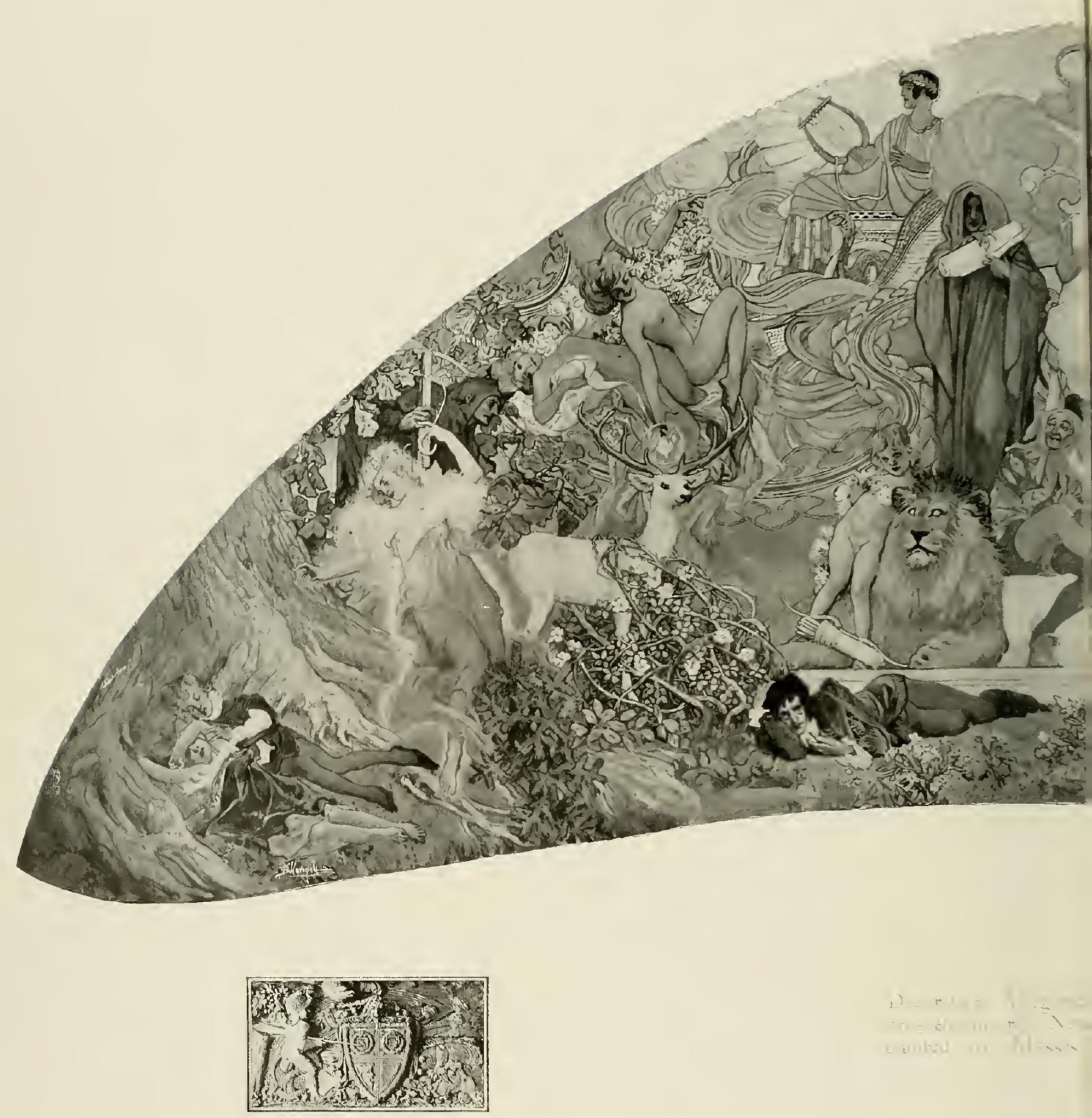



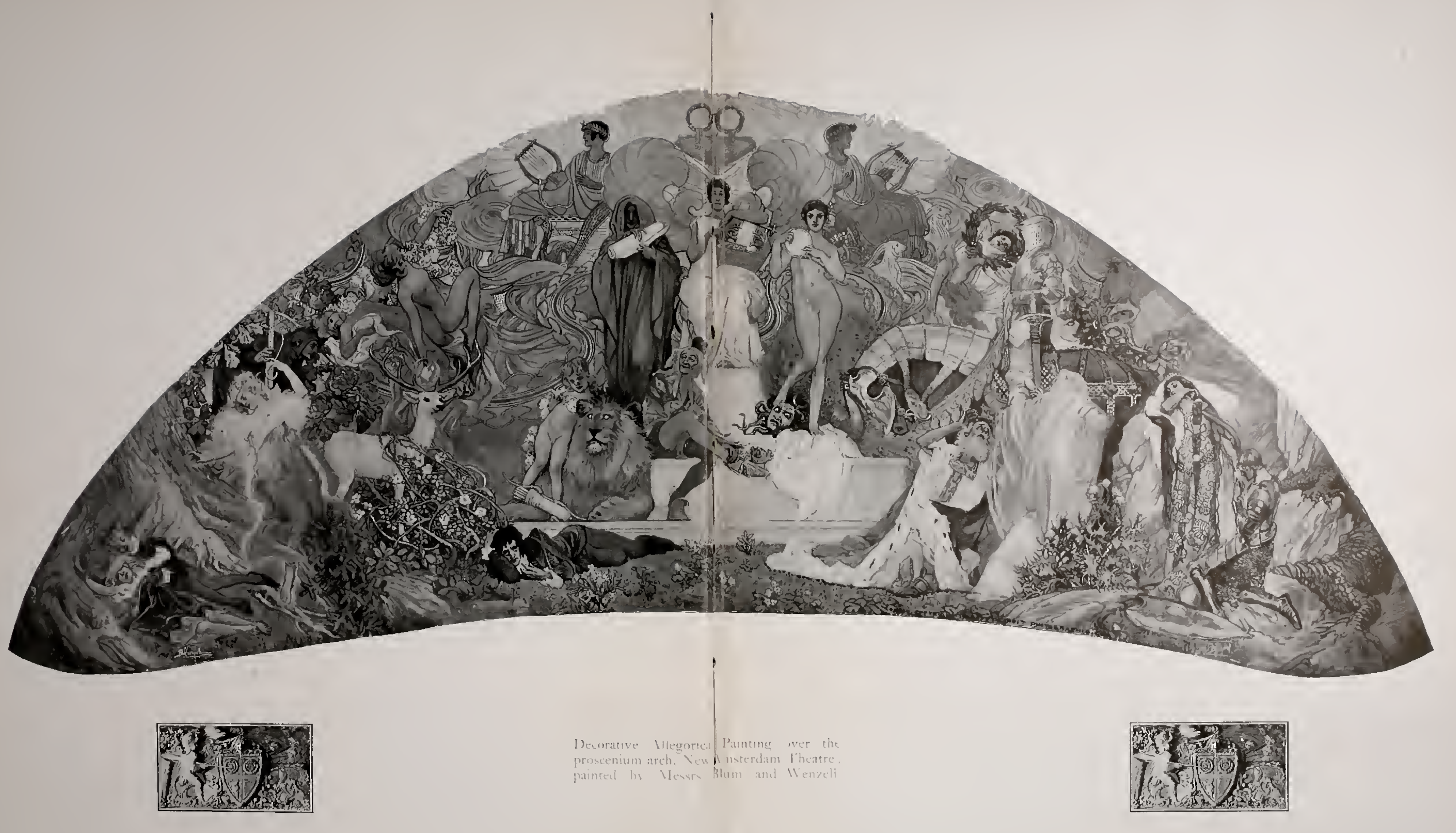




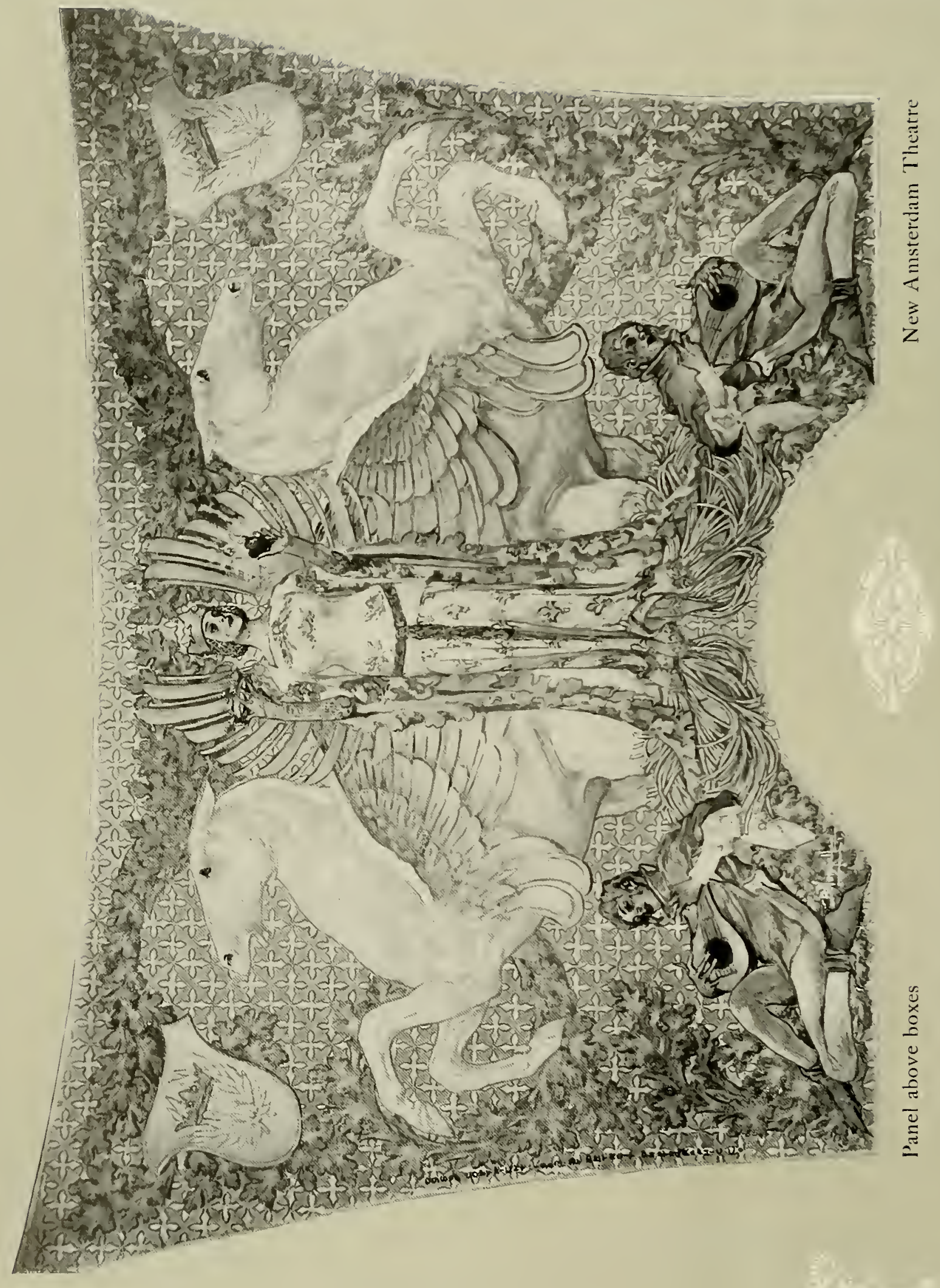




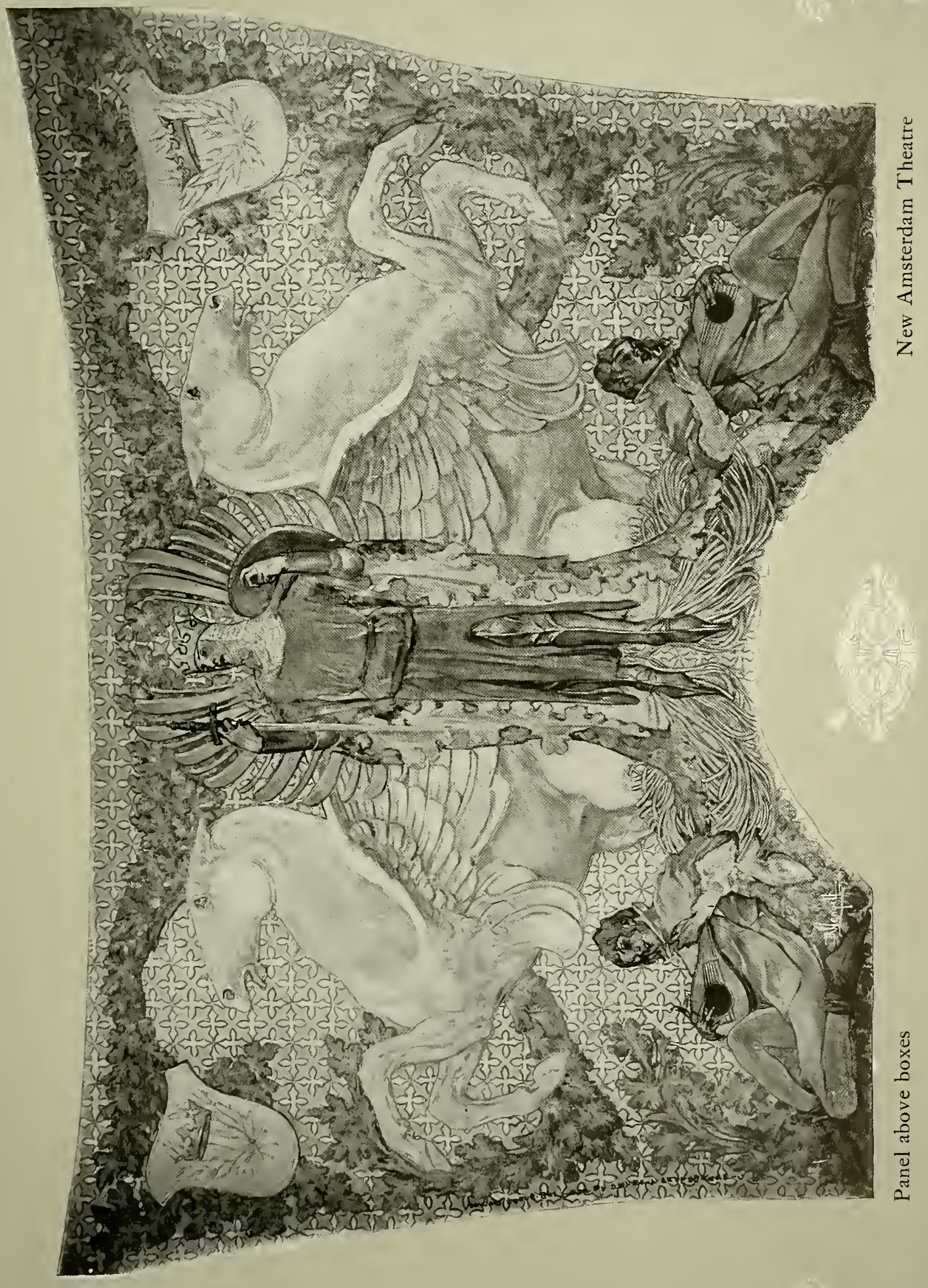




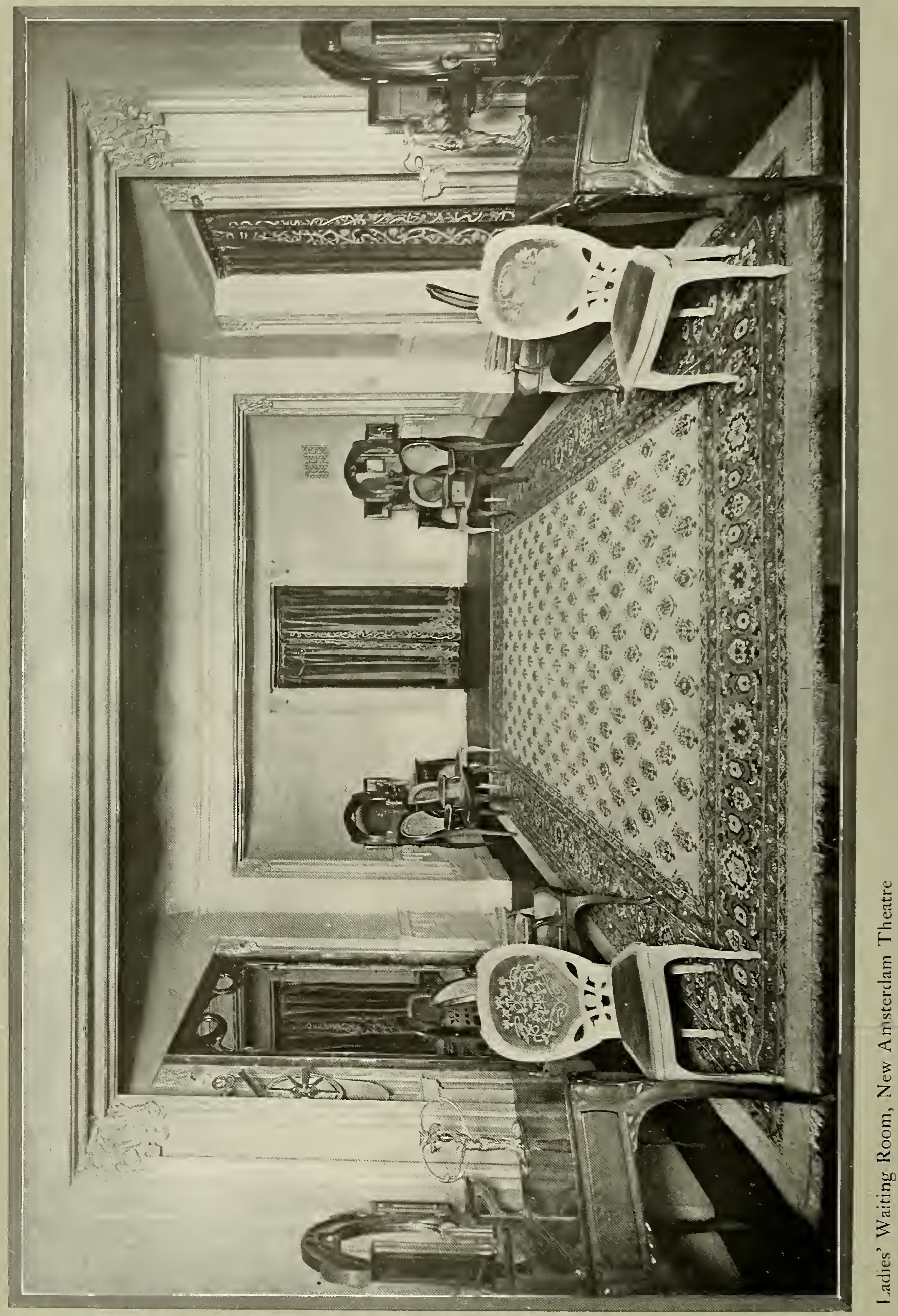




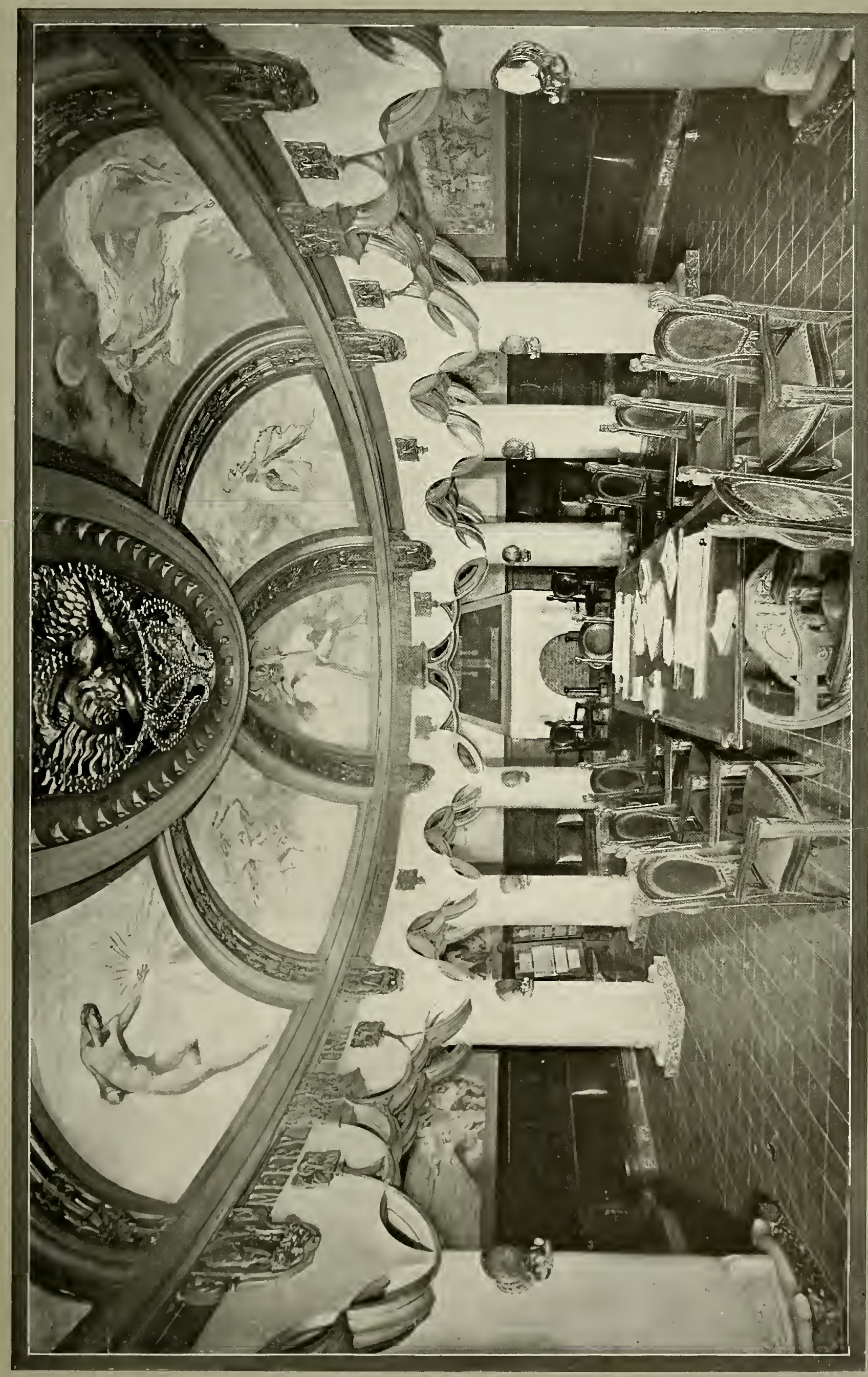

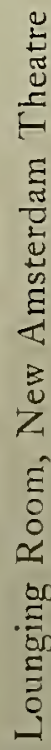




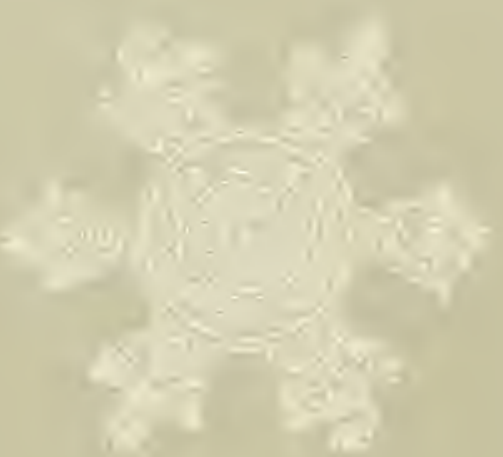

Grand Fover, New Amsterdam Theatre
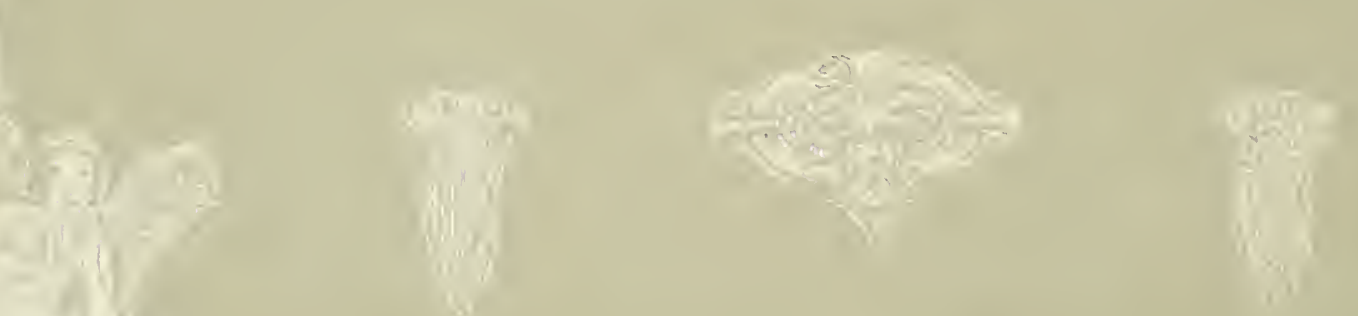


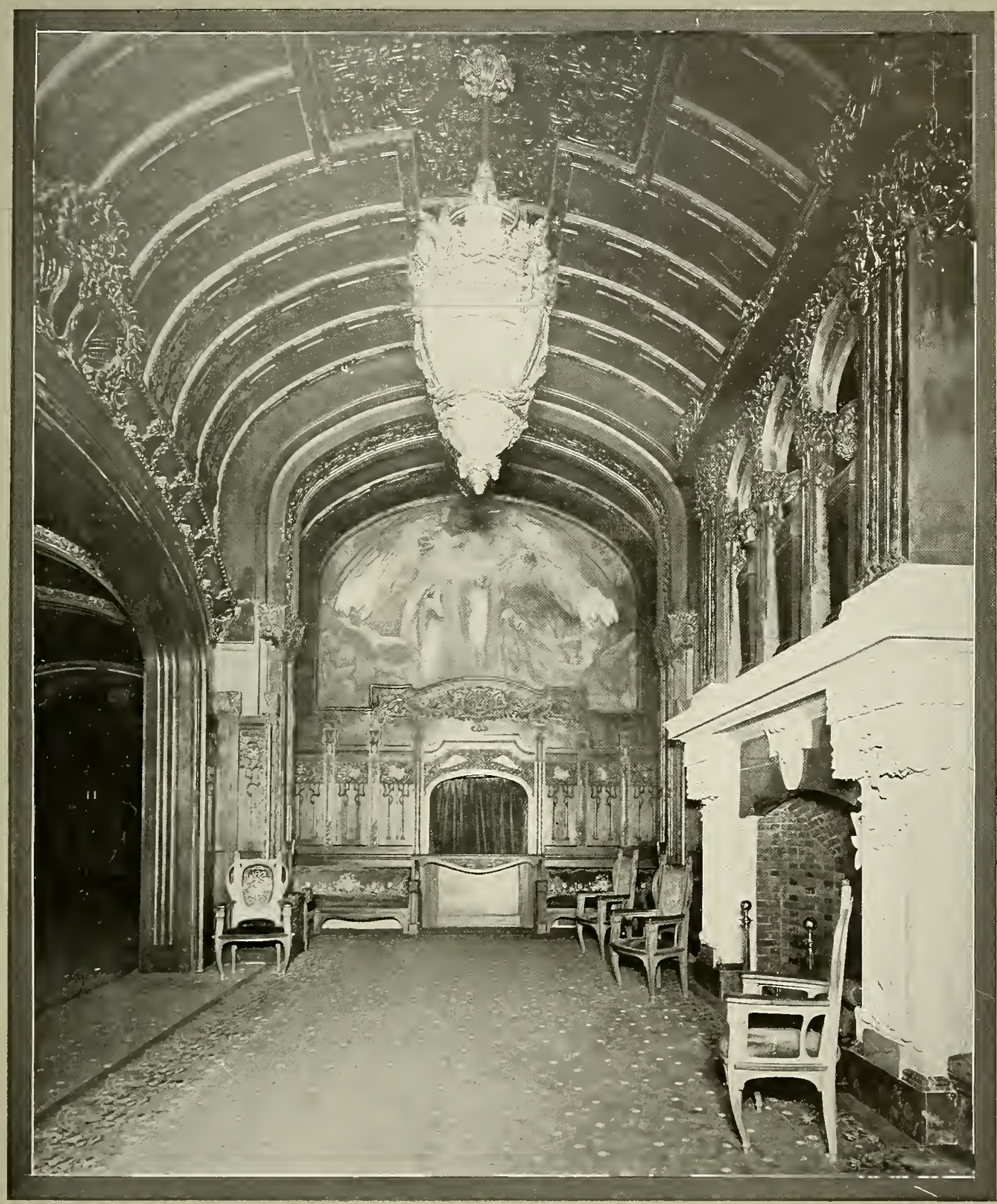




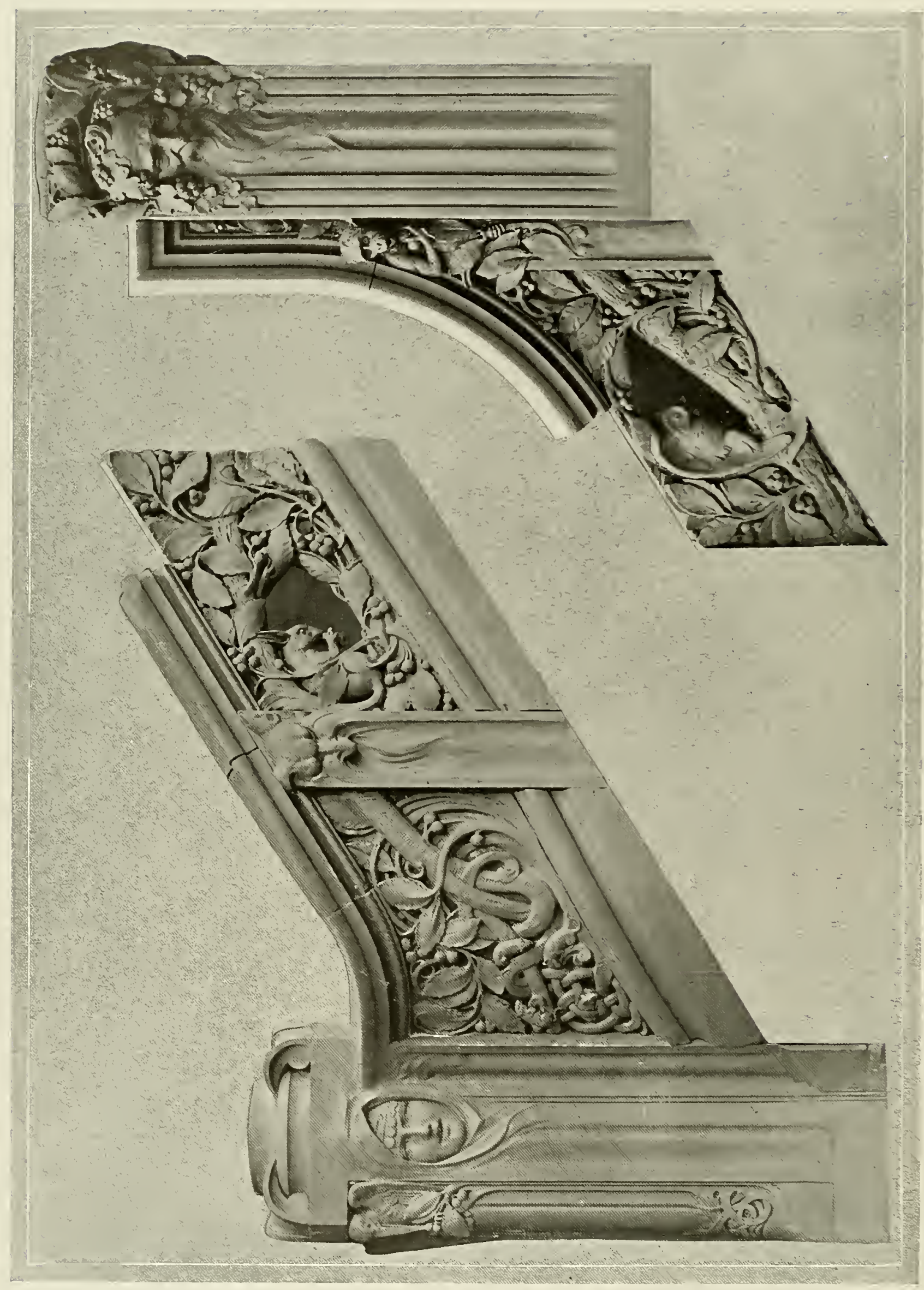



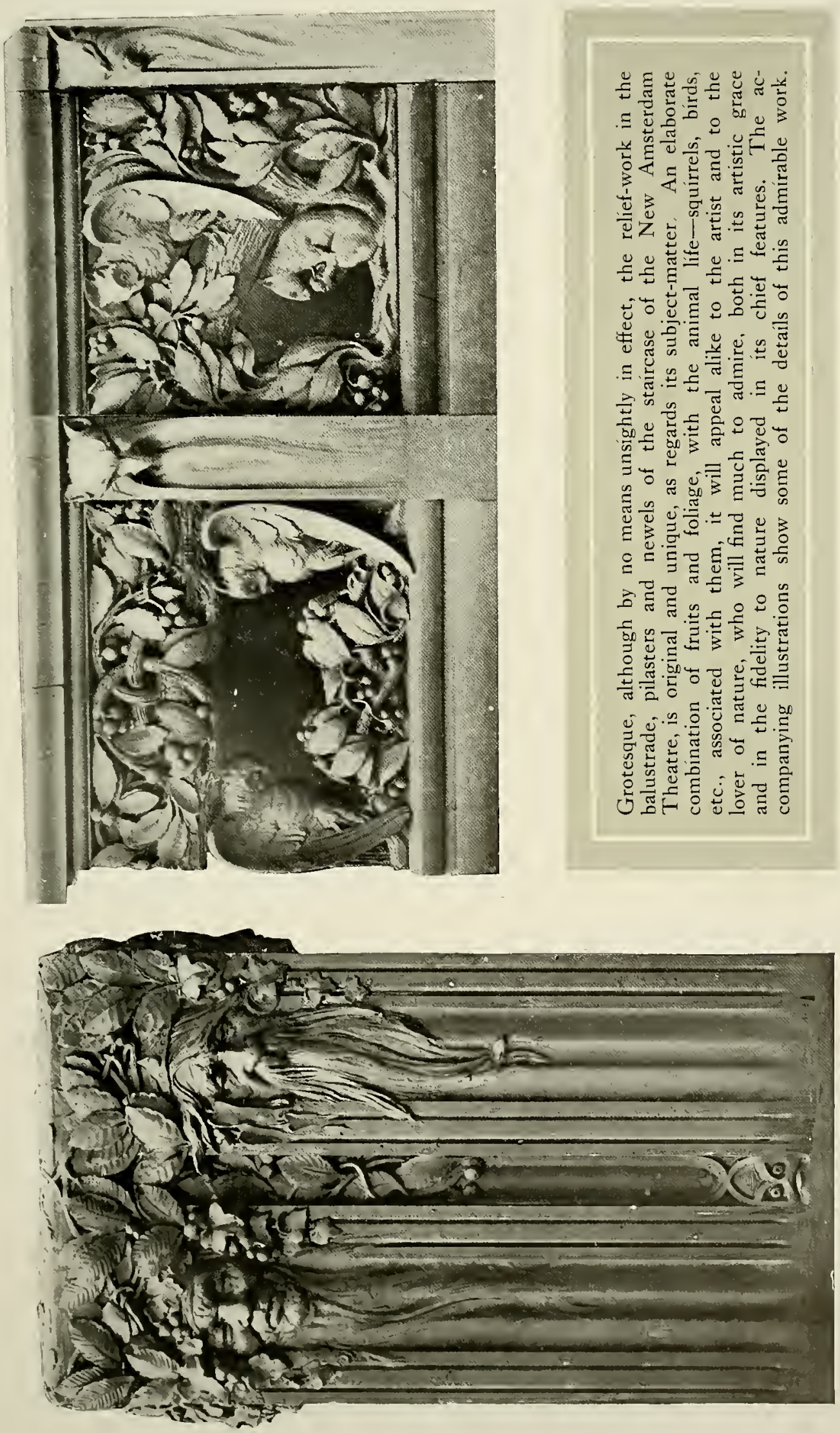


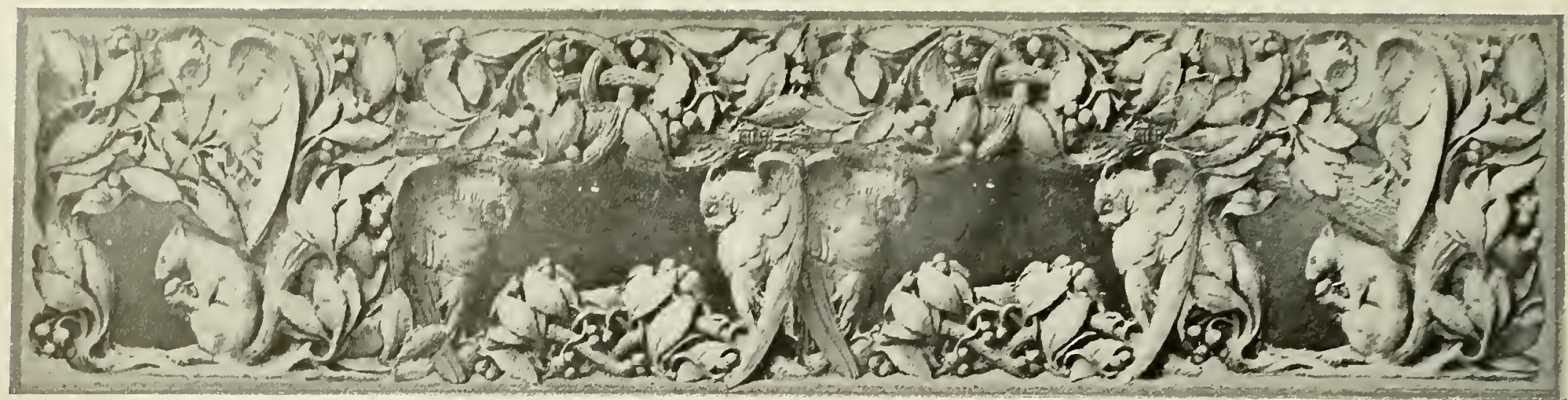

\section{RECORD of the progress of New York as a community, to cover the past decade, which might properly include a list of the additions made to the city's architectural marvels, the improvements in methods of transportation, the growth of the city's commerce and industries, the increase in her share of the world's wealth, and the manifold additions made to her artistic treasures, while instructive and interesting, would be incomplete without reference to} the marked development in the means of recreation and pleasure, the Empire City of the west affords. It is a notable fact that the provisions made for the entertainment of New Yorkers, and of those sojourning within the city's limits, have advanced of late by leaps and bounds, not alone in variety and originality, but in the direction of refinement; and, while the reckless abandon that characterizes pleasure-seeking in some cities has never found place in the metropolis of the western world, we have at our command means of enjoyment that are alike unique, luxurious and recherche, and which appeal especially to those whose appreciation of the good things of life is materially enchanced by refined and artistic surroundings. Those who cater to the entertainment of the public, have developed an increasing tendency to meet this happy evolution of the general taste, and among the establishments in which this commendable ambition is particularly in evidence, we accord the foremost place, by right of elegance and their unique character, to the New Amsterdam Theatre on West Forty-second Street, New York, and Murray's Restaurant, with its exquisite Roman gardens, on the same thorouginfare. In the New Amsterdam Theatre, located on West Forty-second Street, between the Seventh and Eighth Avenues, New York, we have, first of all, a most beautiful and commodious place of anusement; also, from the constructional standpoint a notable example of the efforts that are being made nowadays, by those who aspire to eminence as architects and designers, to depart from the traditional—we had almost said the commonplace-in style. In our modern buildings, regardless, of their purpose, we are so accustomed to find a more or less servile adherence to the old systems, that their chief features, with such unimportant variations as occur casually to those entrusted with their planning and erection, have become impressed upon us, and any radical attempt to depart from conventionalities at once arouses critical attention. The New Amsterdam Theatre owes the interest it has excited, on the part, not only of the theatre-going public, but of competent critics, to this evident determination on the part of its designers to depart from the beaten track, and for this reason, the accompanying illustrations and brief description of some of its unique features, will doubtless interest our readers. We must, however, preface our remarks with the admission that the cold black and white of print, although enabling us to depict, with the assistance of the photographic art, the diginity and beauty of form so much admired in this addition to the city's playhouses, with some fidelity, can give no idea of the artistic delicacy and successful boldness of the color scheme, which at once attracts and entrances the visitor. The designers have undertaken, in addition to a display of vigor and grace of form, to give practical expression to their originality of idea and execution; and the effect, while kaleidoscopic in the diversity and richness of its contrasts, will not only withstand analysis as to detail, but as a whole it presents a harmonious and grateful color scheme that can not fail to impress itself on the visitor as distinctly a factor in the preeminence of this, as in the truest sense of the term, a place of recreation. Mere gorgeousness in itself brings neither pleasure nor satisfaction to the cultured mind, but here we have the restfulness of change in the harmonious combination of color, form and general design, in which flowers, fruits and animal types have been skilfully combined, that does not meet the eye in the every-day walks of life and which the true artist in decoration learns to turn to account; in these respects the New Amsterdam Theatre can not fail to impress its patrons. There is moreover a harmony between the structural and decorative 


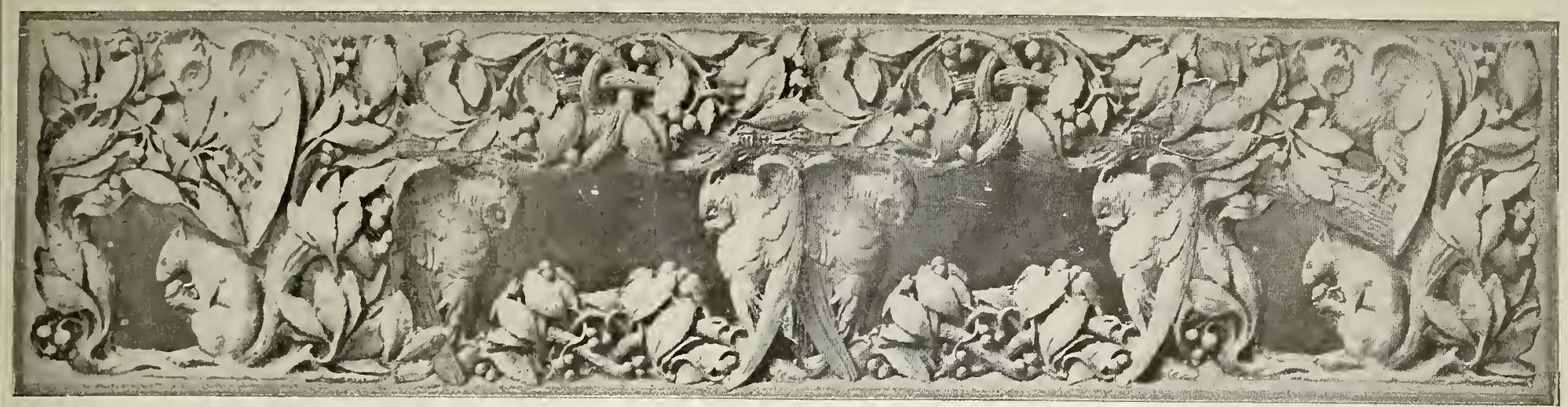

effects, attainable only, where, as in the case of this theatre, the same master minds have controlled every detail of the work. Such has indeed been the case with this building, so that construction, arrangement, relief ornaments, metal work, color effects, furnishings, draperies, etc., all bear the unmistakeable impress of the genius that has created the harmonious whole. The limited frontage of the theatre, on Forty-second Street, has been made the most of by the architects, Messrs. Herts \& Tallant, in designing the facade, which, without any overcrowding of the restricted space, conveys at once the idea of a structure of more than ordinary elegance and overcomes the awkwardness of appearance inseparable as a rule from buildings located on such sites. The absence of the conventional cornice, with its top-heavy, overhanging effect on such tower-like edifices, and the substitution for it of an ornate roof-line, on which the arms of the city of New Amsterdam conspicuously figure, lends originality to the exterior of the edifice without impairing its dignity. The efforts at elaboration have been wisely confined to that portion of the structure that is within range of the pedestrian's vision and are, however, calculated to enhance, where they do not actually impart the effect of solidity. In the entrance, the decorative ability of the designers, Messrs. Herts \& Tallant has found full scope. The relief panels in the foyer, depicting scenes from familiar dramatic stories and life in the New Amsterdam of our forefathe:s, have been vigorously and artistically treated, more especially the "progress" panel, over the doorway to the auditorium, of which Mr. St. John Issing was sculptor, displaying notable merit. Not for a moment, however, has the useful side of the situation been lost sight of, the foyer, staircases and corridors are roomy, direct and unobstructed, as well as profusely ornamented. In the auditorium, the individuality of taste Messrs. Herts \& Tallant have displayed, has found full sway and color, relief work, metal work, furnishings, lighting and upholstering, have each been made subordinate to the general purpose in the production of a tout ensemble of exceptional richness and beauty. The proscenium arch at once compels attention, owing to its freedom from the colunns and entablatures that ordinarily encumber the view of the stage from the boxes and the sides of the house. The disposition of the boxes, with their balconies en corbeille is both picturesque and unique, besides being contributary to the improvement of the point of view of the occupants. The superb decorative picture, over the proscenium arch, by Messrs. Blum \& Wenzell, and the panels above the boxes, of which we present illustrations, are visible from all parts of the house and allegorically interesting, accord admirably in their originality of motif and beautiful execution, with the surrounding details and serve to set them off in place of detracting from them. The New Amsterdam Theatre is moreover unique as regards the comfort and thoughtfilly and ingeniously planned accommodations it provides for its patrons. The ladies' boudoir is certain to elicit the admiration and approbation of the gentler sex, the main feature of its decoration, beautifully worked out, being the tea-rose, while the arrangements offer something altogether surpassing in elegance and convenience the ordinary retiring room. For gentlemen there is a roomy, well-ventilated and readily accessible smoking room, furnished in comfort and elegance, the decorations in allegorical and figure subjects, being notably artistic and interesting. The arrangements for the lighting, heating and ventilation of this most elegant of New York's playhouses, are on a par with its ornamentation, the lighting devices especially being skilfully designed and distributed so as to reveal and enhance the beauty of the artistic color and relief work. Notably handsome and effective are the great pendant lanterns, in foyer and corridors, with their unique color effects. Nor have provisions for the safety of the audiences been overlooked. The building is in every modern respect fire-proof, while ample exits provide safe and easy means of egress in case of emergency. 


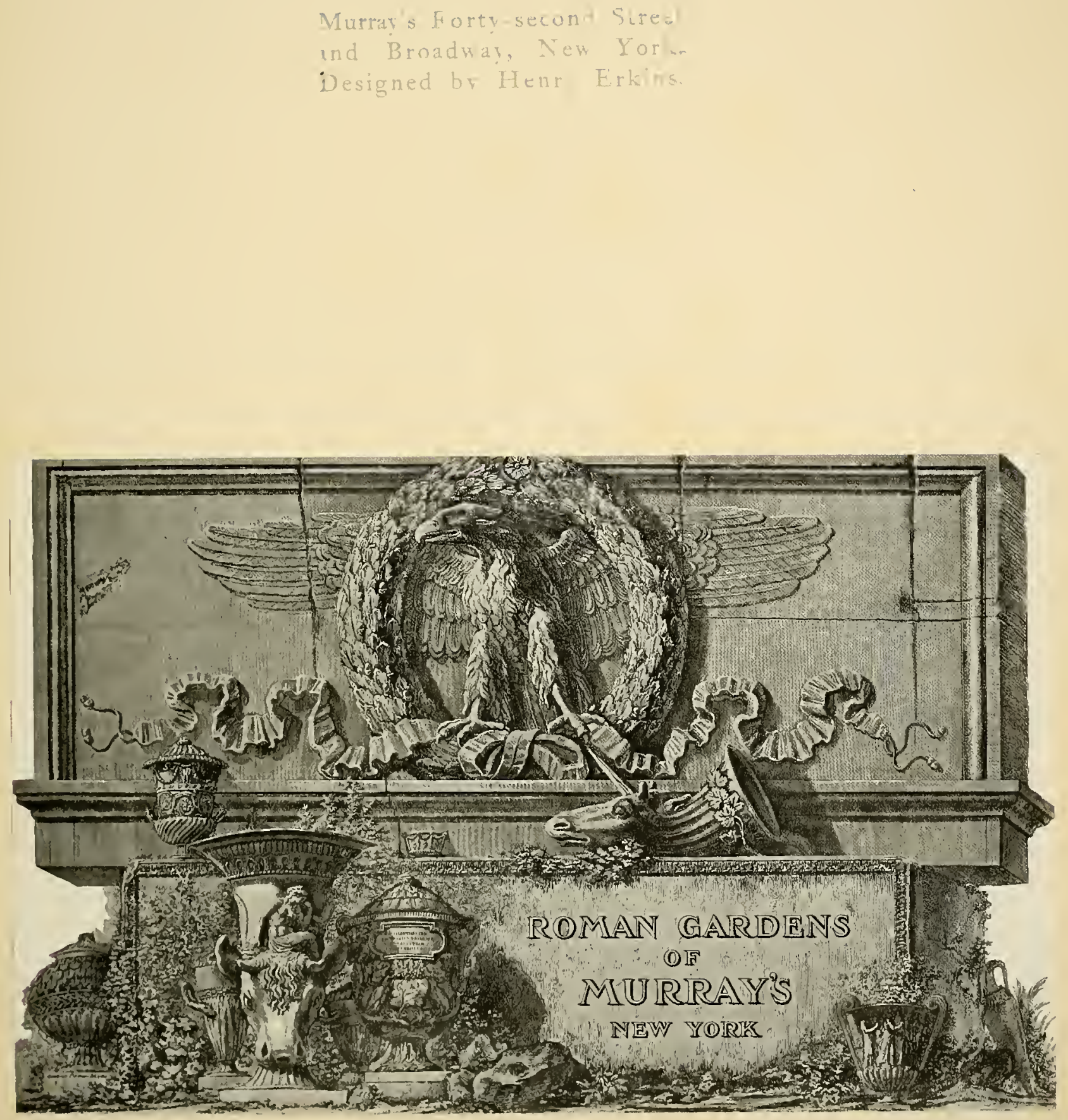

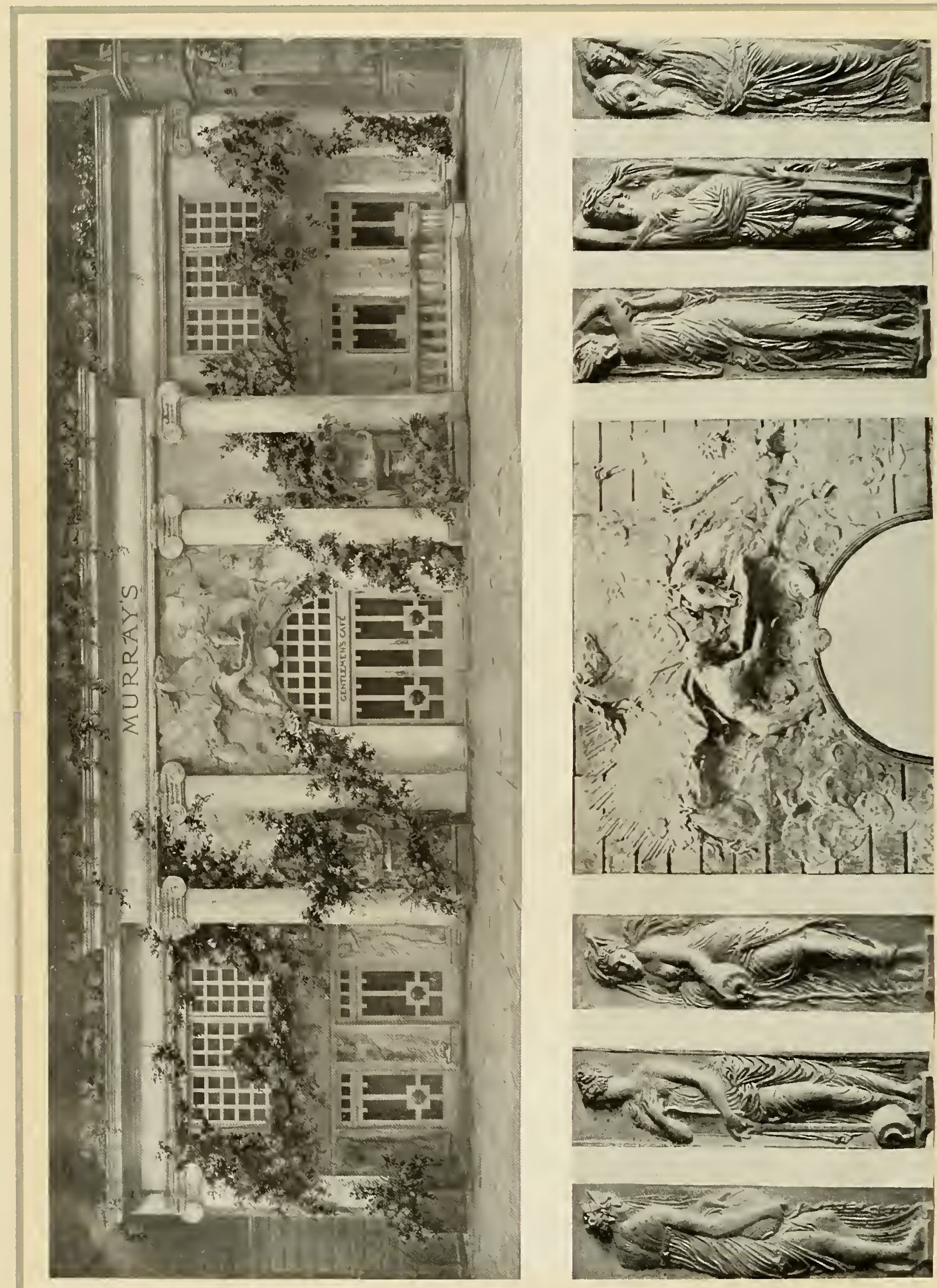


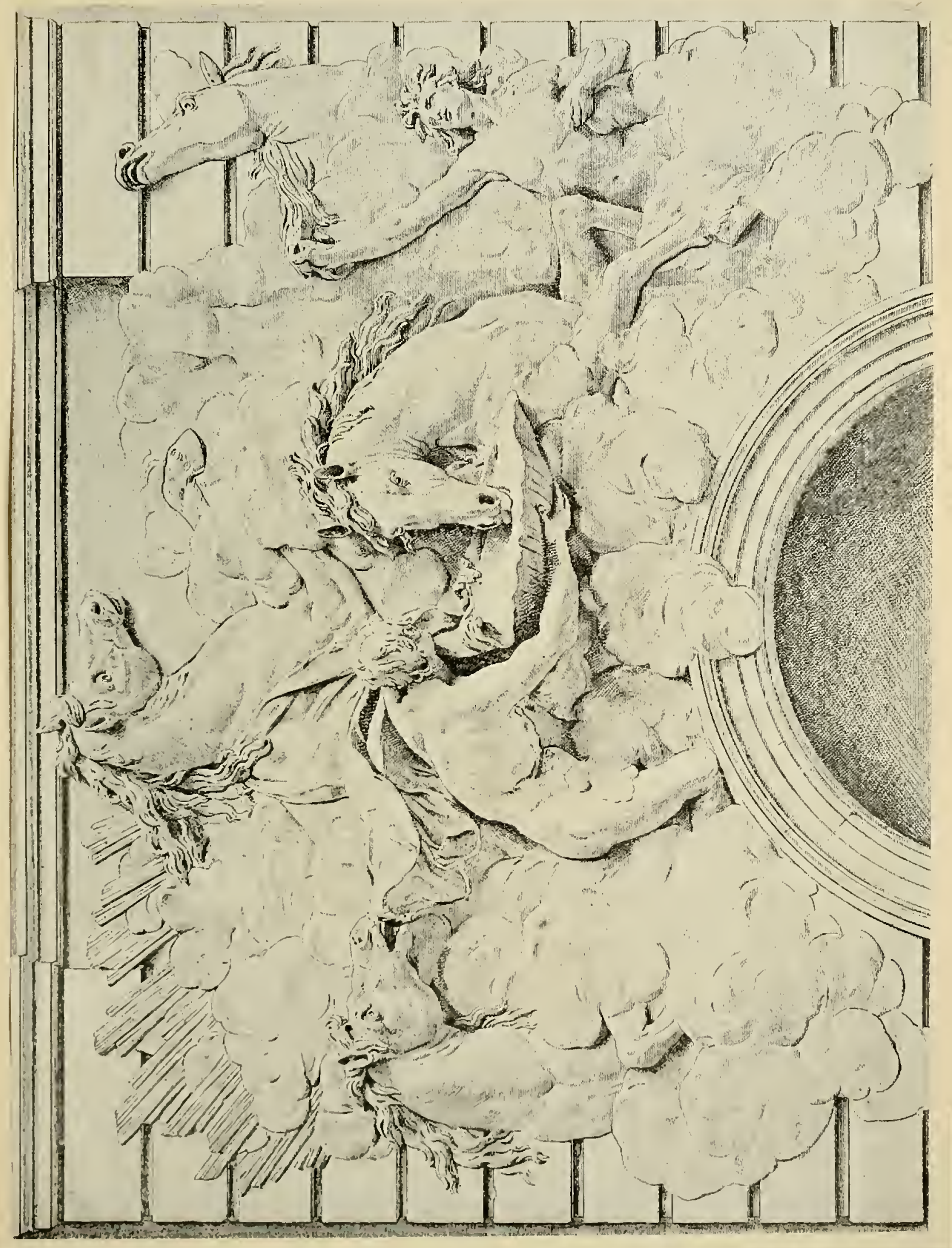




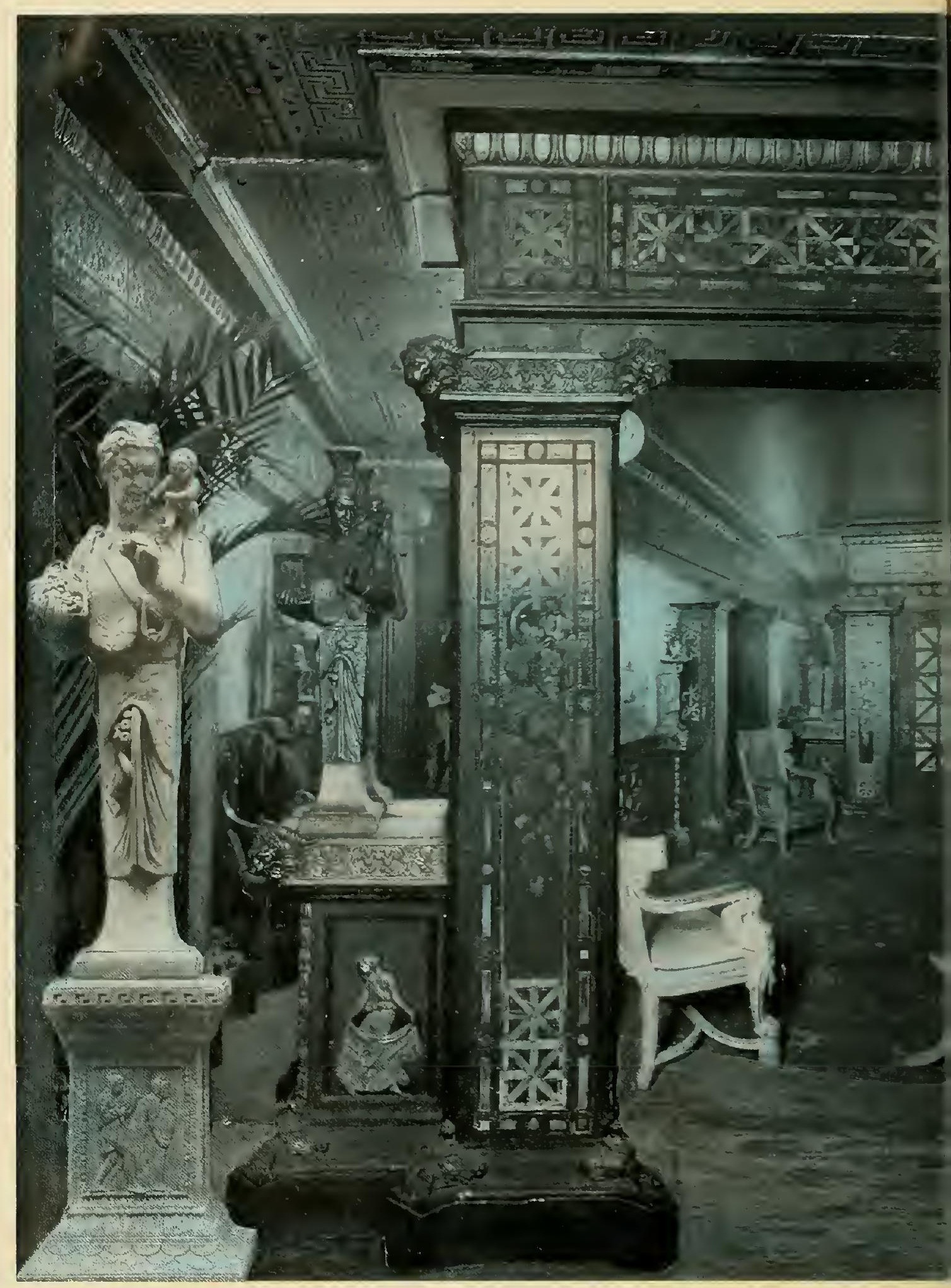





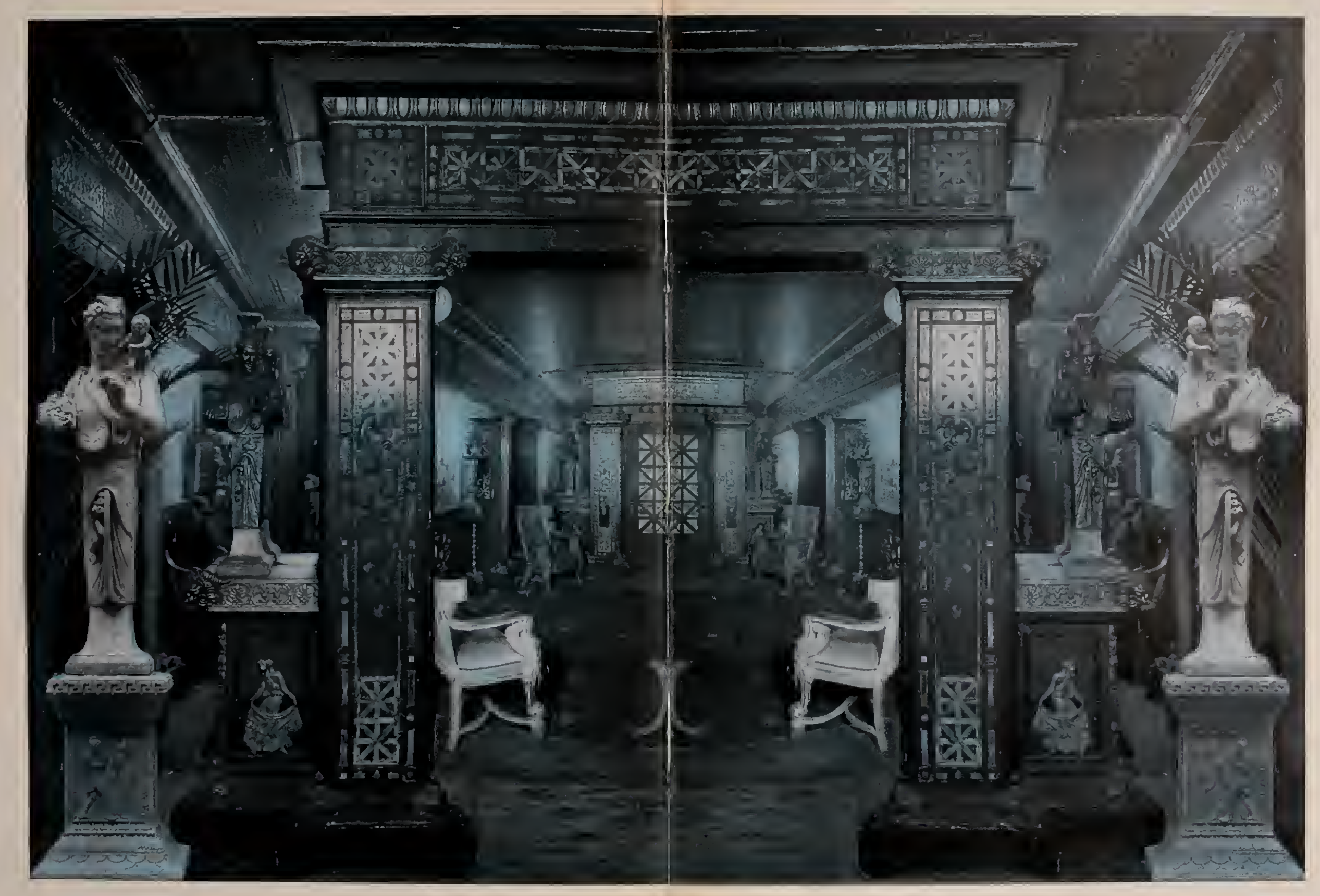



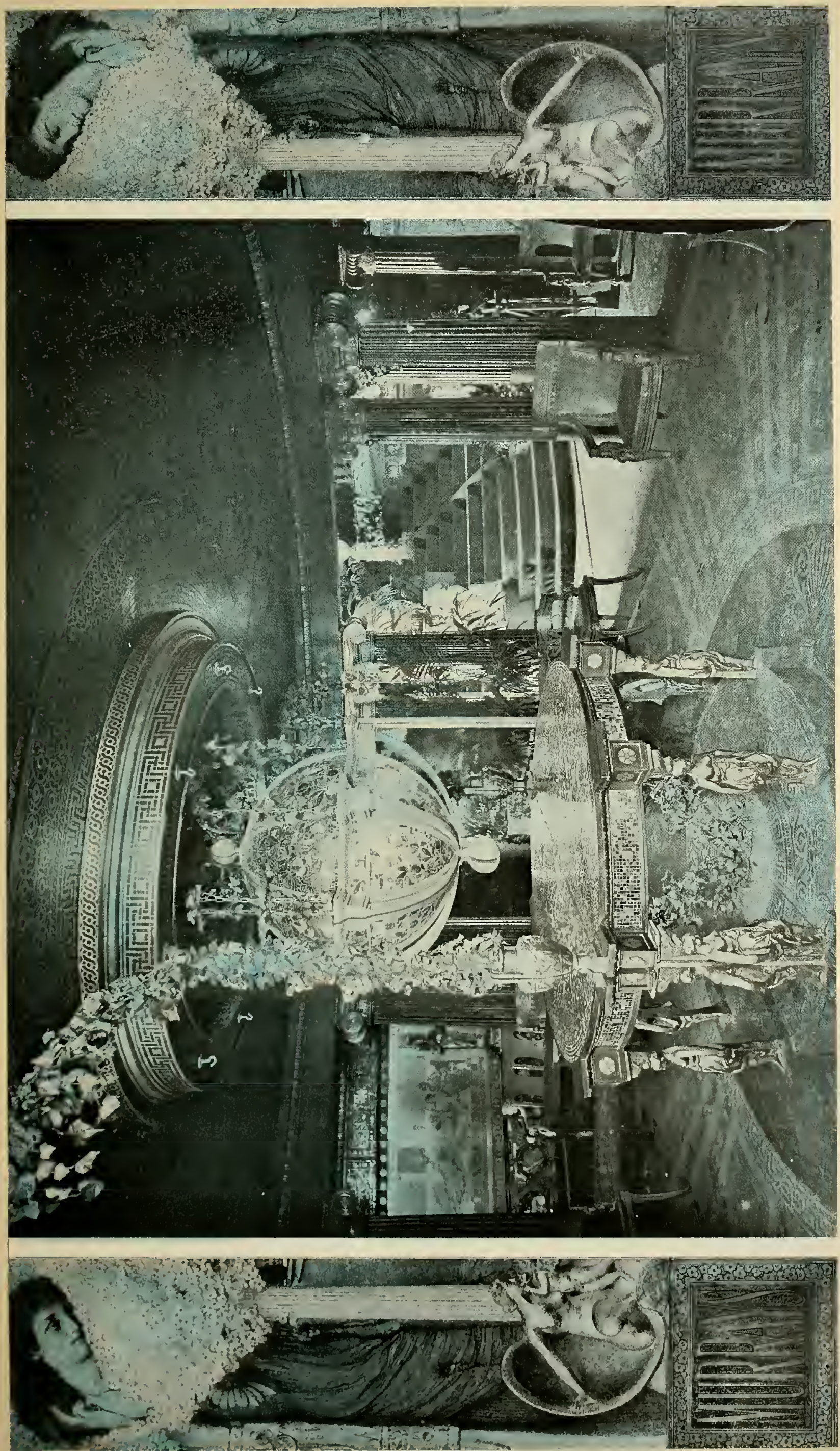

$\mathrm{N}$ our preceding brief description of the theatre we have endeavored to depict a place of amusement embodying the most advanced ideas in refined, latter-day art, or rather the latest evolution of the art of past ages, as applied to the creation of a veritable modern place of recreation. But while New York can offer so beautiful an example of modern or modernized art, it is also possible, within the limits of this youngest of the world's metropoli, to become familiar with the beauties of ancient art in their original form and our next recital will describe the realistic reproduction, largely from the originals in the form of direct copies, casts, etc., of the decorative features of the homes of one of the most lavishly luxurious of the world's ancient peoples-the Romans of the Cæsarean periodas adapted to the embellishment of a modern place of entertainment, the reconstruction, from original models and authentic records, of the artistic splendor and ornate surroundings of a Roman residence, at the period of the Imperial city's greatest opulence and magnificence, all for the pleasure and delectation of the people of the one city in the new world, where such luxury and elegance are likely to find appreciation. To realize, by actual observation, the sumptuous elegance with which, in the palmiest days of their wealth and power, the opulent Romans of old and their precursors and cotemporaries in Egypt and Assyria surrounded themselves, it is not necessary for the New Yorker to visit the exhumed ruins of Pompeii, the excavations made on the sites of ancient Nineveh or Babylon, or the palm-fringed banks of old Nile. At his very doors, in the center of the city's theatre and hotel section, within a stone's throw of the theatre above described and within earshot of the shriek of the noisy iron horse, he can be transported as though on the famous carpet of Mahomet, back into ancient Rome and can feast his eyes on an artistic and authentically exact reproduction of the most beautiful features of Rome's most ornate homes, of the palaces, villas and pleasure resorts of her wealthiest and most cultured citizens, such as Bulwer Lytton so entrancingly describes in his descriptions of Rome and Pompeii. The Roman Garden of Murray's, 228 to 232 West Forty-second Street, between Seventh and Eighth Avenues, brings back to us the conditions and surroundings that made the name of ancient Rome synonomous with artistic taste and unrivaled elegance, the storehouse for all that was precious and beautiful in the world that the Romans of old, knew, conquered and plundered. The fact that all the ingenuity of plan, the wealth of artistic elaboration, and the profusion of gorgeous ornamentation, revealed in this unique establishment, has really been "grafted" as it were, on to a building of essentially plain and formal character, planned and erected originally for a purpose absolutely foreign to that for which it is today utilized, lends additional interest to the results achieved and reflects the greater credit on the author and originator of this superb exemplification of modern taste and skill. Henry Erkins, who was constrained to adopt, as the basis for this beautiful production, a building originally planned for use as a schoolhouse, but which the magic wand of Mr. Erkins' genius has transformed so happily that in its present arrangement, equipment, adornment and ormamentation, it nowhere betrays the slightest trace of its original purpose in any way. 

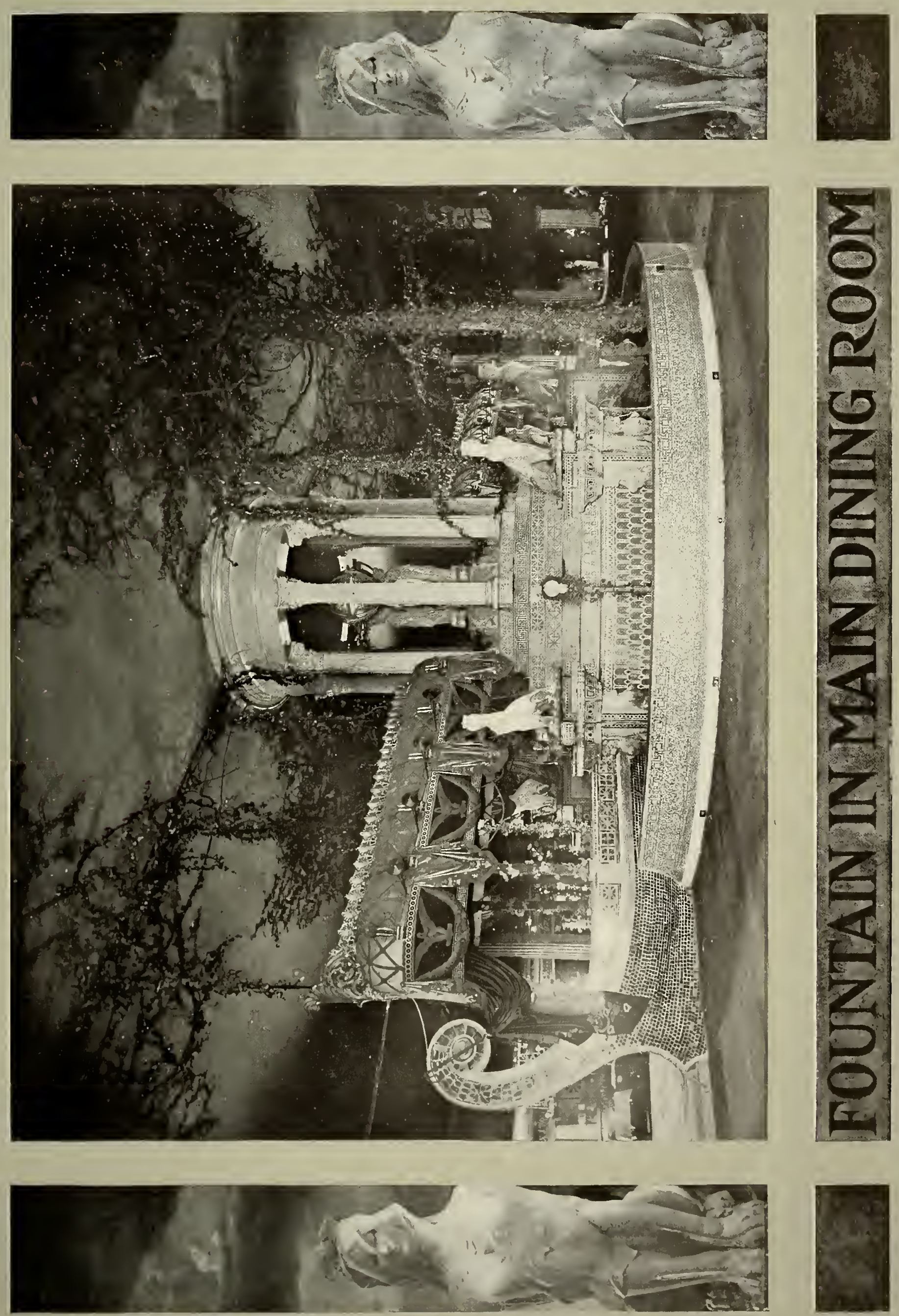

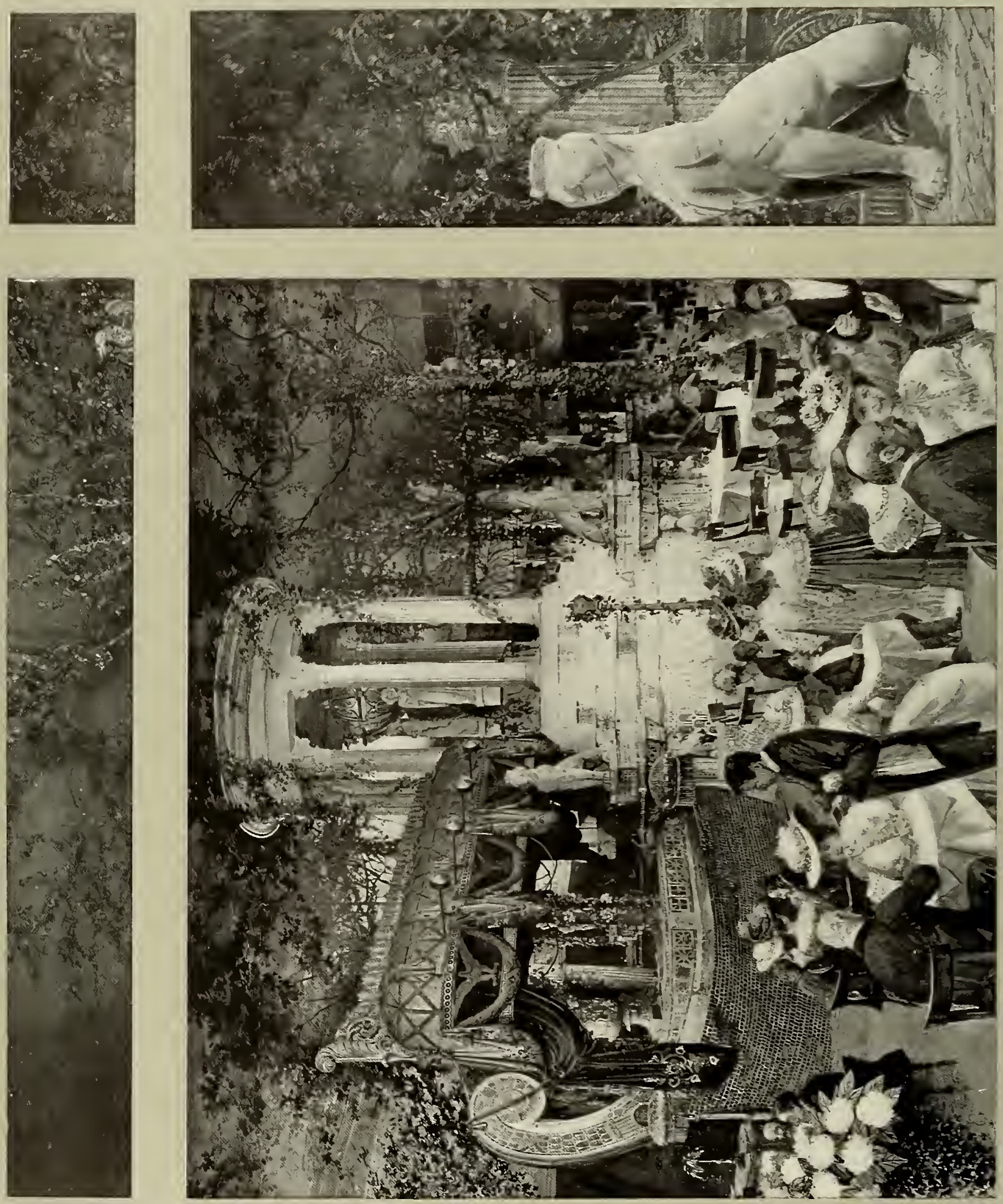

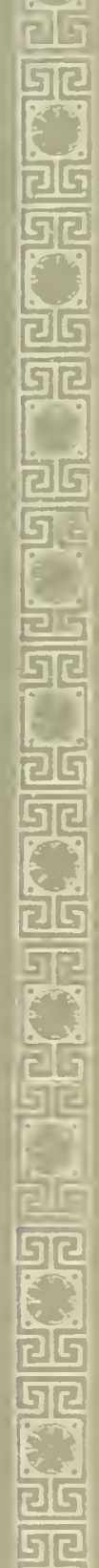
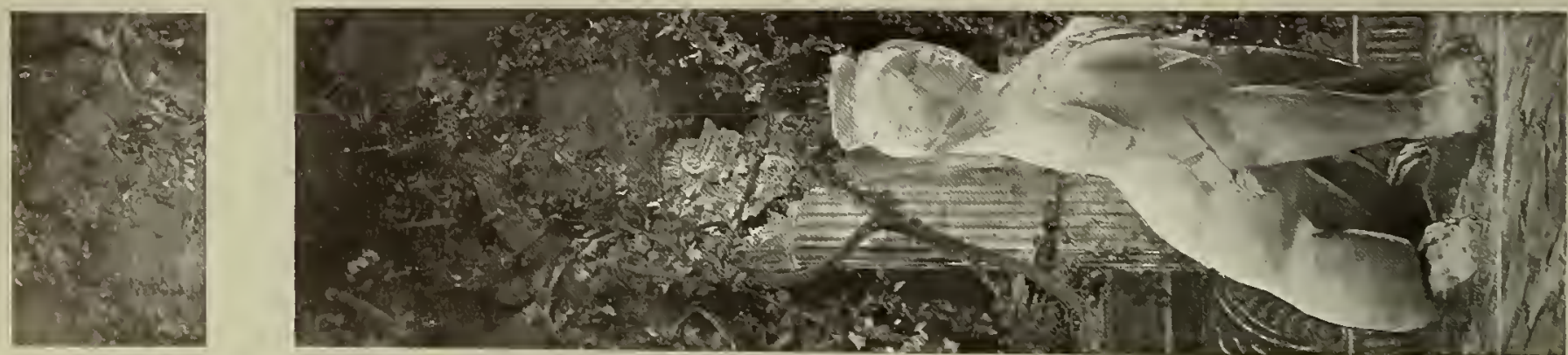

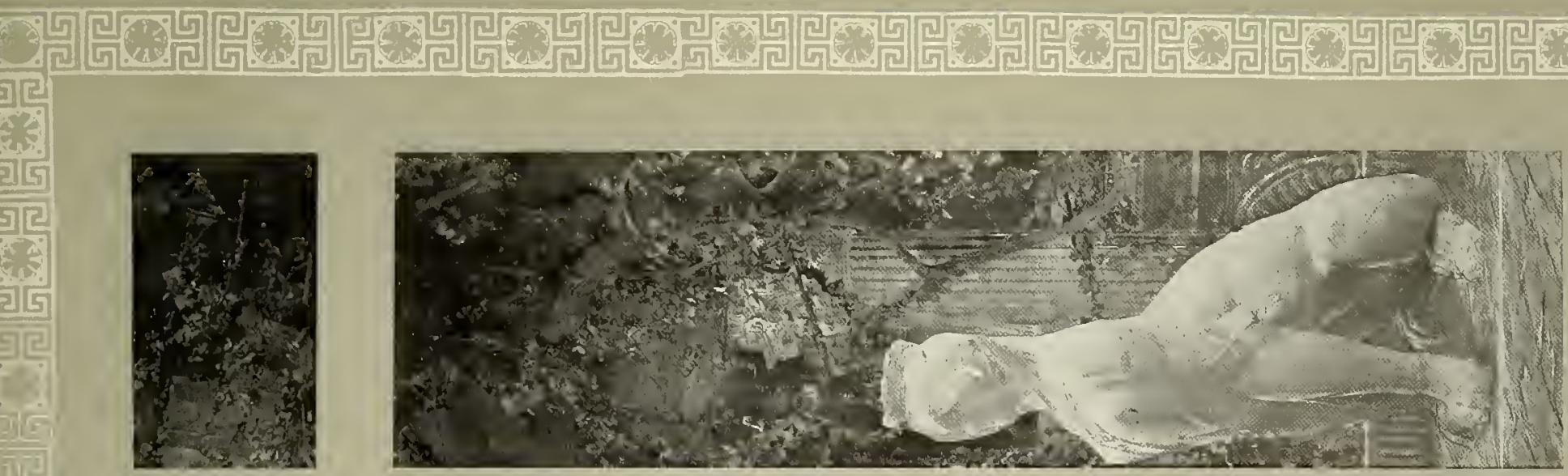

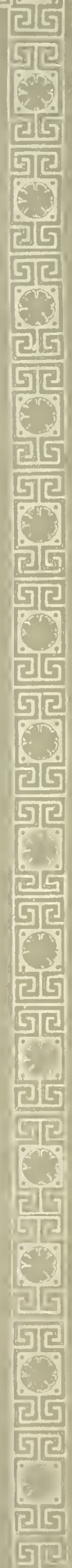
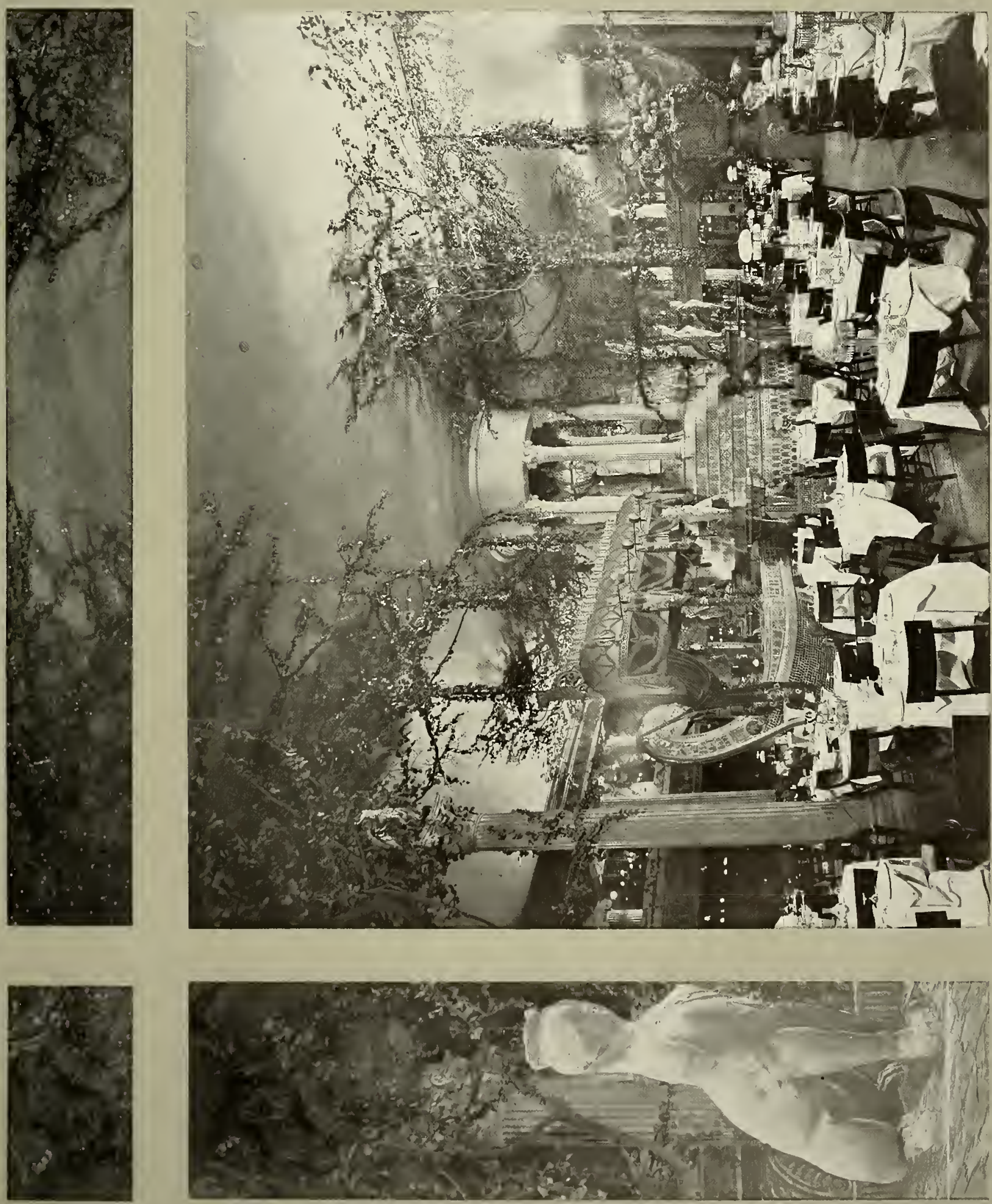


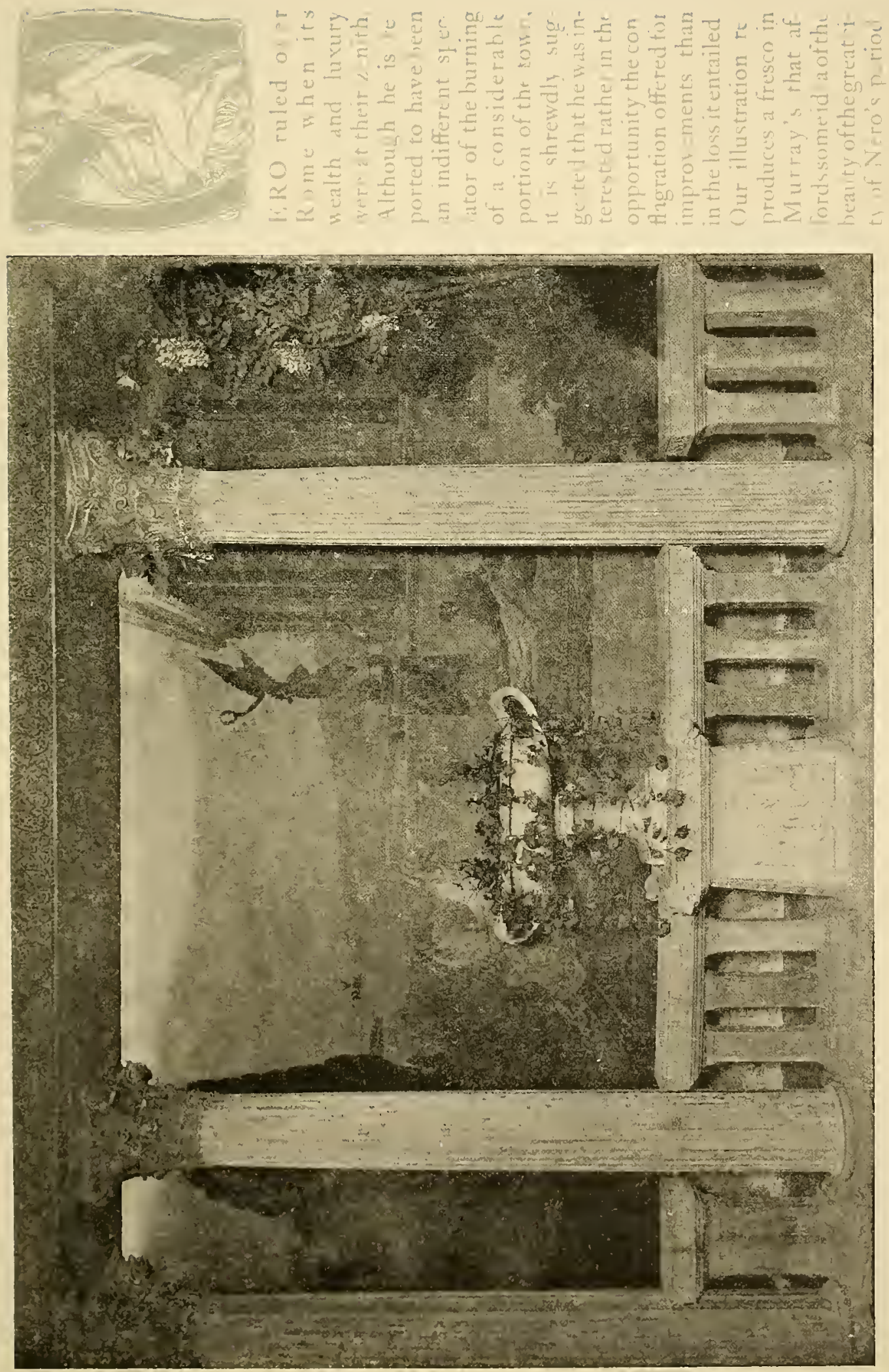

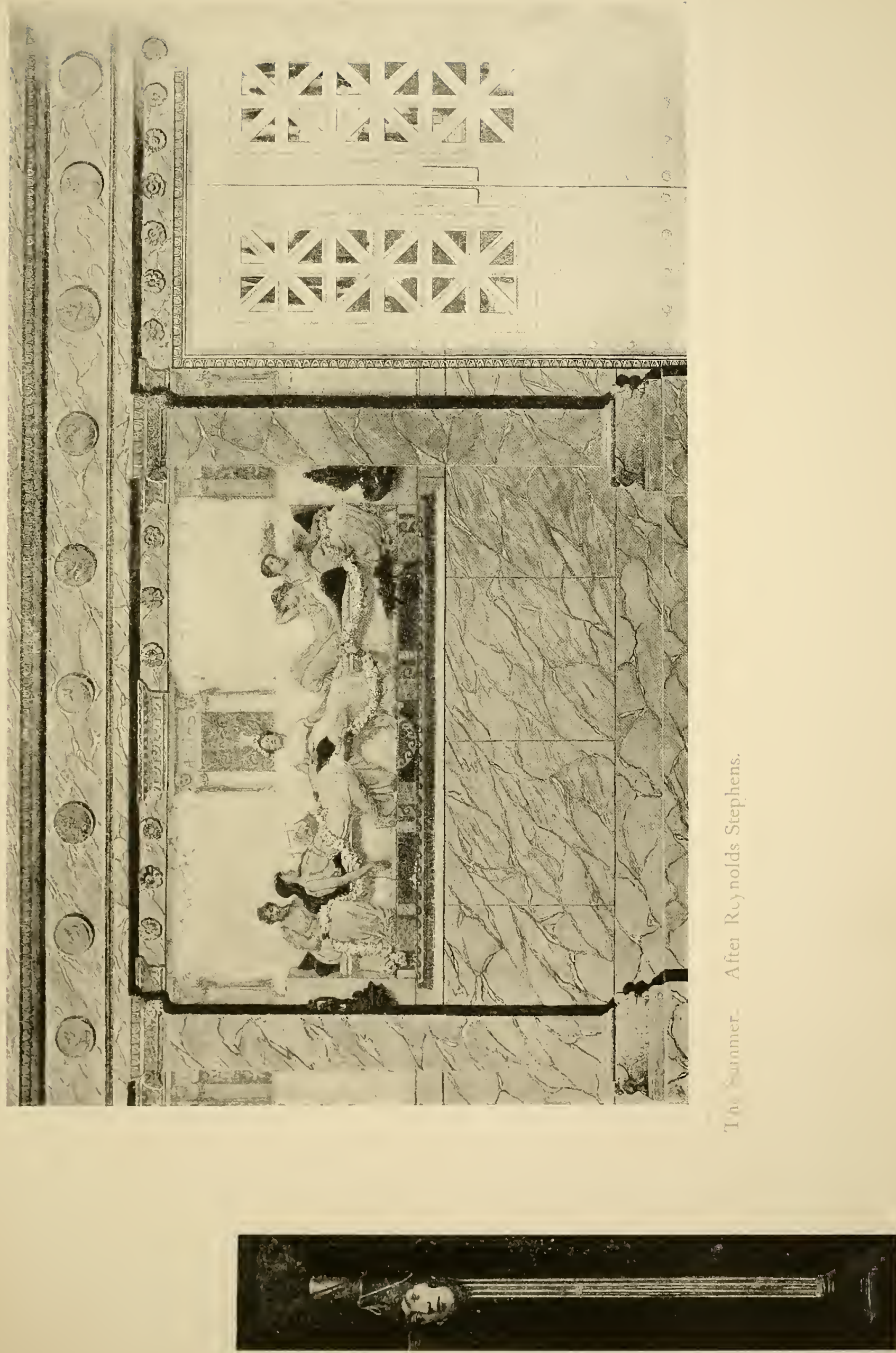


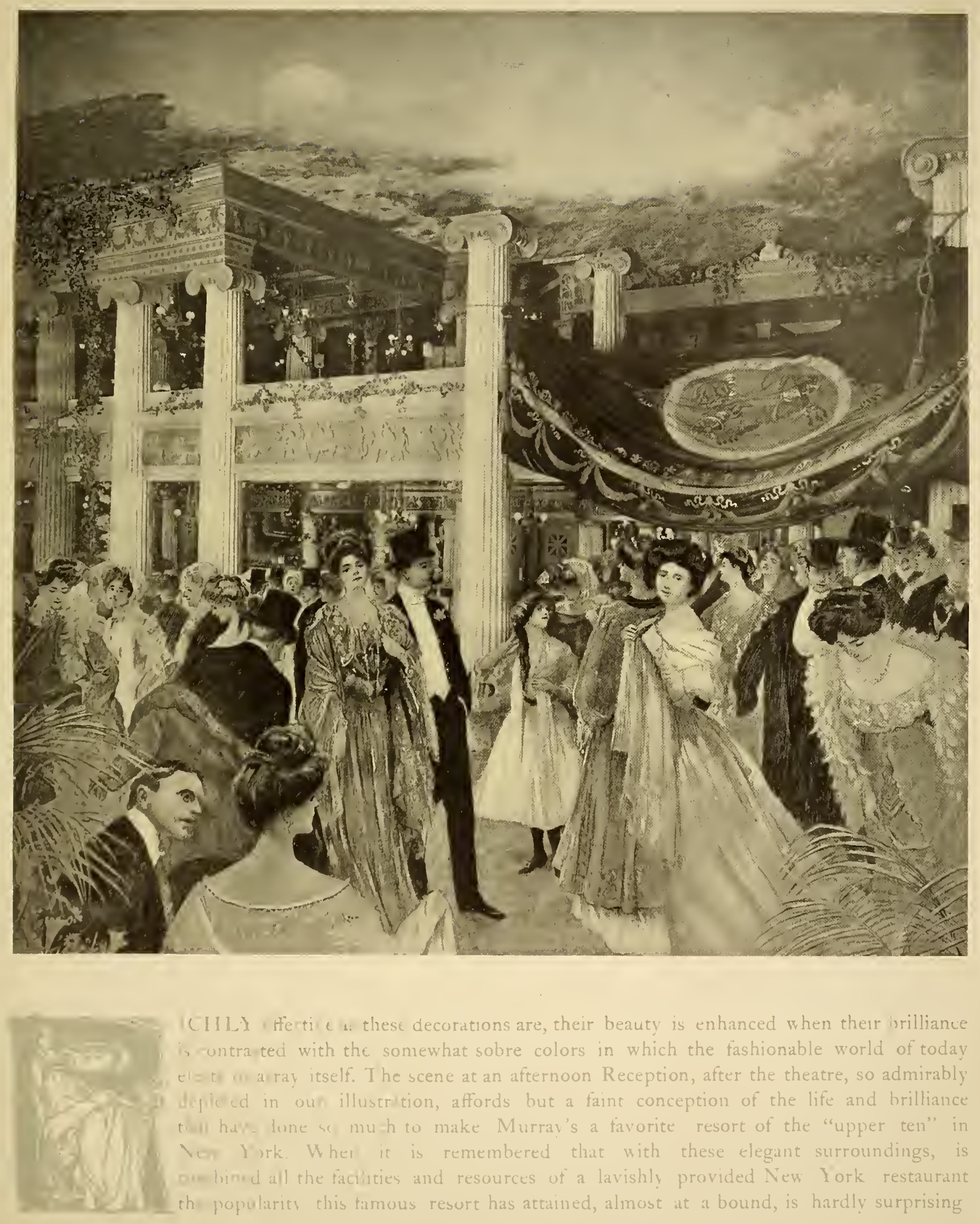



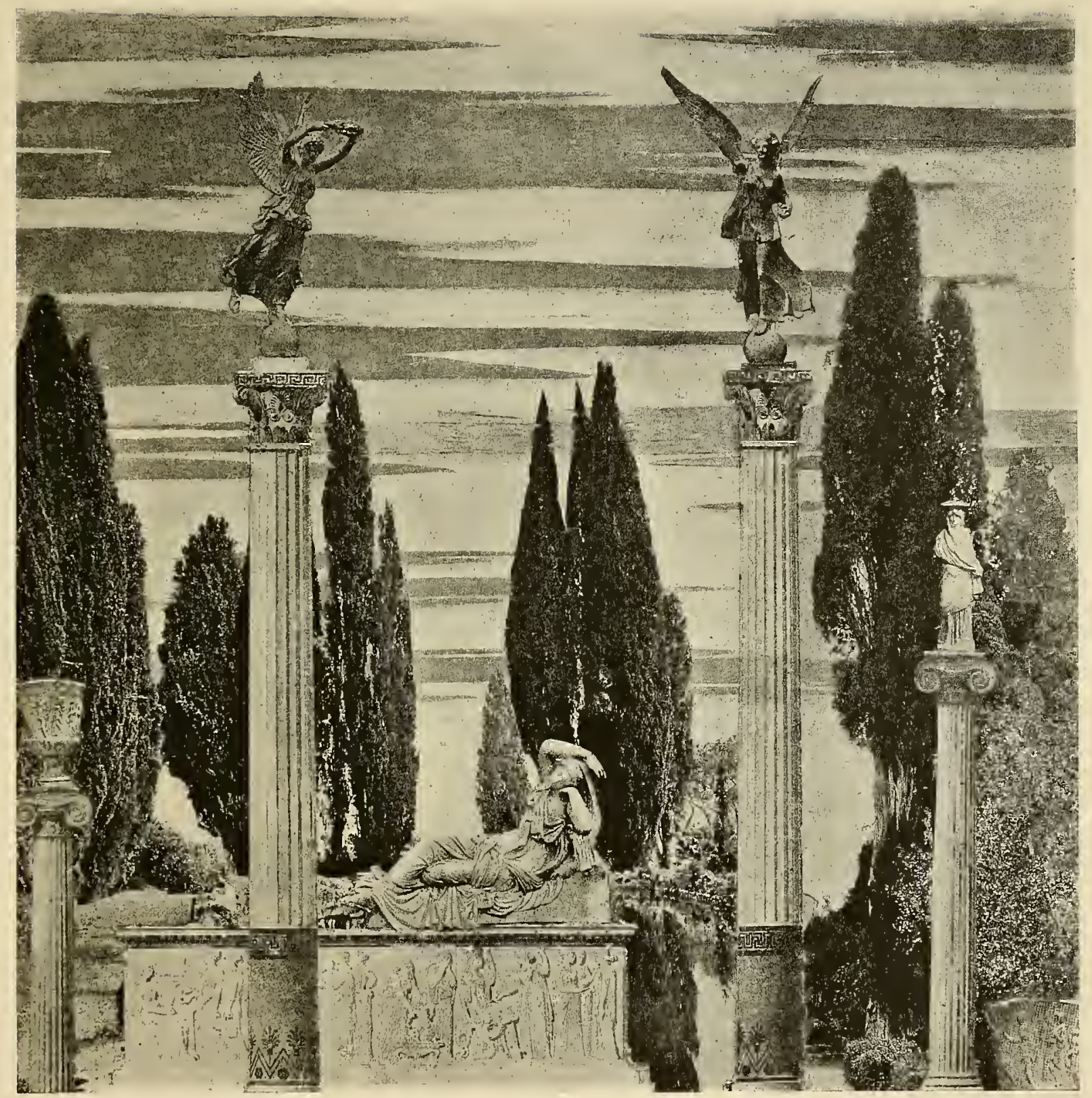

Murray's Gardens 
. 
H
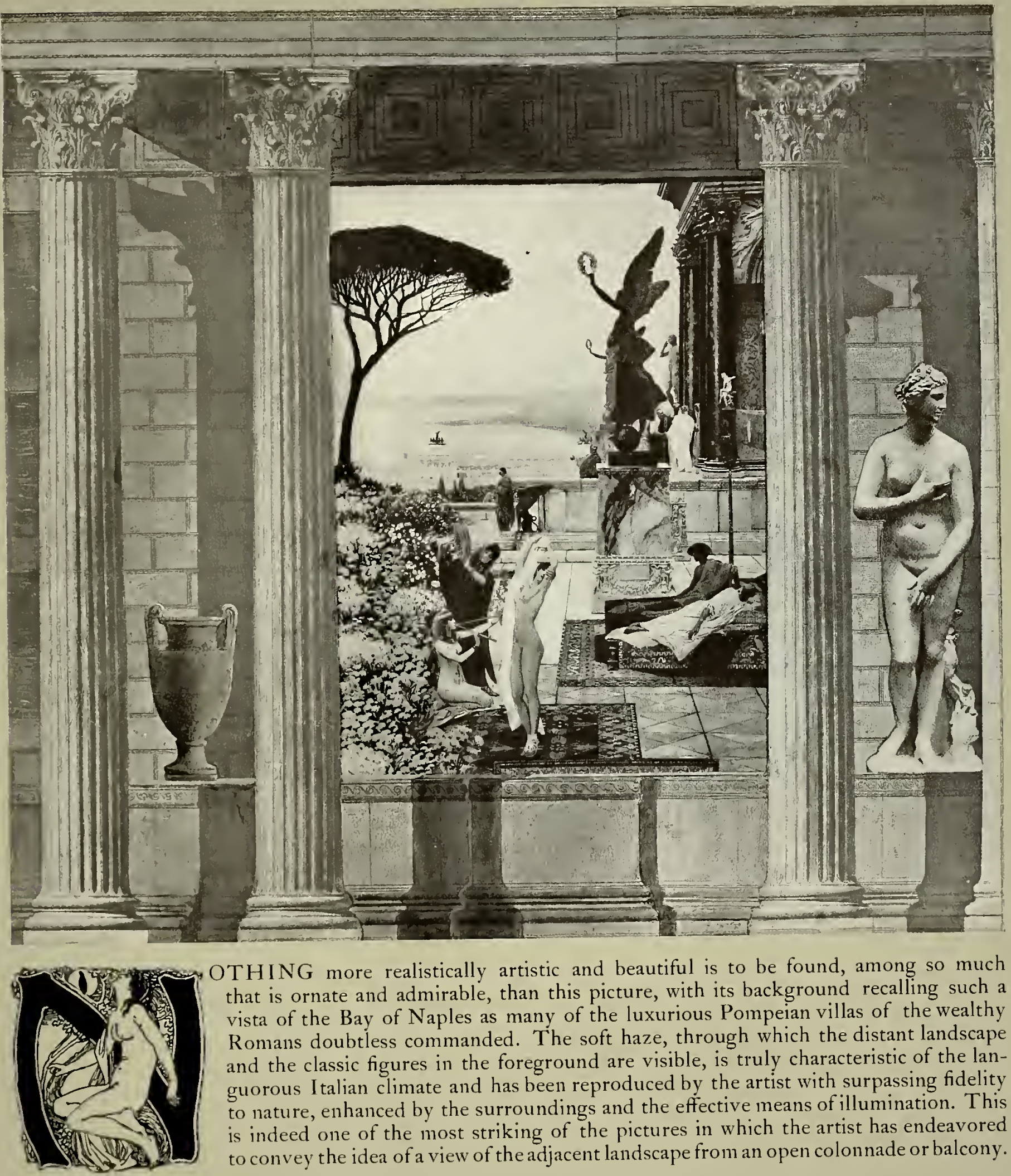

THING more realistically artistic and beautiful is to be found, among so much that is ornate and admirable, than this picture, with its background recalling such a vista of the Bay of Naples as many of the luxurious Pompeian villas of the wealthy Romans doubtless commanded. The soft haze, through whe guorous I talian climate and has been reproduced by the artist with surpassing fidelity to nature, enhanced by the surroundings and the effective means of illumination. This is indeed one of the most striking of the pictures in which the artist has endeavored to convey the idea of a view of the adjacent landscape from an open colonnade or balcony. 


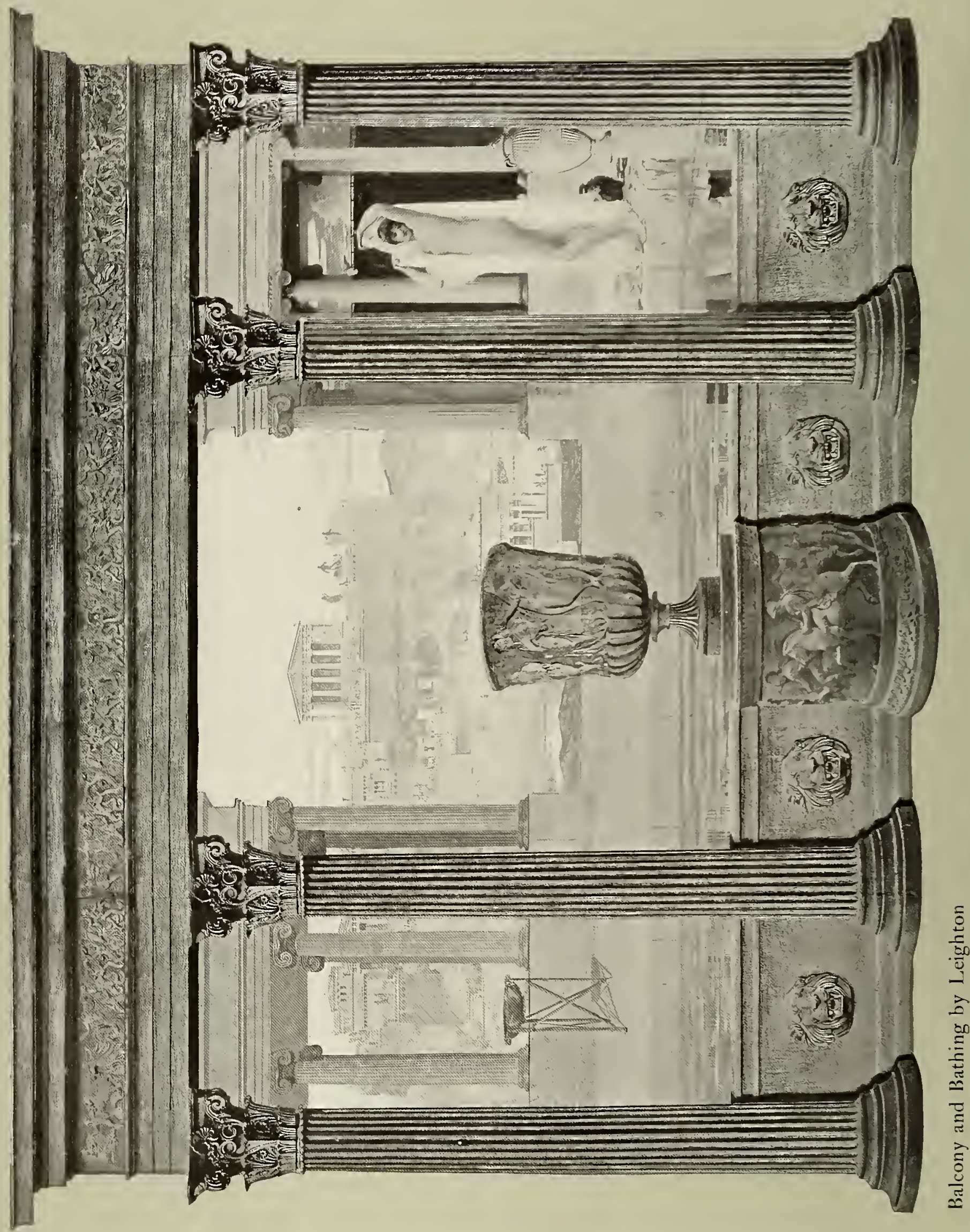



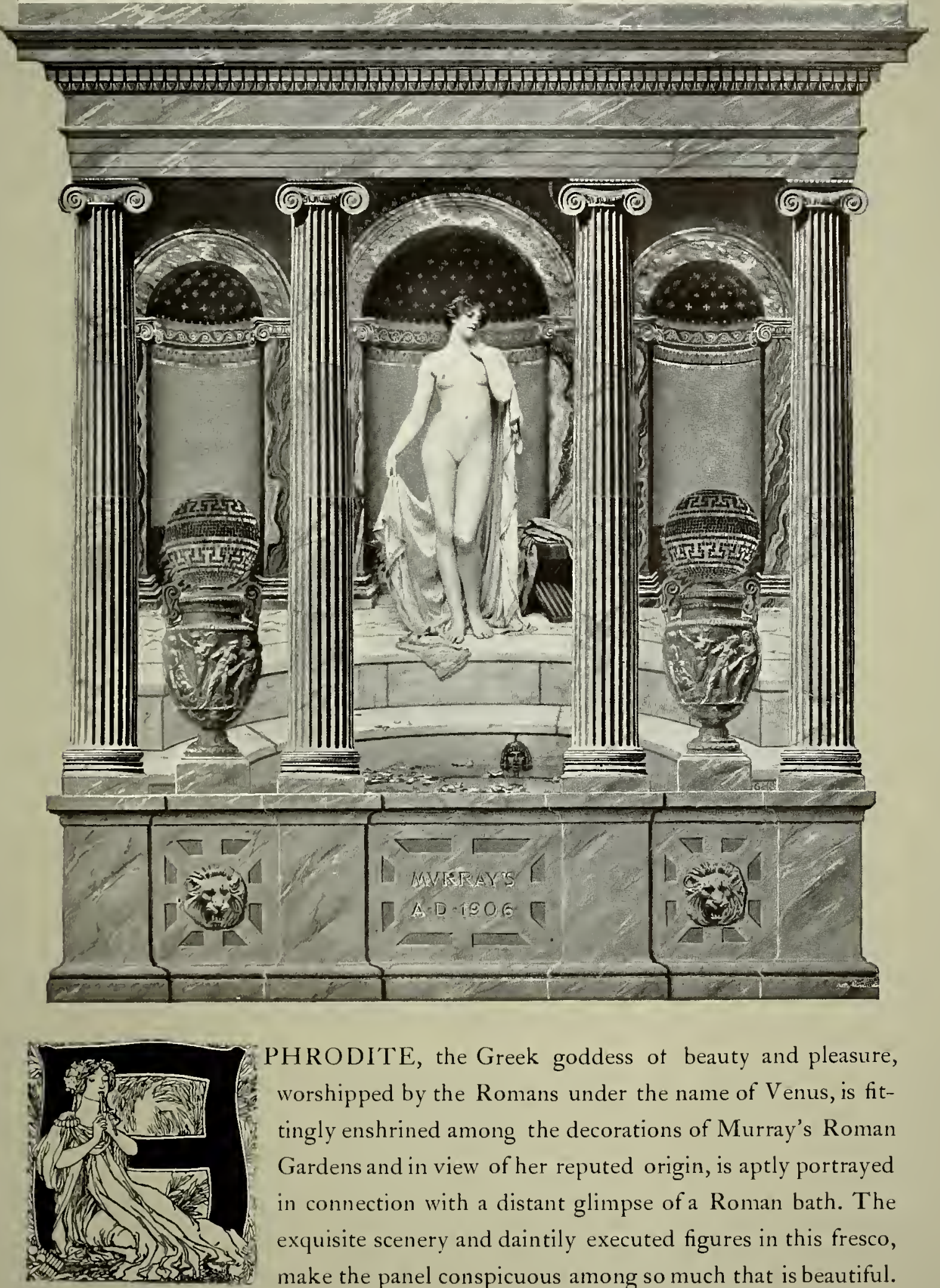

PHRODITE, the Greek goddess of beauty and pleasure, worshipped by the Romans under the name of Venus, is fittingly enshrined among the decorations of Murray's Roman Gardens and in view of her reputed origin, is aptly portrayed in connection with a distant glimpse of a Roman bath. The exquisite scenery and daintily executed figures in this fresco, make the panel conspicuous among so much that is beautiful. 

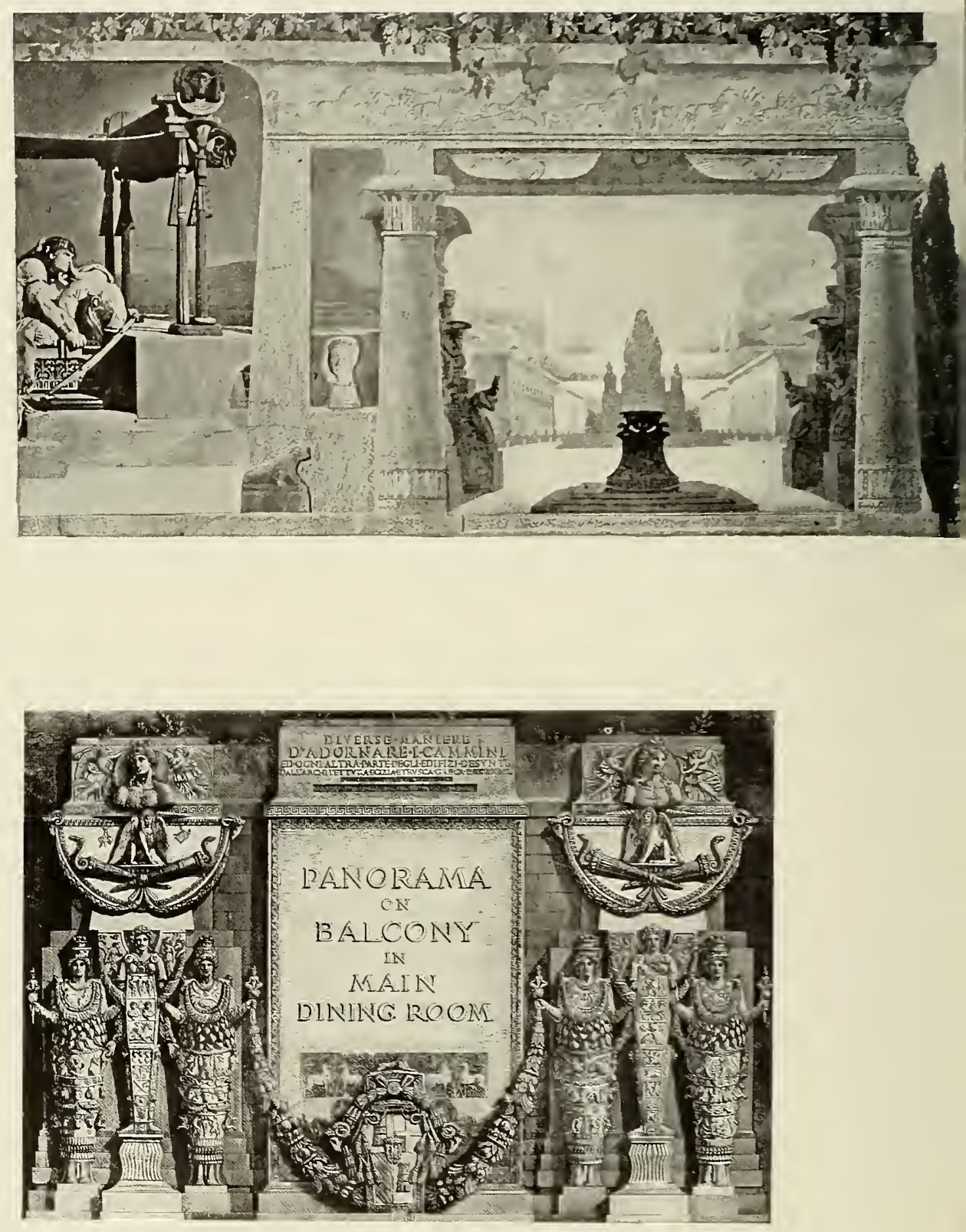

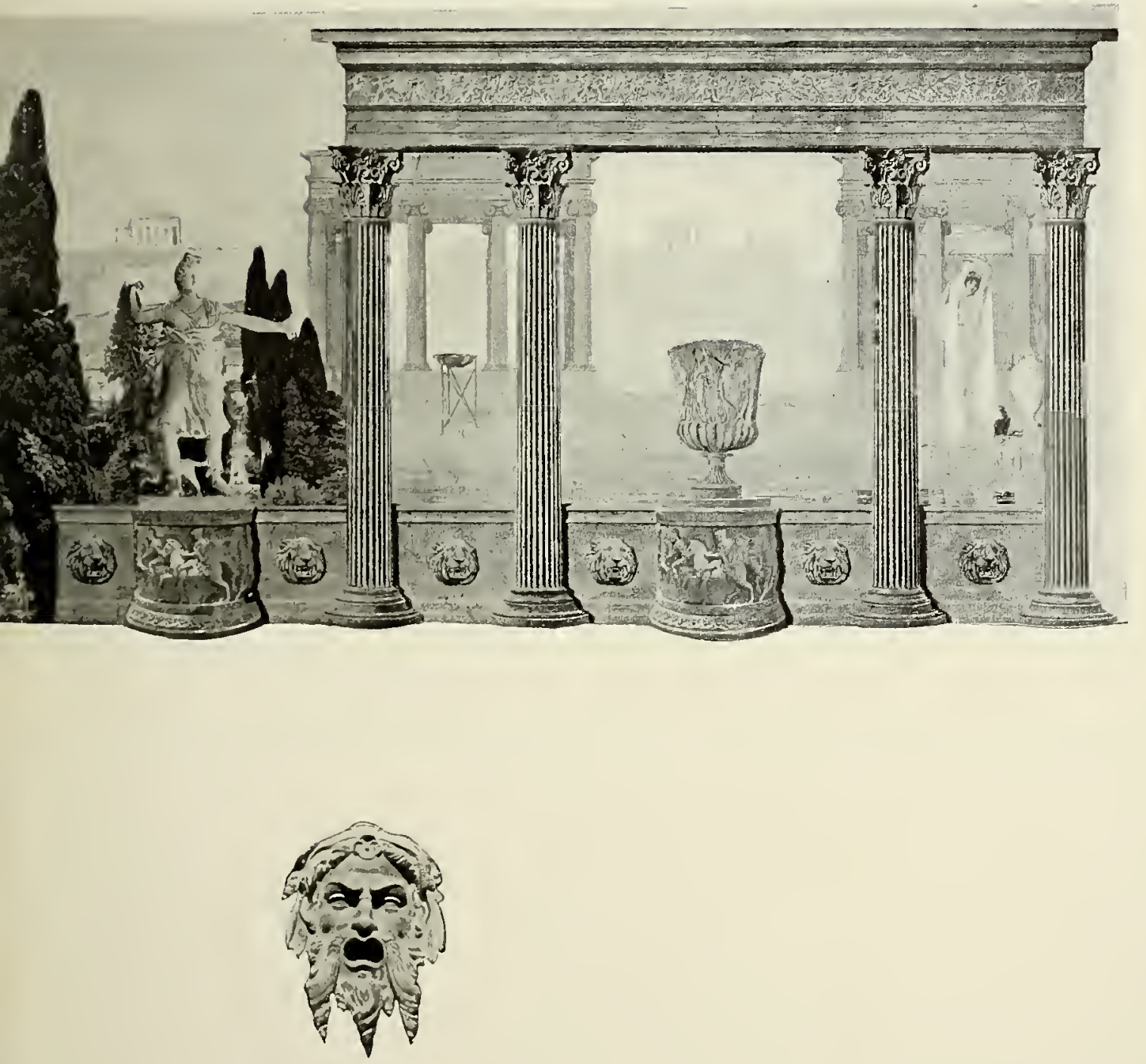


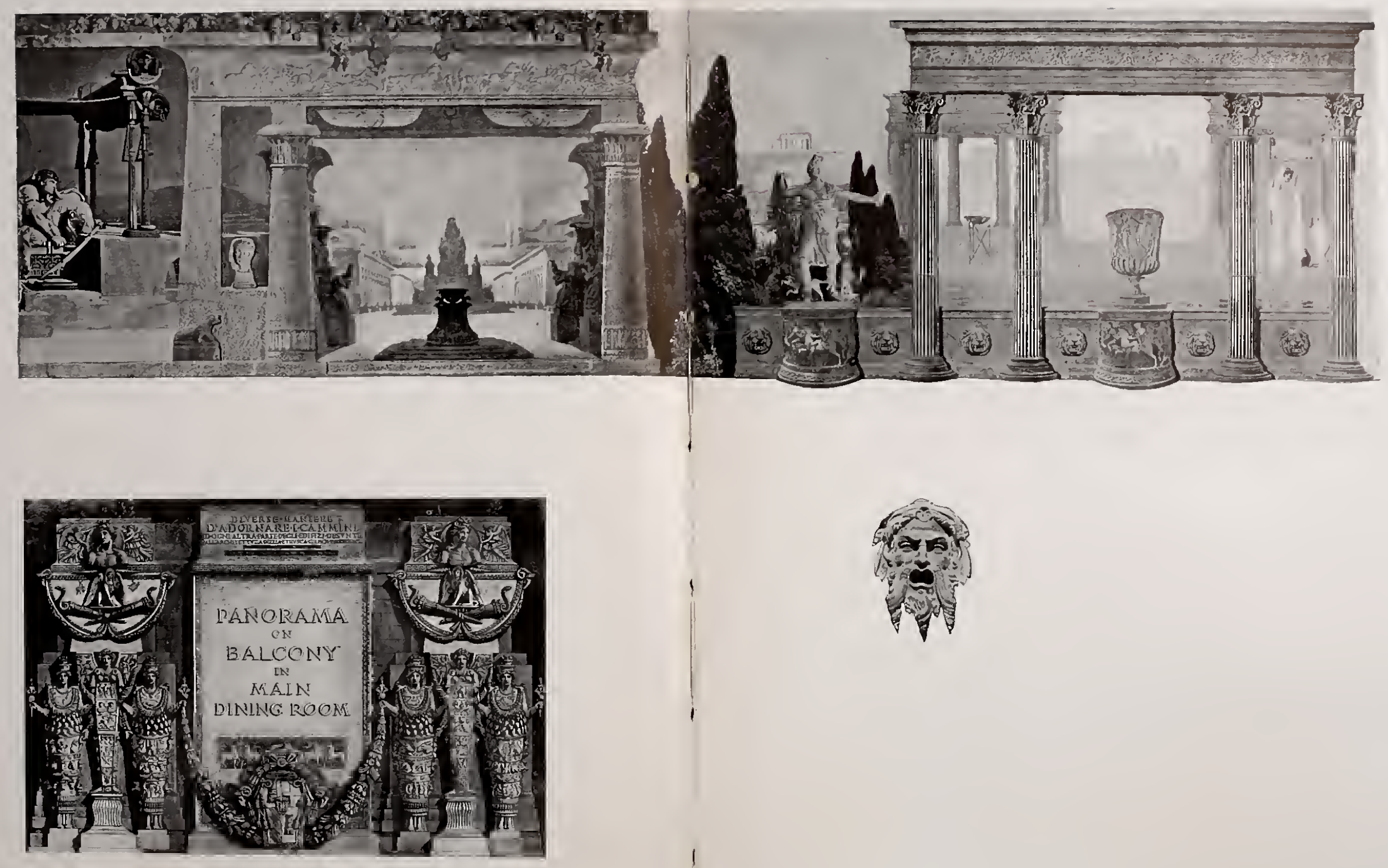
Entering the "Roman Garden" directly from the street, we are translated at once from our prosaic, twentieth century surroundings to the romantic elegance of luxurious Rome. Truly, if this is a representation of the glories of the "city on the seven hills," the proud boast of the Roman, "I am a citizen of Rome," is at once comprehensible and excusable. Take away the scions of the four hundred in their gloomy evening attire, looking like so many scarecrows or undertakers, and the sober-faced attendants, equally sombre as to apparel, and replace them with figures tricked out in the many-hued raiment of ancient days; substitute for the plug-hatted "Jehu" and the begogled chauffeur, the Roman charioteer, and for the blue-coated guardian of the peace on the threshold, the mail-clad Roman legionary, and but for such improvements as we owe to our mechanical progress, the visitor to Murray's might readily imagine himself "turned back" two thousand years to the city of the Cresars, at the zenith of its wealth and splendor, or to one of the replicas of these scenes of luxury that have lent fame and luster to the courts of some of Europe's most extravagant potentates. The exterior of the building, has been remodelled as to its two lower stories in Caen stone, to represent the ancient hotel of Cardinal De Rohan in Paris. Above the main 
doorway is a superb panel showing a number of horses at a fountain with their attendants. This work, entitled "Les Chevaux du Soleil," is reproduced from the original over the doorway of the Rohan palace, and was designed and executed by Robert Le Lorain, who also designed the palace façade. On either side of the entrance to Murray's are three panels representing female figures, reproductions of originals in Jean Goujon's Fontaine des Innocents, Paris. The visitor first enters a reception room or foyer in which the prevailing colors are black and gold, with a colonnade and portico and a handsome marble mosaic pavement. Attention is at once attracted to the mirror effects, by means of which, not only the dimensions of the apartment are very much magnified, but its appointments, really half columns, globes, urns, etc., completed by the reflection of the one substantial half in mirrors, an exceedingly ingenious means of heightening the decorative effects and augmenting the apparent magnitude. From the reception room the "Roman Garden" proper is reached. This, in a Roman residence, would be an open court with a colonnade on each side, and was known as the "atrium." Here, in ancient Rome, banquets were served, and in Murray's the "atrium" is put to a similar use, serving as the main dining room of the establishment. At one end 



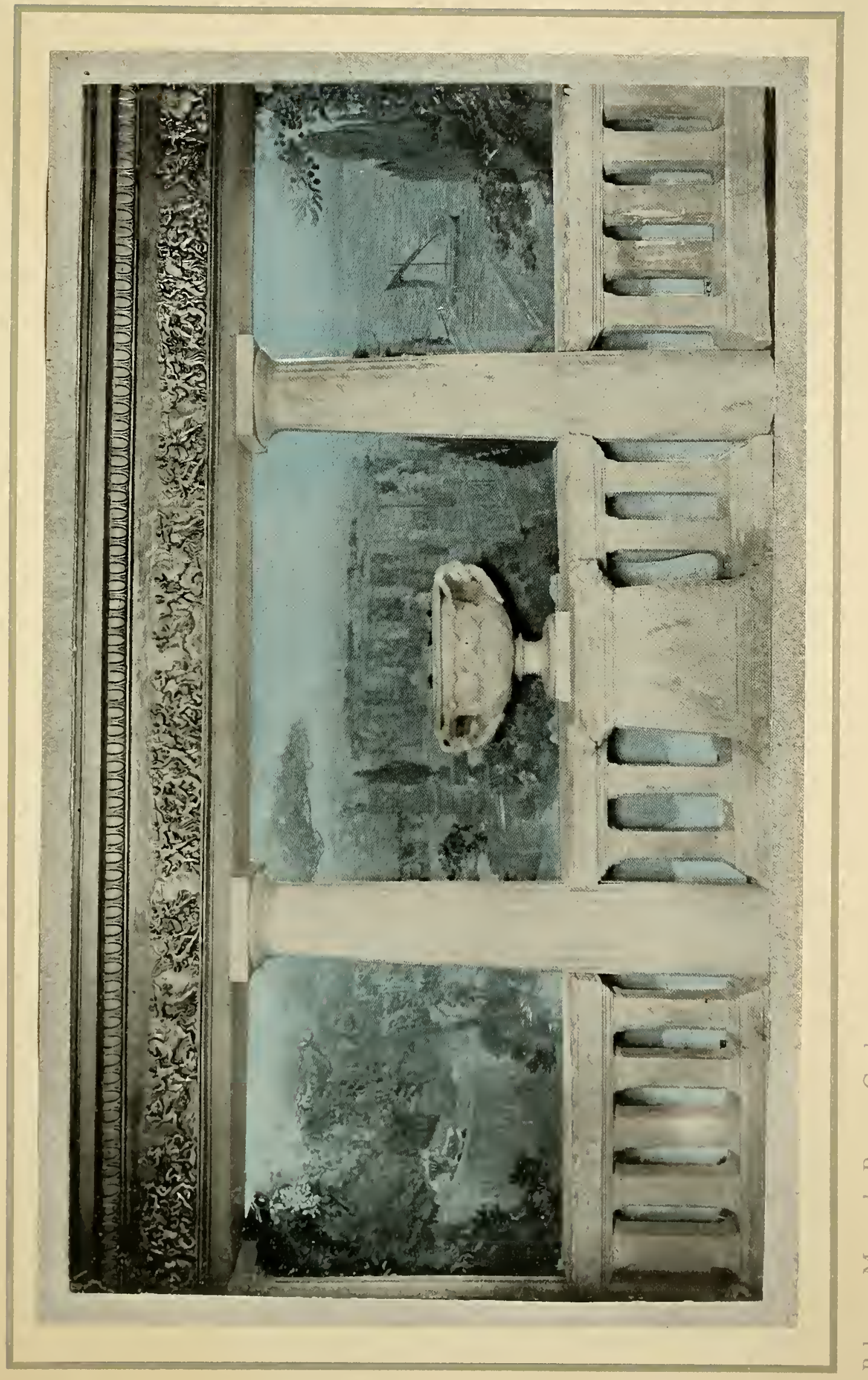

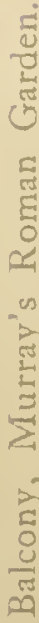




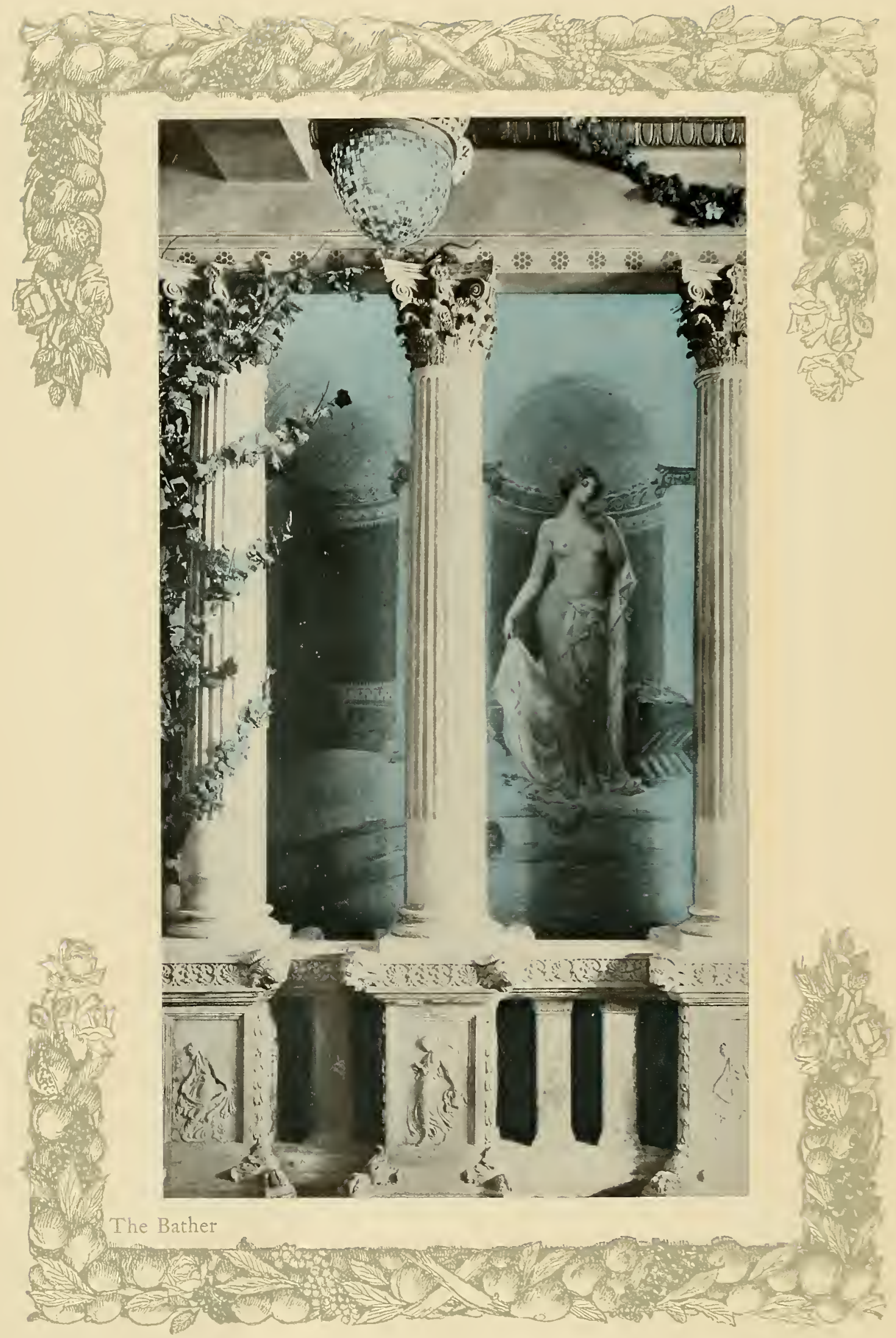




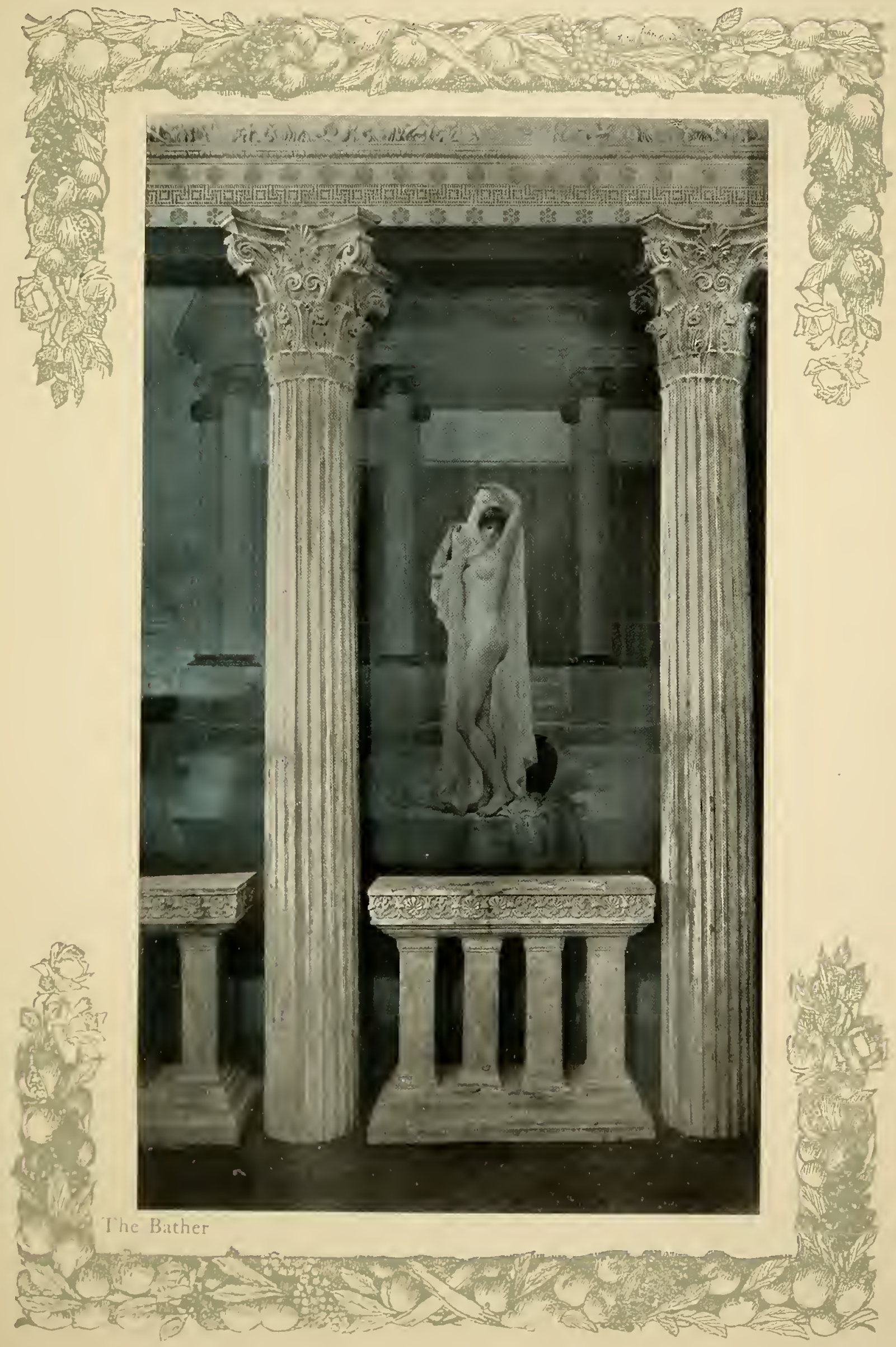



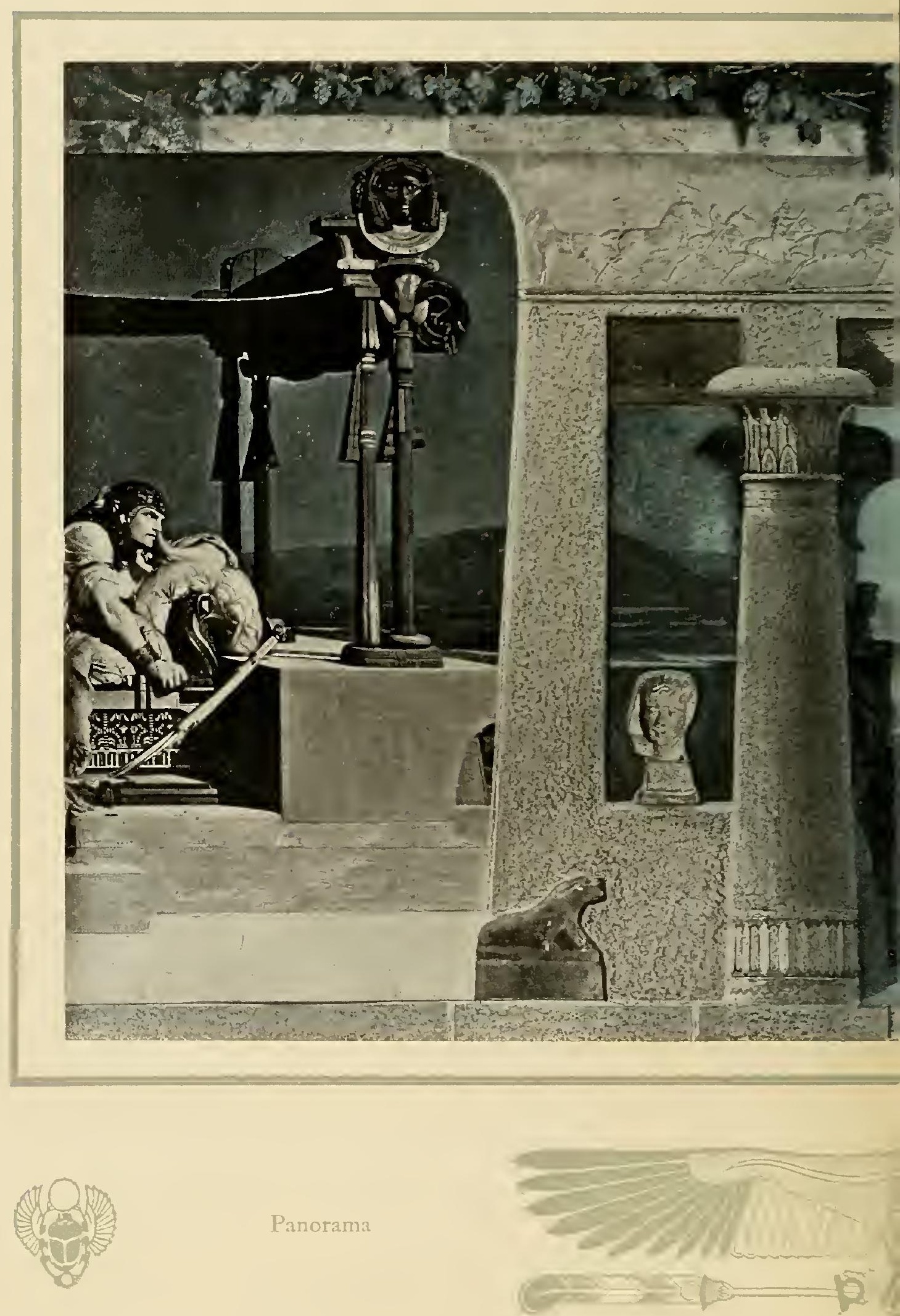


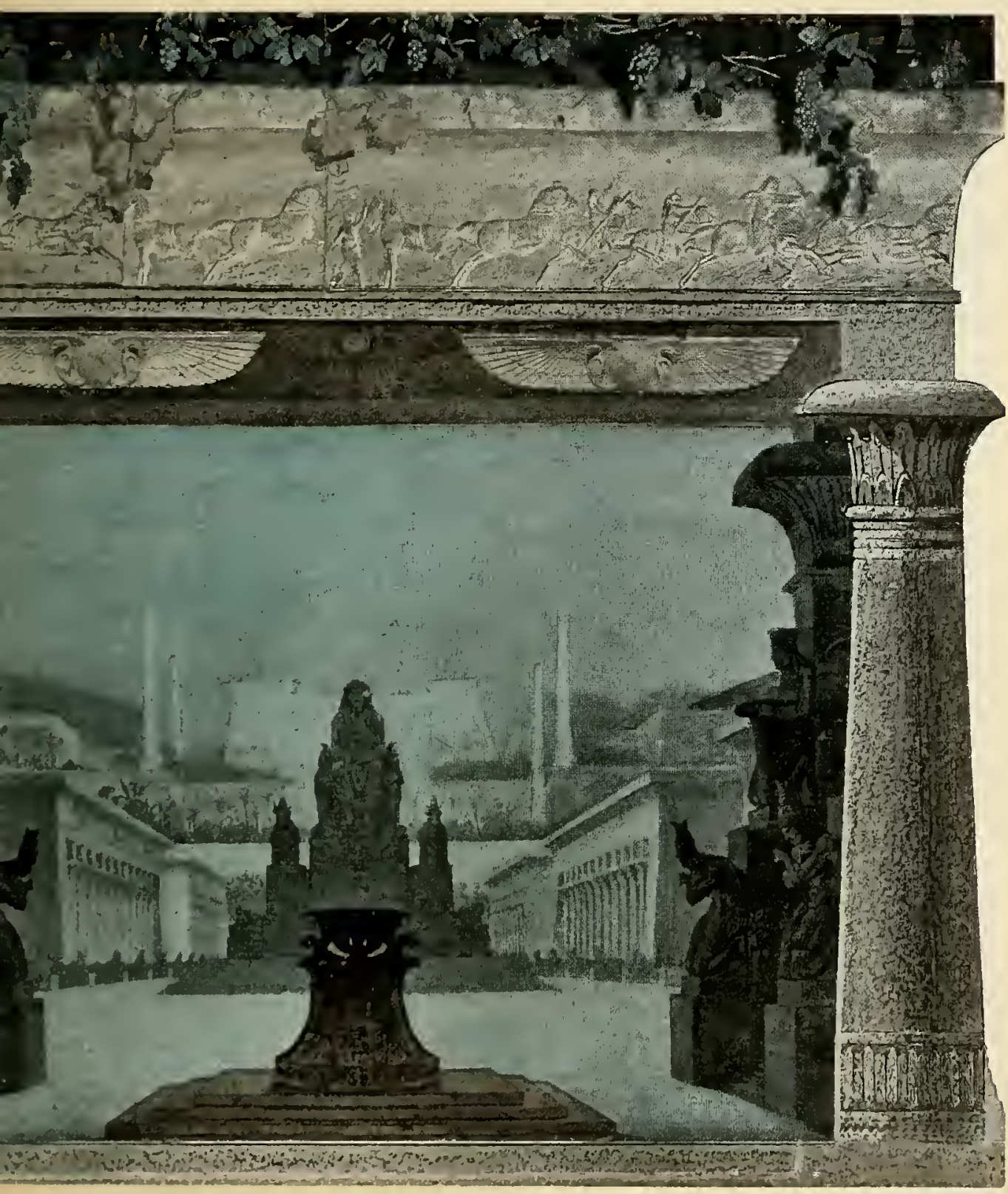





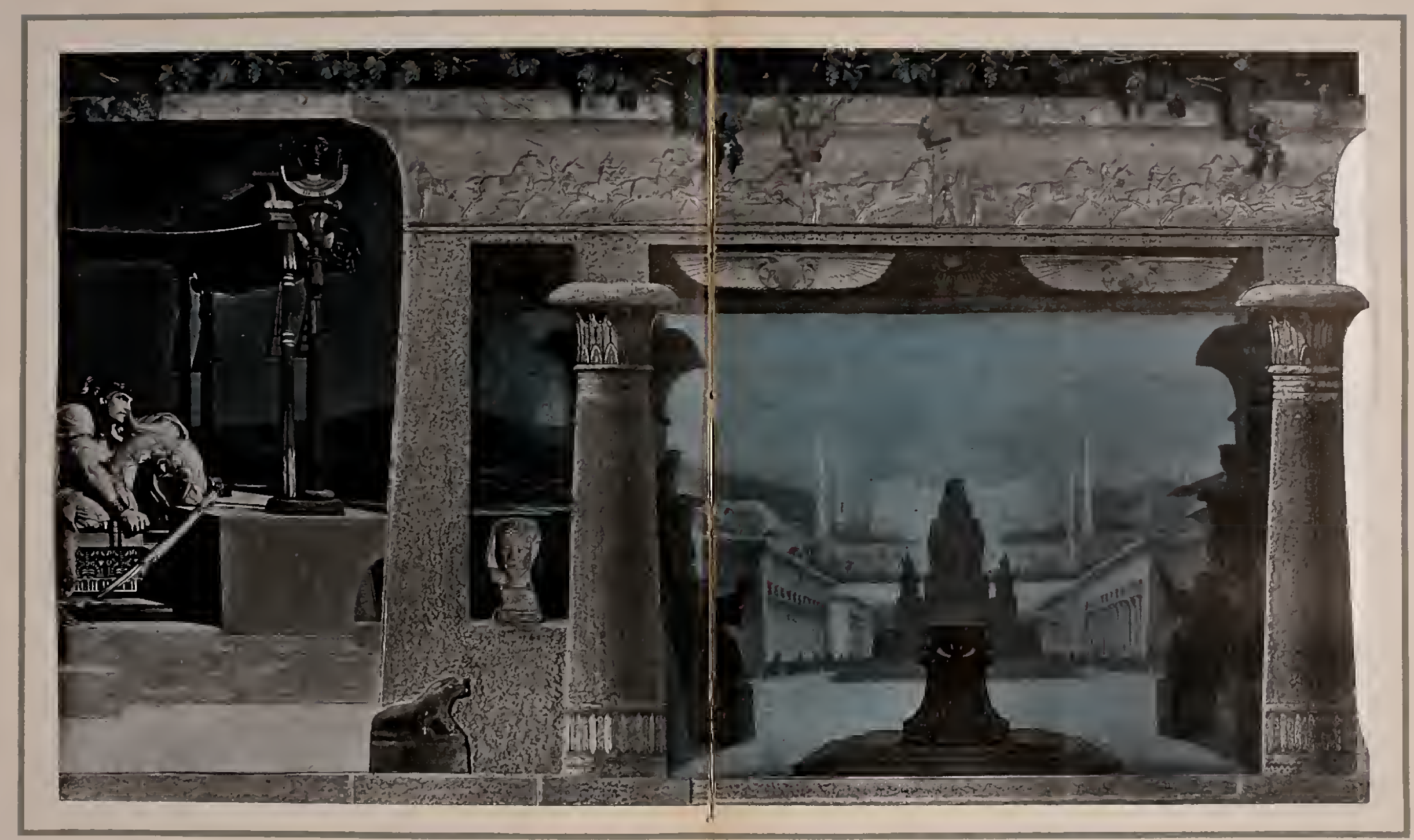

(a)

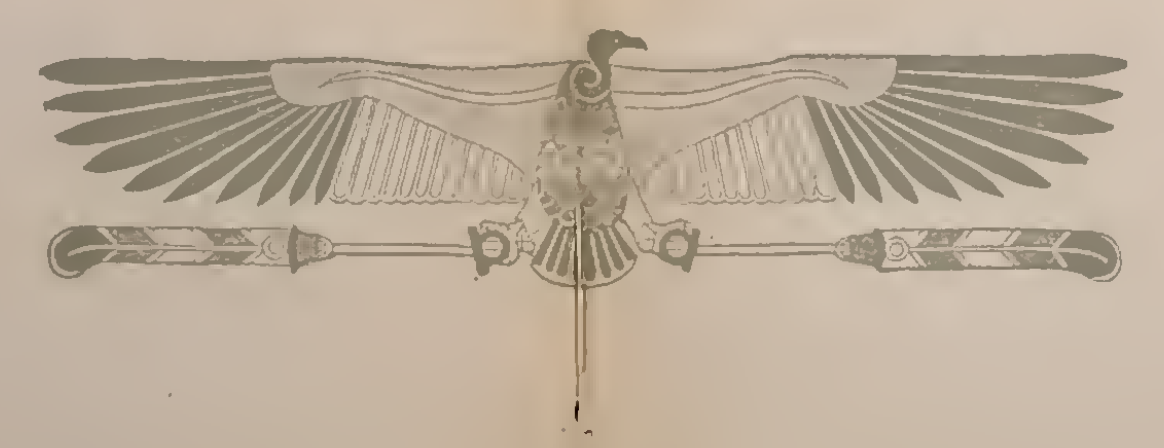

on Balcony 



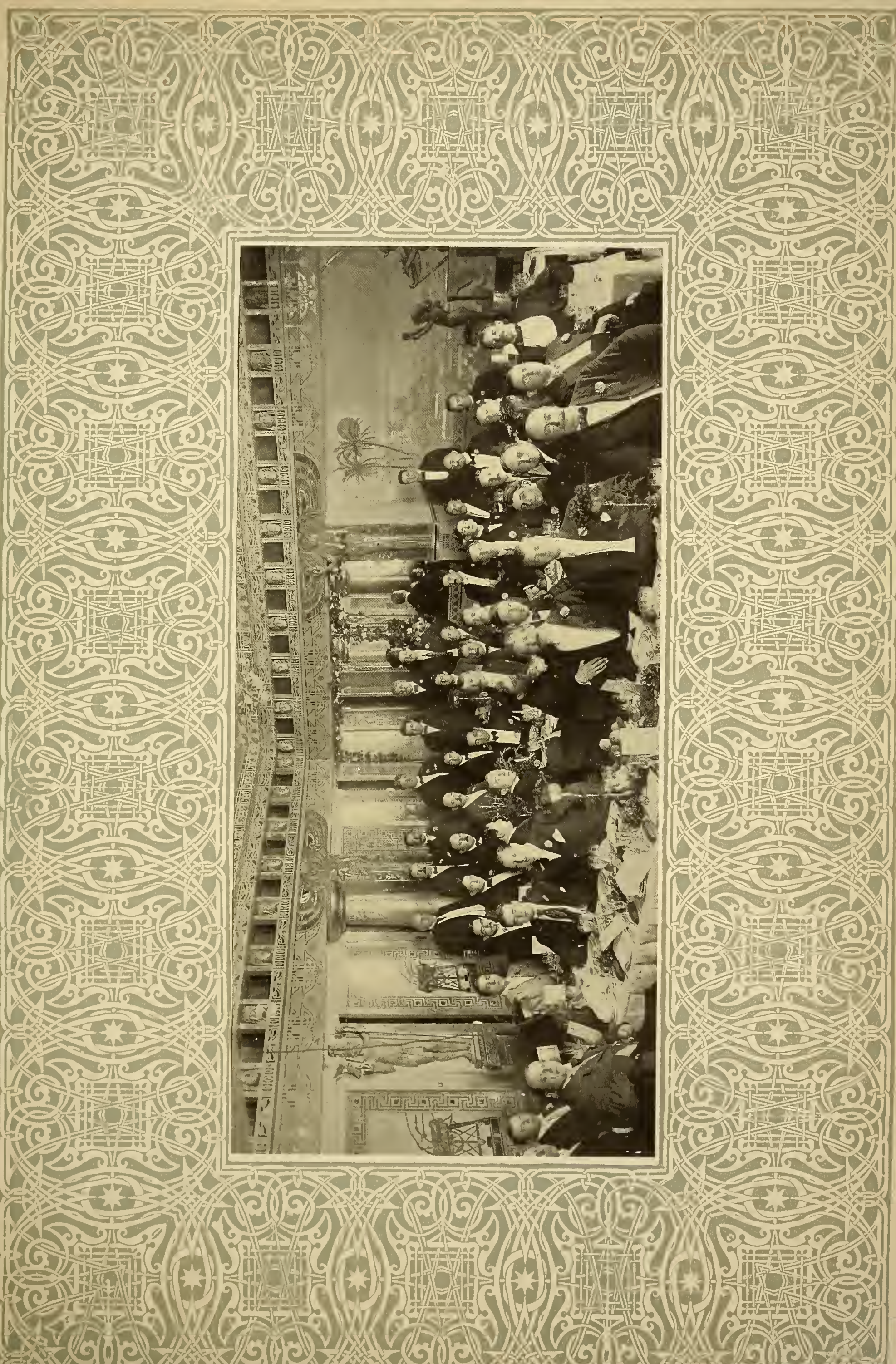




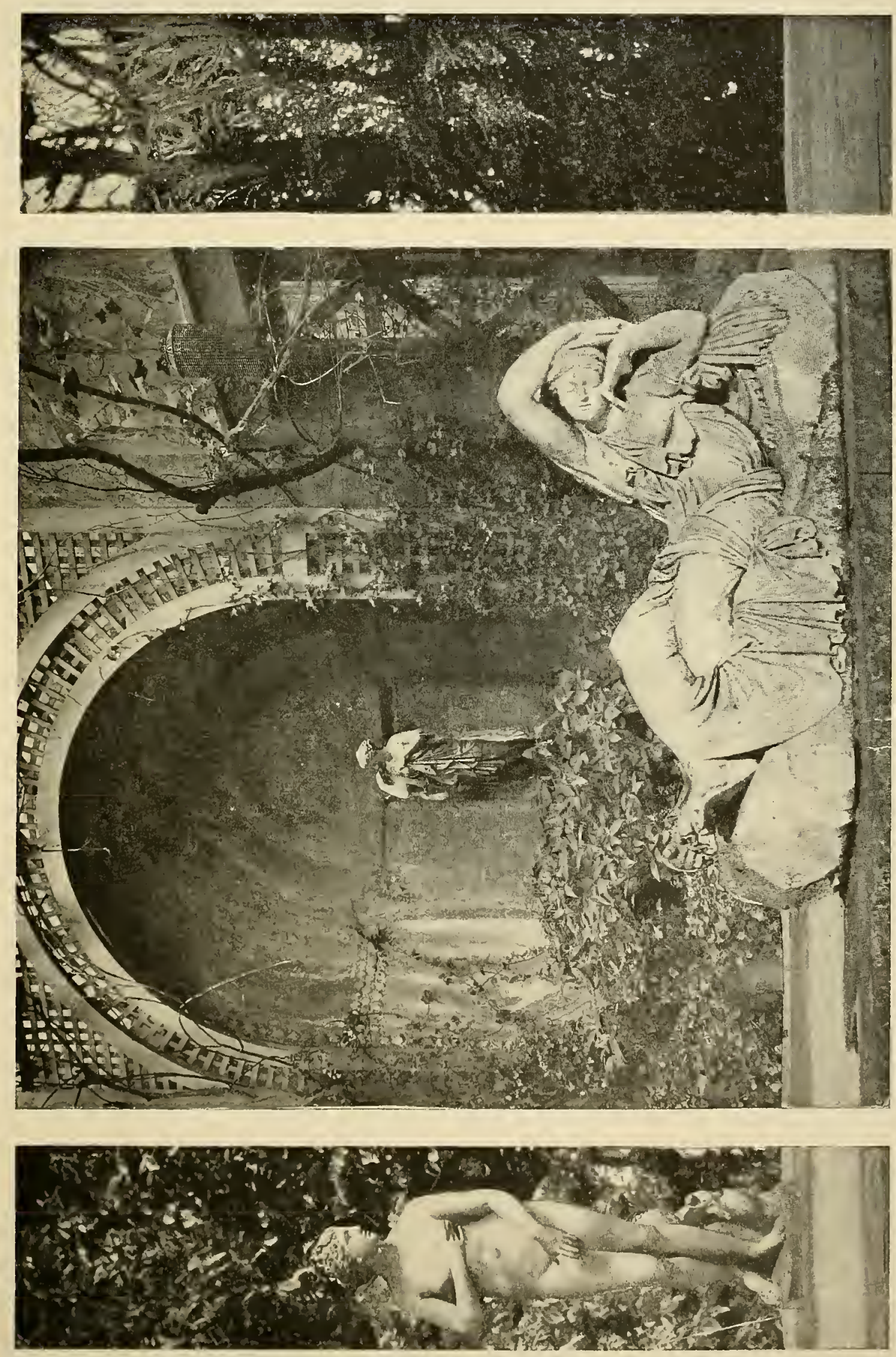



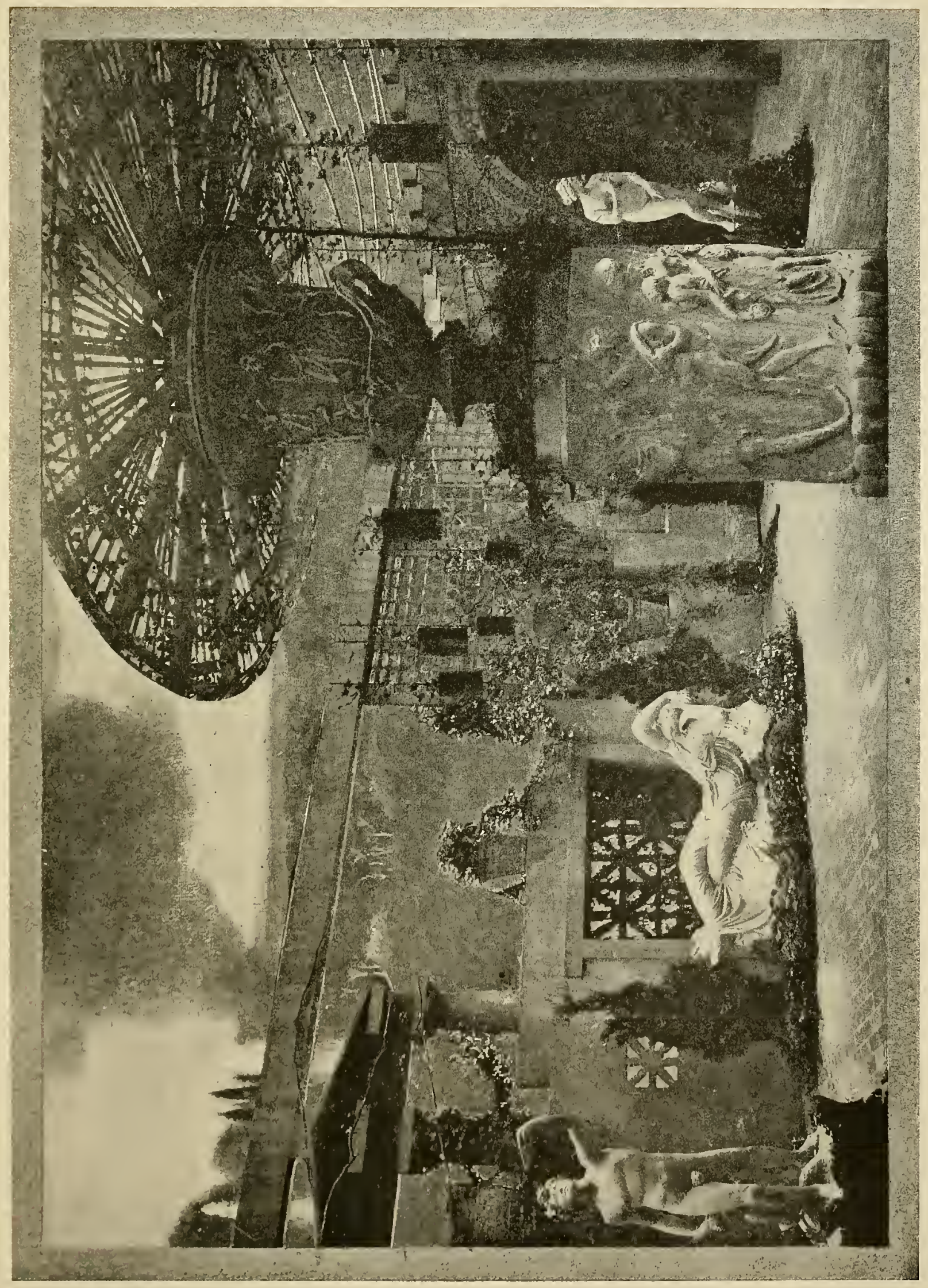





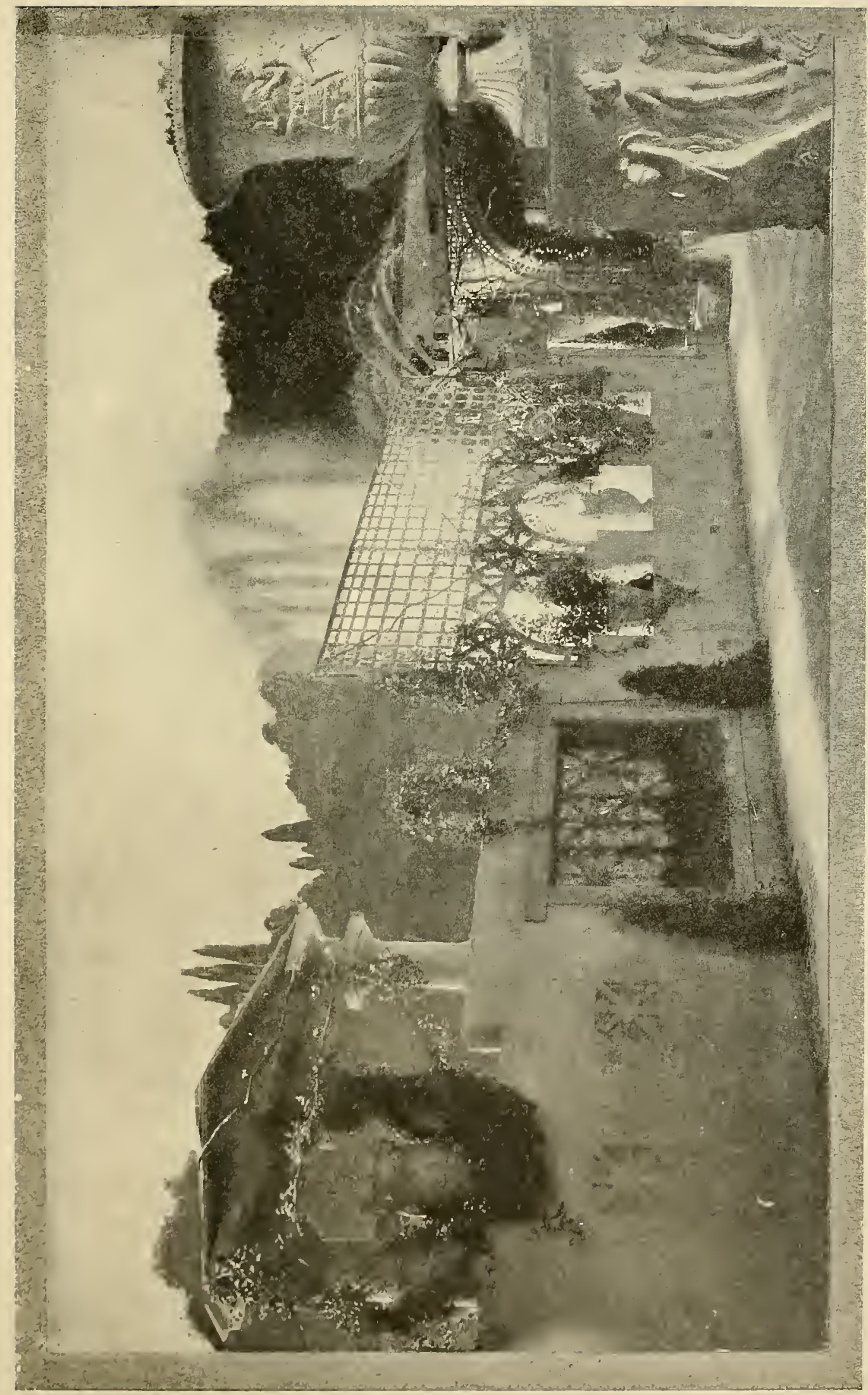




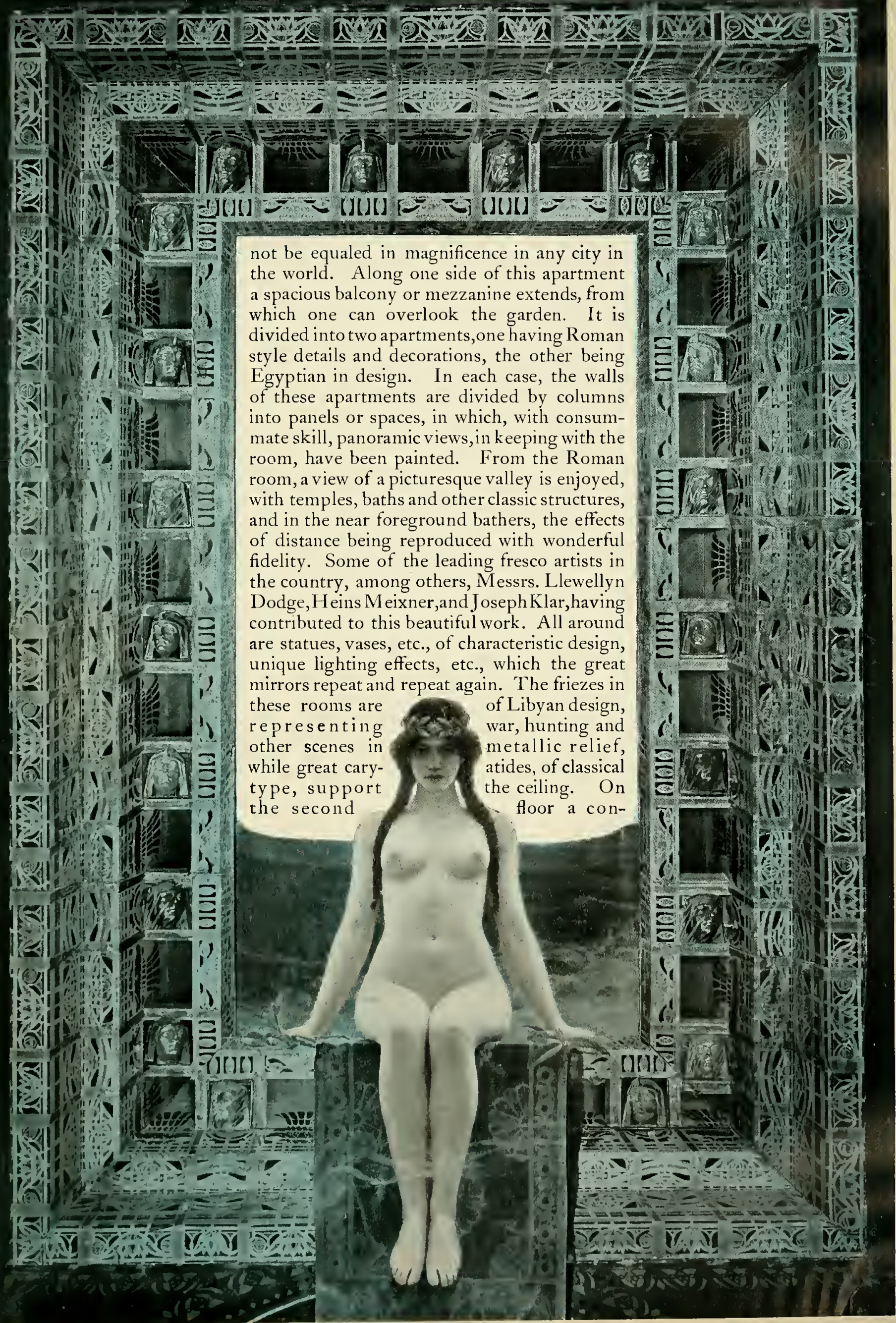




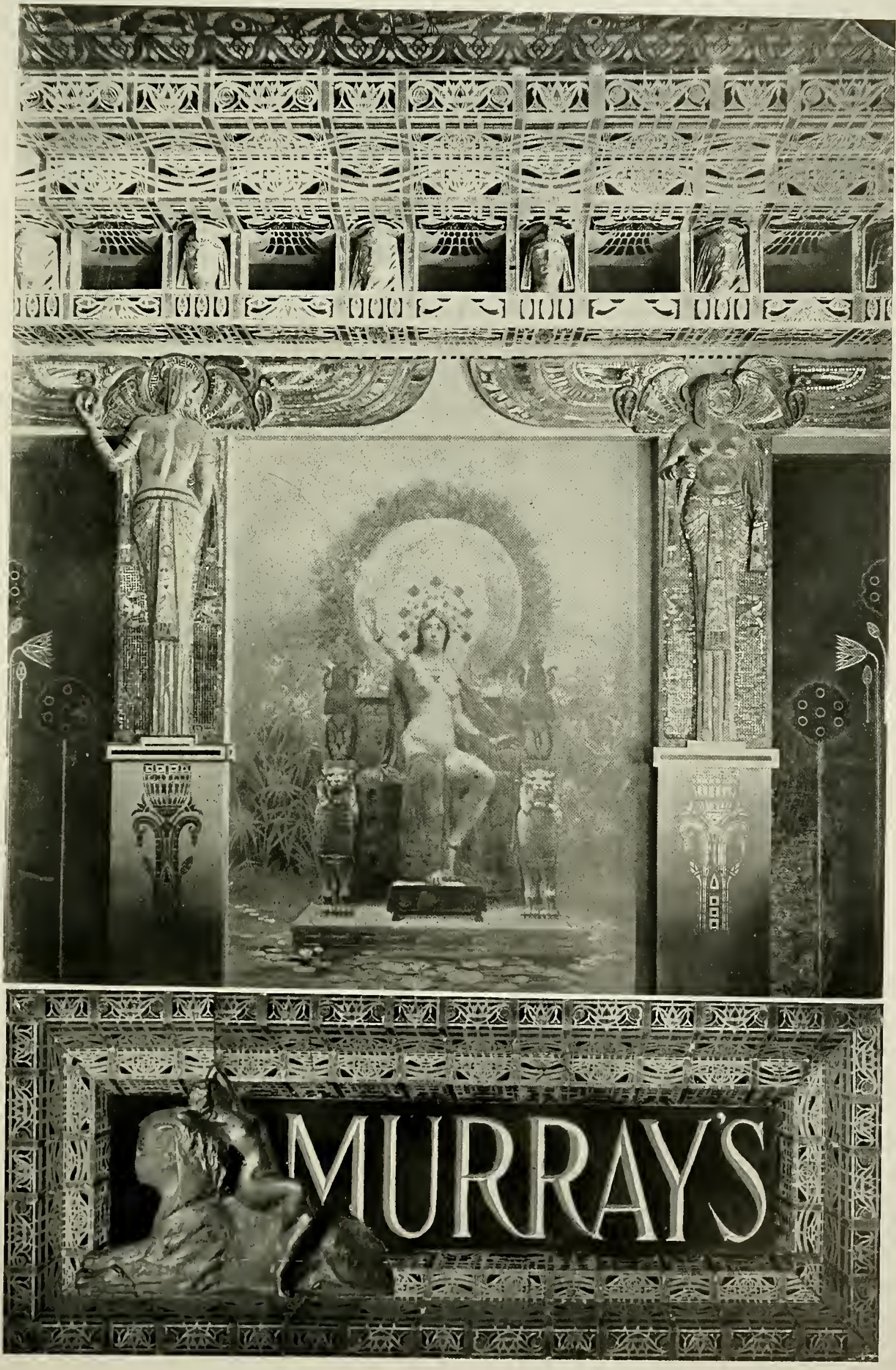



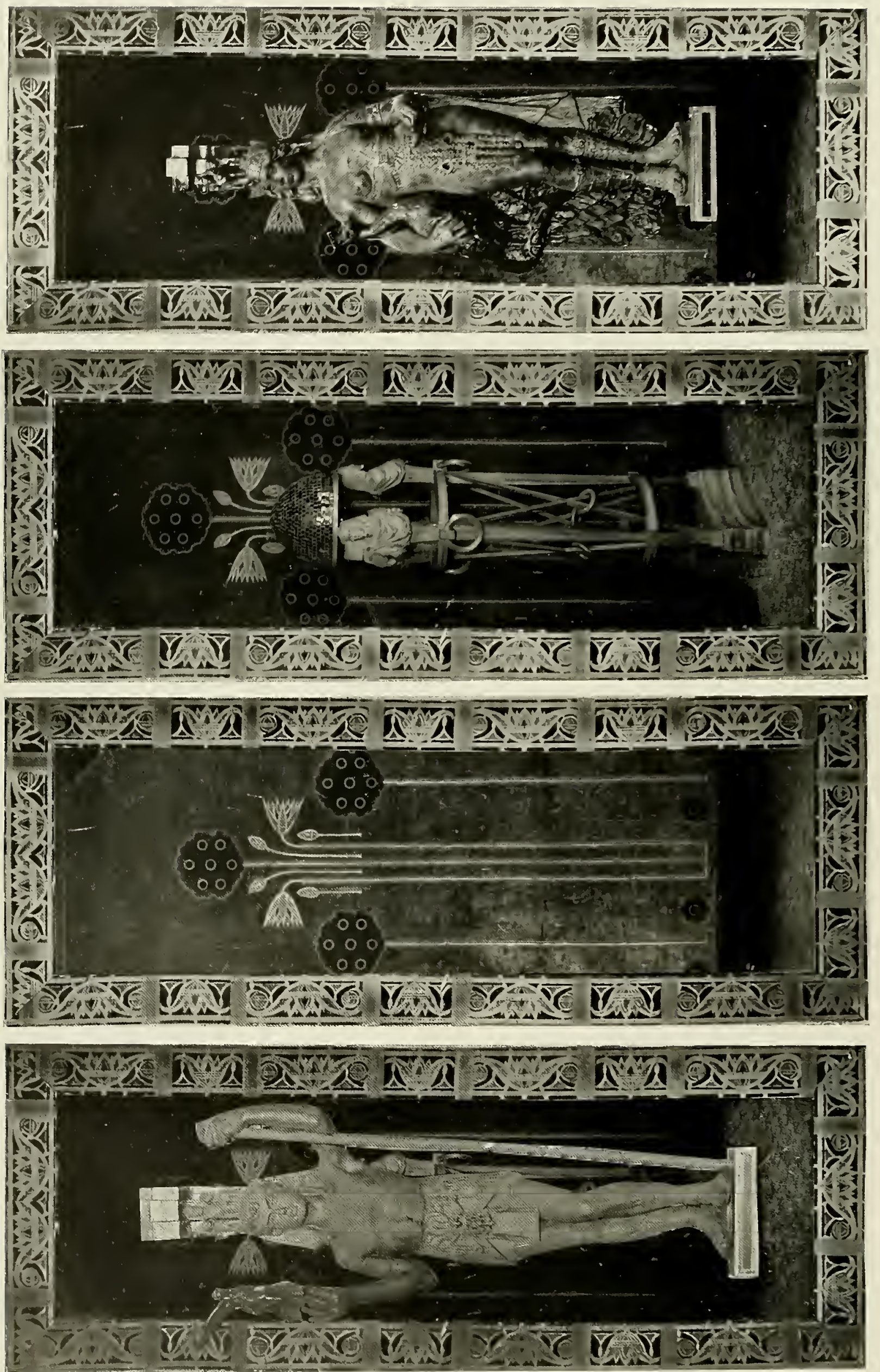


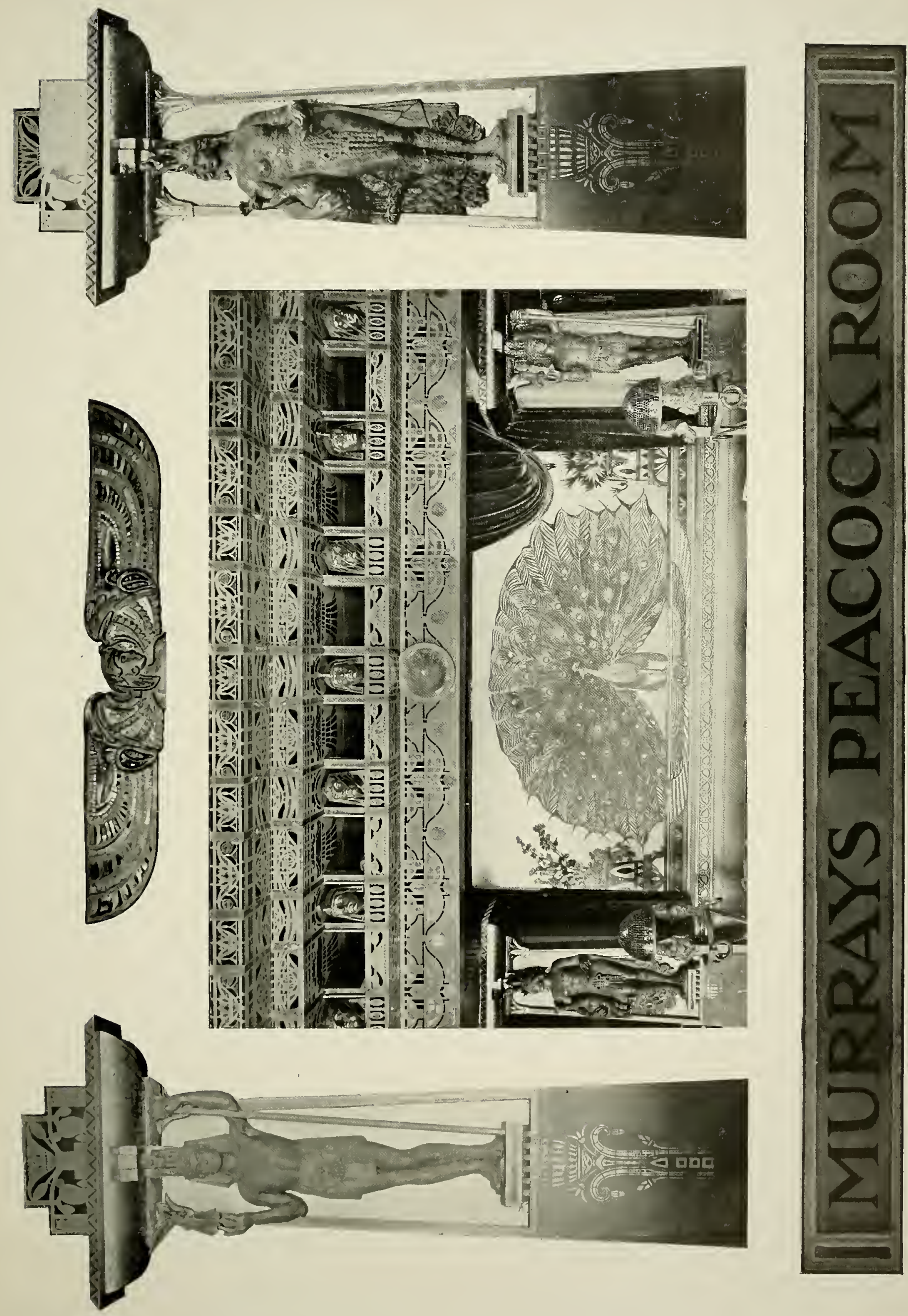




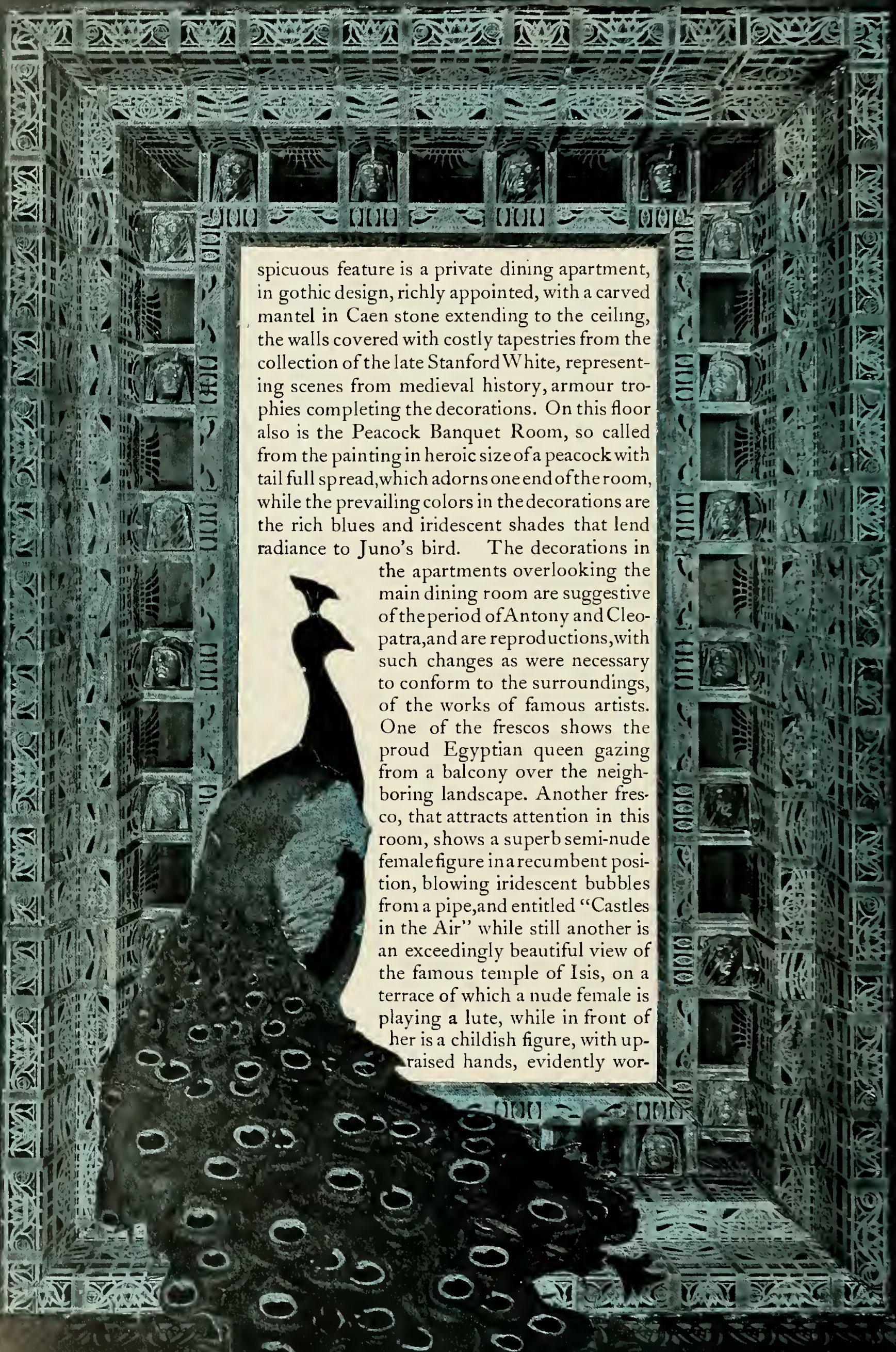




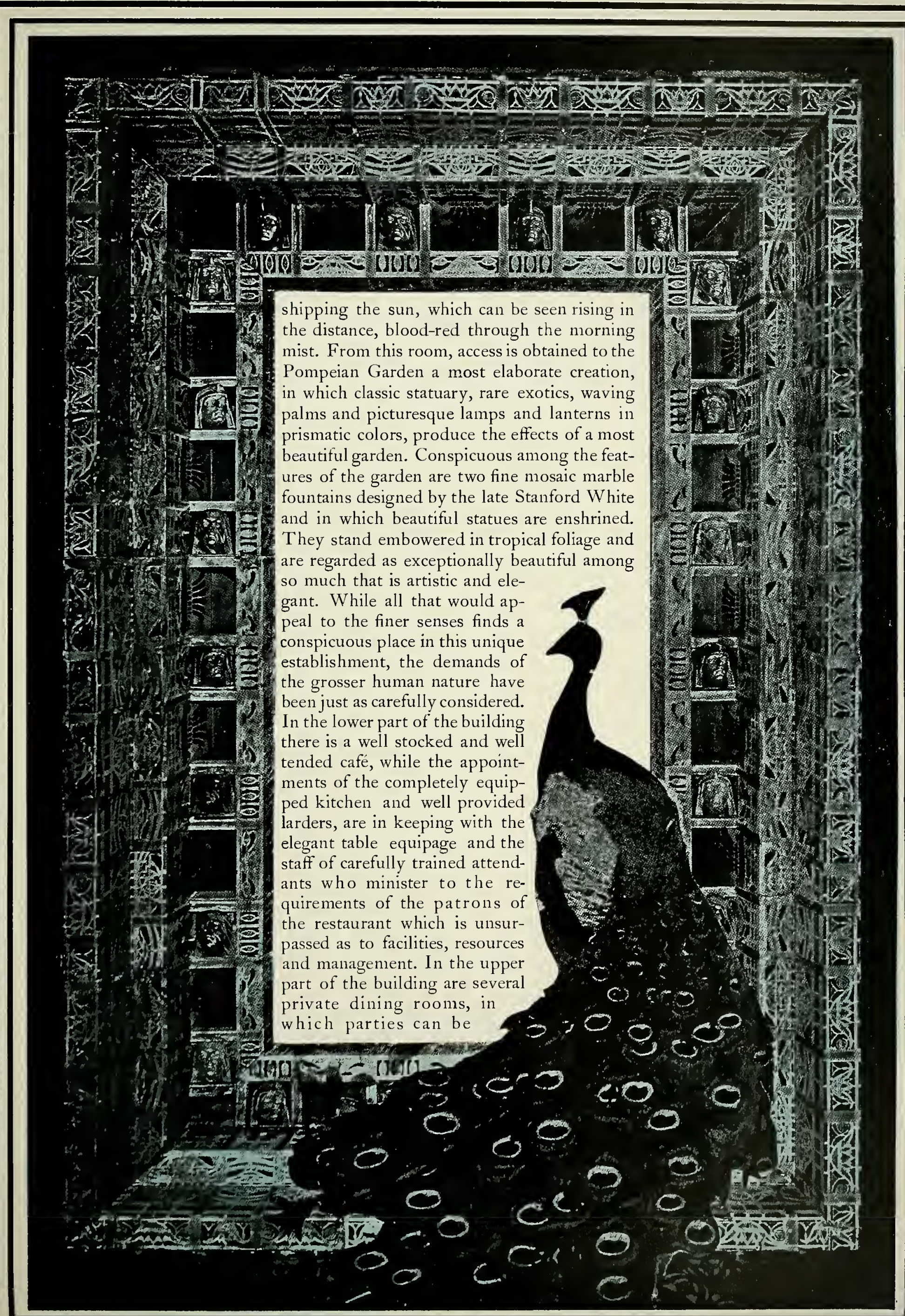




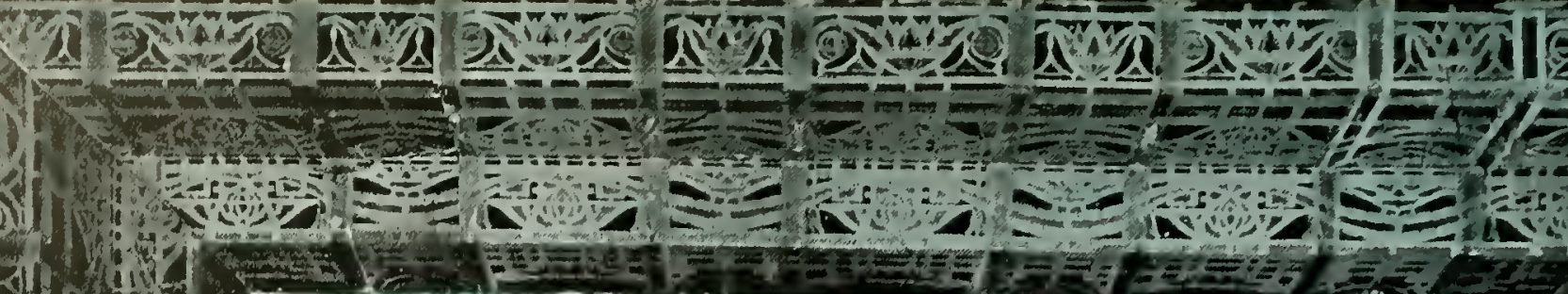

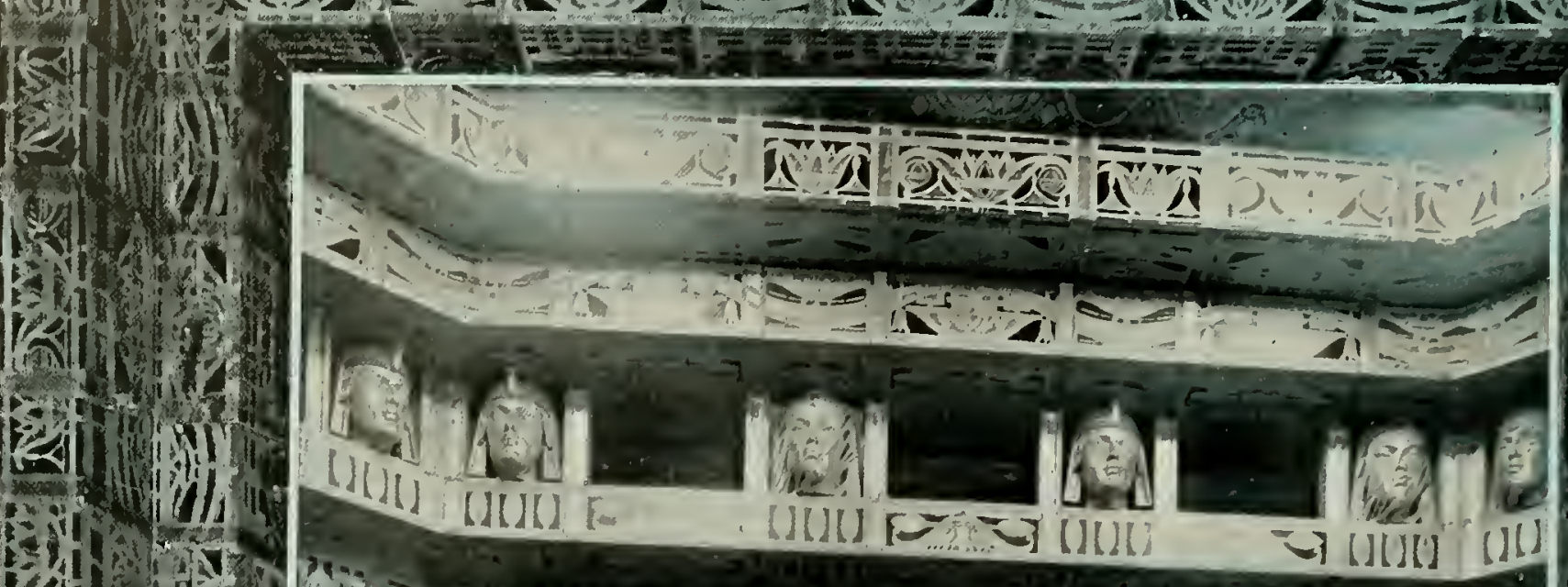

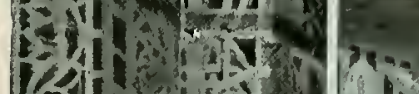

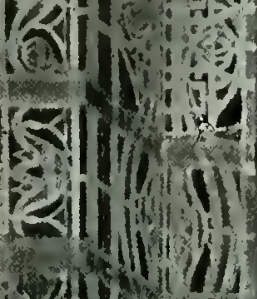

ivily

inton

mel

(a) 10.4

ralmin

Eslling

(9) $), 7,6$ in

a.

Kalnis

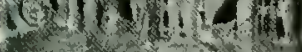

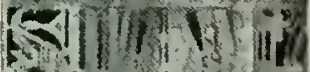

E-illinill

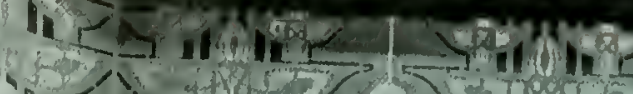
it.
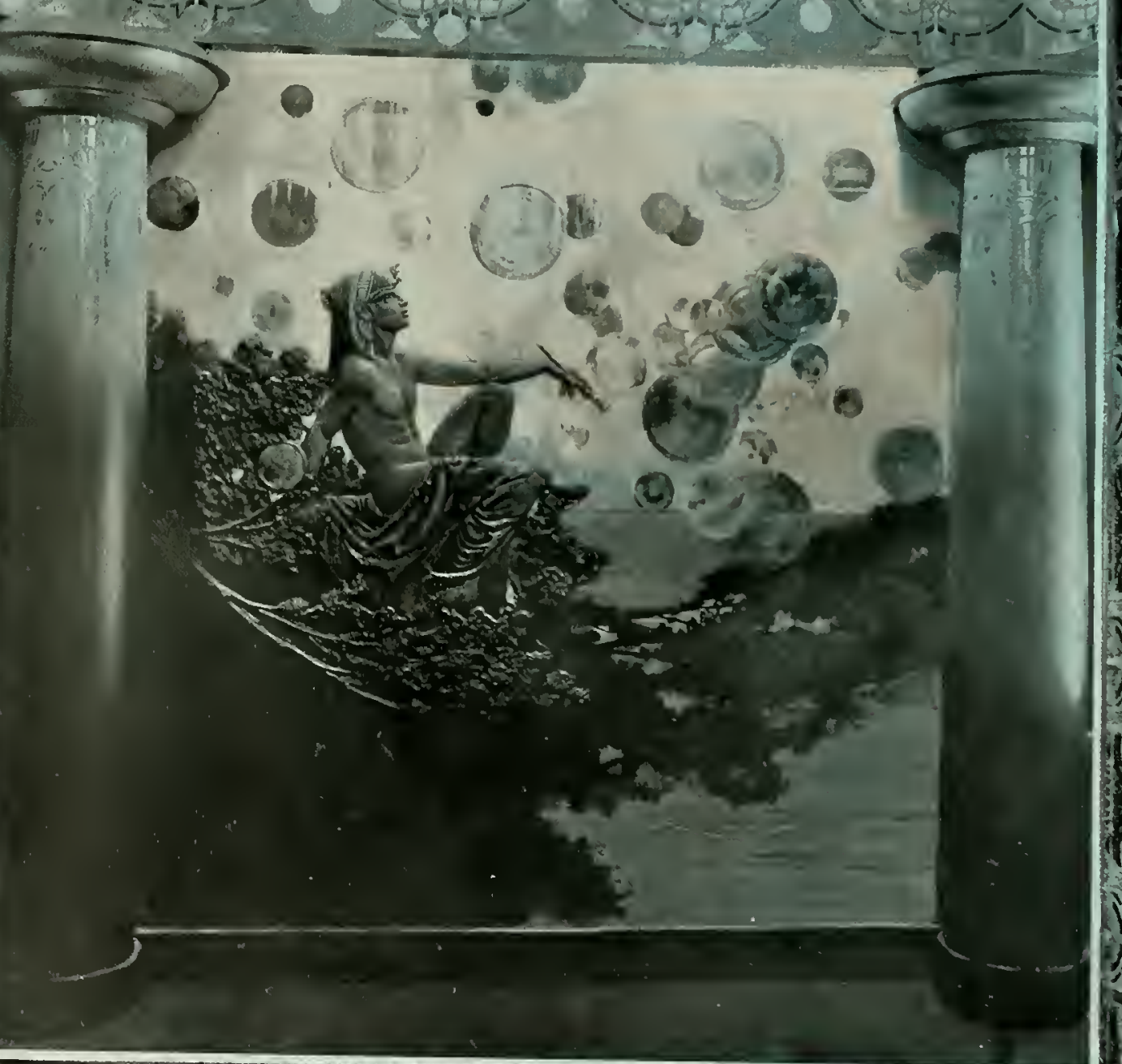

$1, \geq 1$

iv

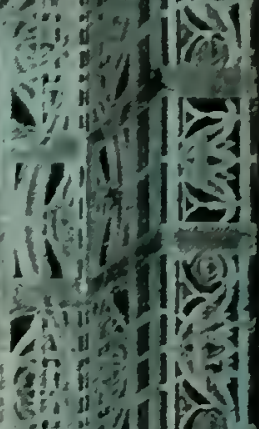
(6)| Eallowithing

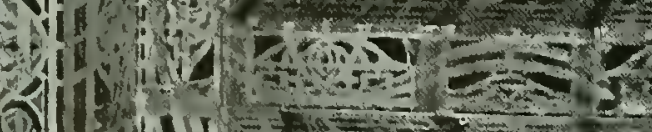

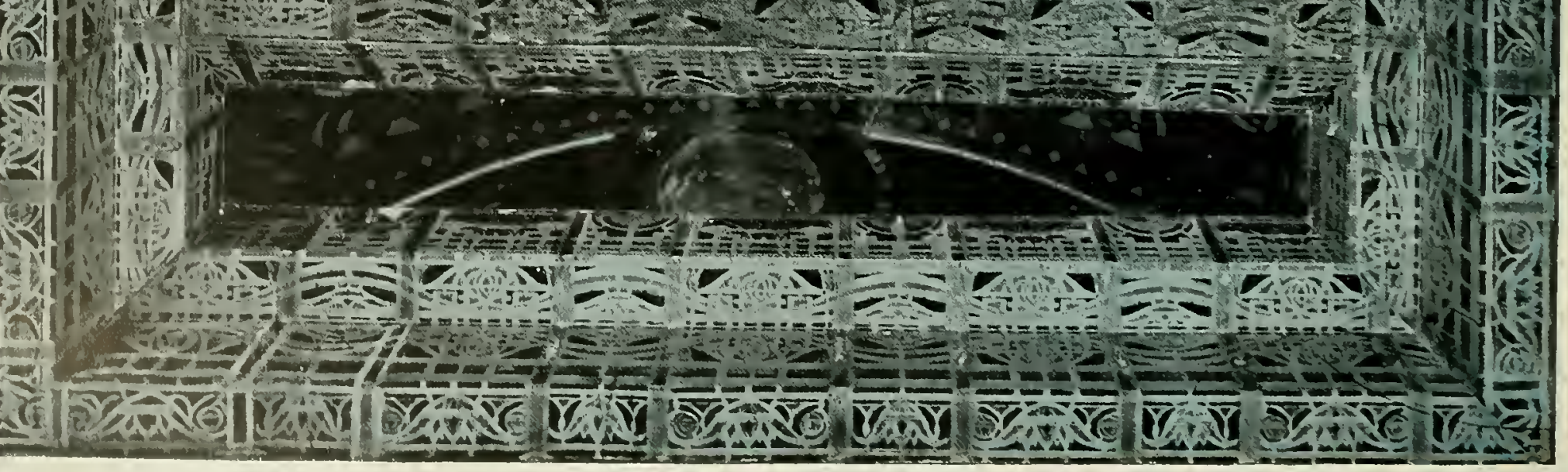


스른

……

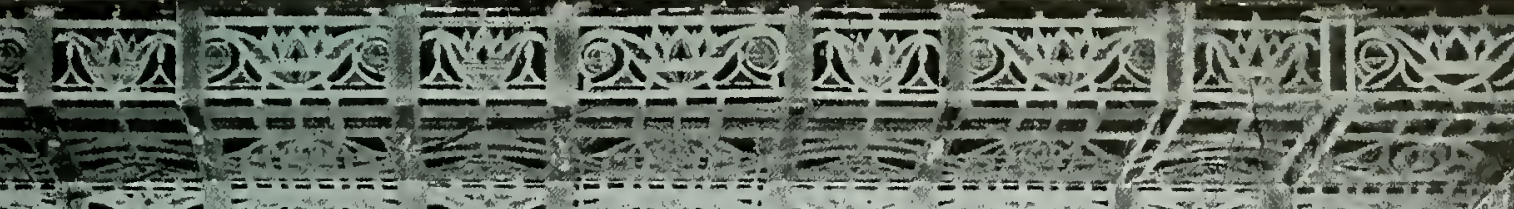

(0) 1 (1)

foilm

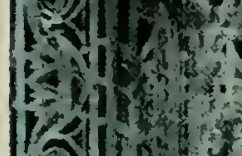

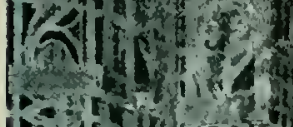

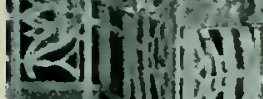

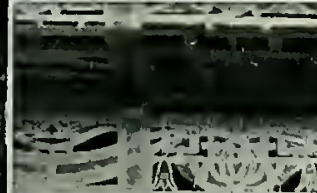

$\therefore=$

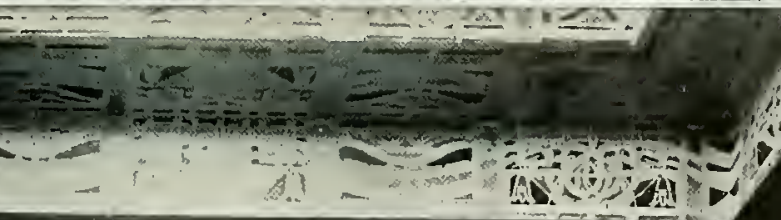

a. HD Ho

Evil

IIIIJ -51

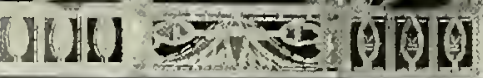

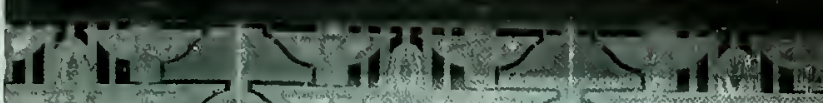

15

10

(6)

Ir)

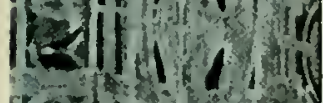

(x) lying ofing

(3)

oll un 2 m

(E)III M in

绿同 11140

I

Ćll in

है। If 1 in

silfili an

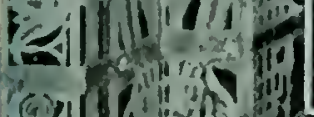

livis b

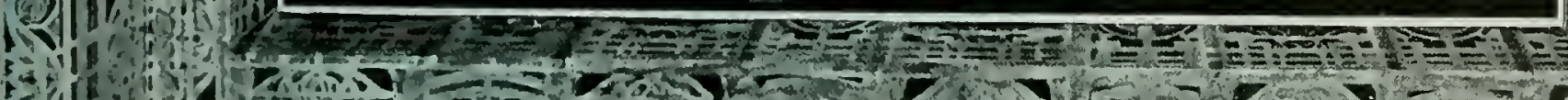

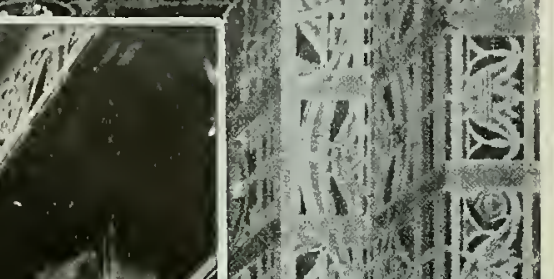

is

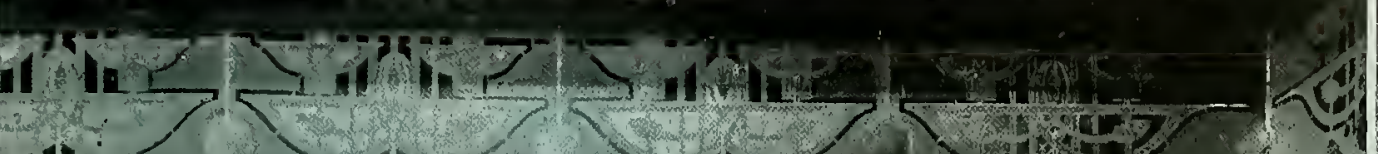

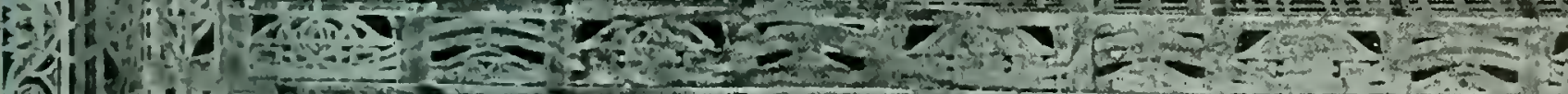

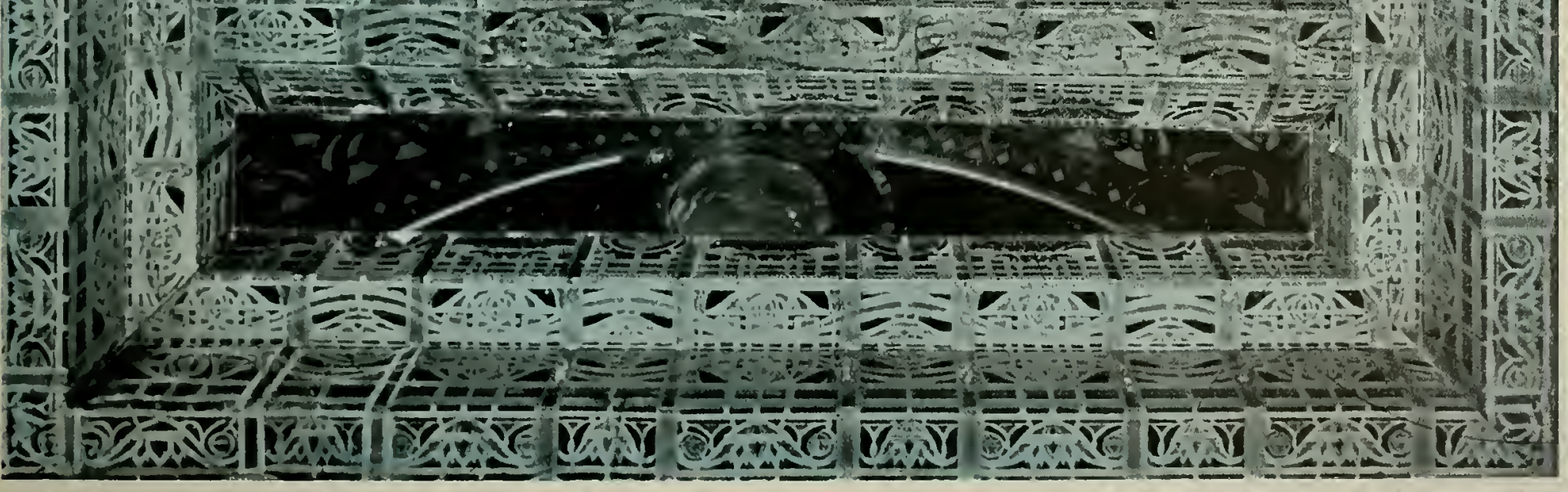




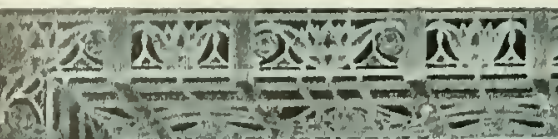

NIti $=-2,2=-2$

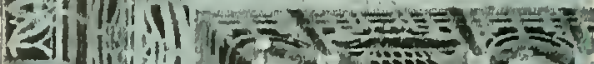
(Fily,

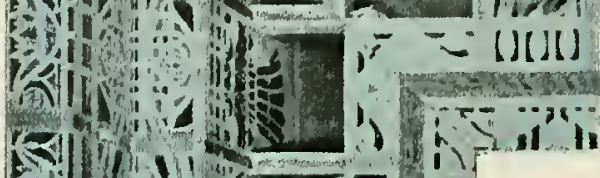

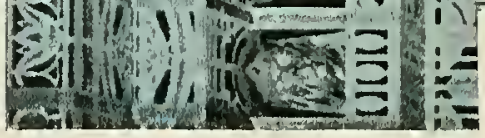

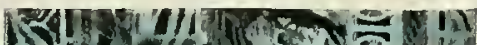
Bil $1-20$

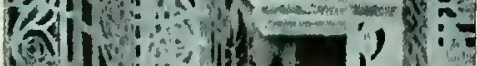

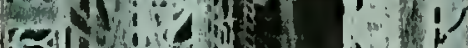
हลำ

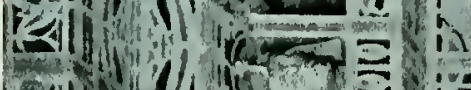

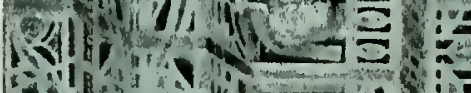
Fit

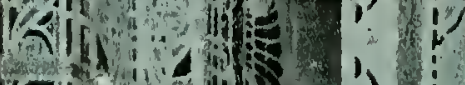
anflum ')

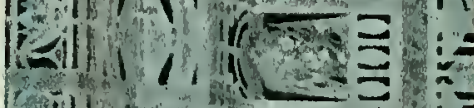
rille $\rightarrow$ at E.ti

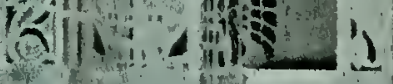

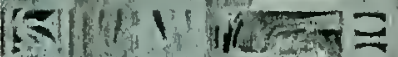
siln $11 \mathrm{ML}=$

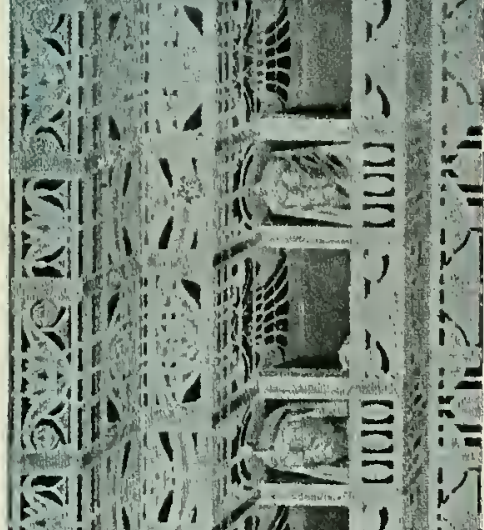
Fin livil $11=$ $1,1,4 \sqrt{\mathrm{Na}} \equiv$

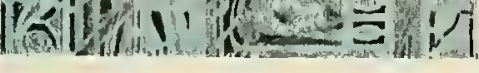

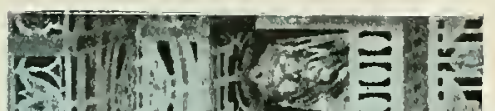

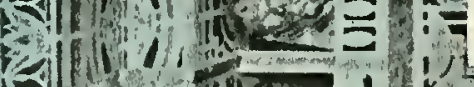

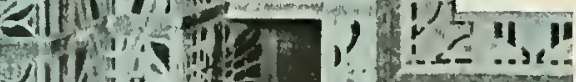

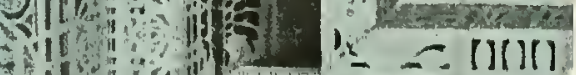

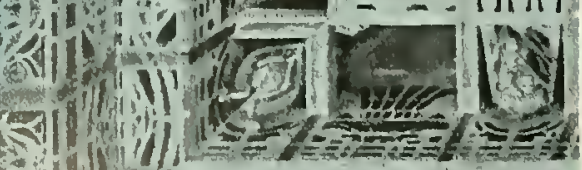

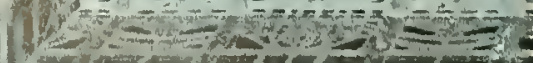
$\overline{\mathrm{V}} \overline{\mathrm{y}} \overline{\overline{\mathrm{V}}} \overline{\bar{y}}$ r

$\therefore=-2=$

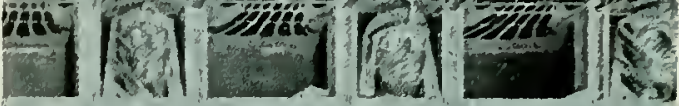

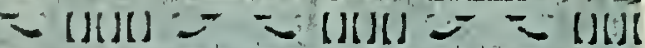

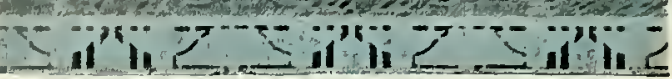

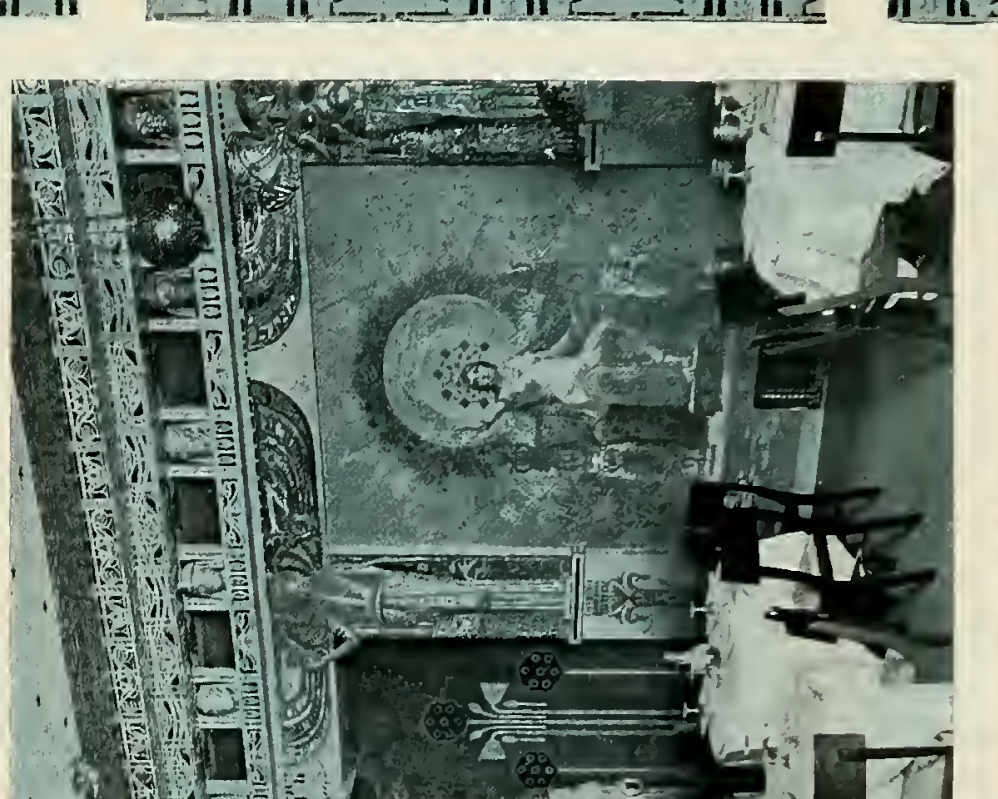

$-:=E$ ind

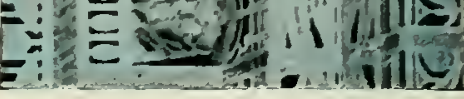

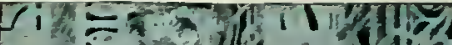

-:

$=1,-1, \quad n$

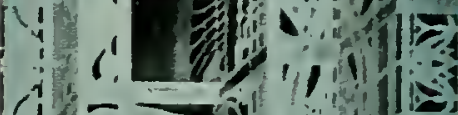

$=0$ -

$=1,5=0$

(y) = 3ill

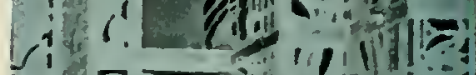

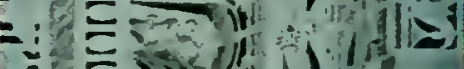

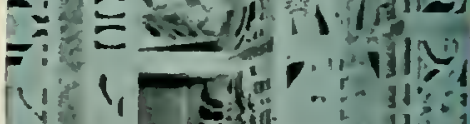
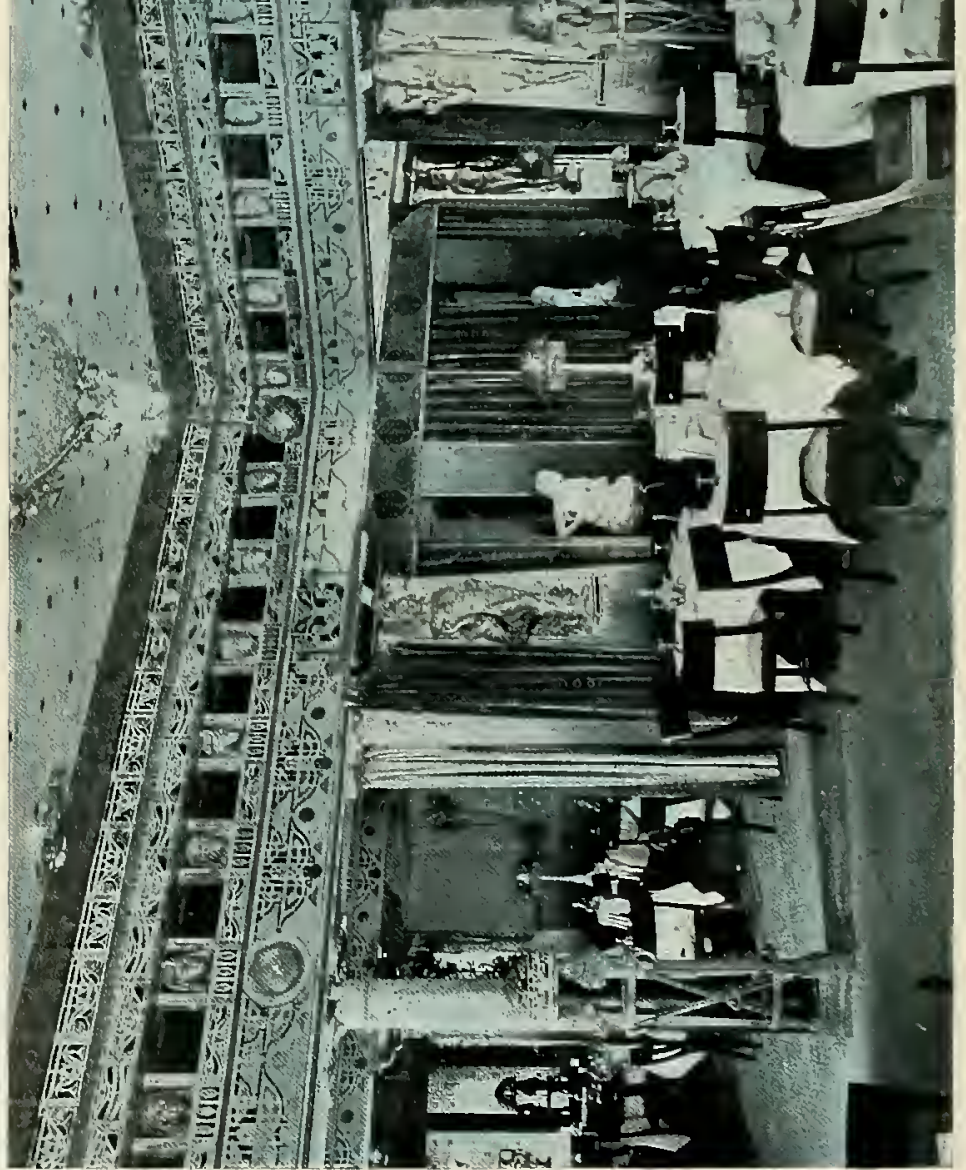

$\Rightarrow \sin ^{1} / 1+10$ ELETH 1 ifll: T. SU N (1) Prf

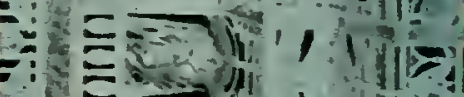

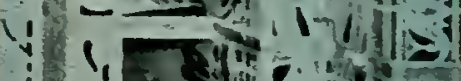
(1) 1 मी $=: 51-42$

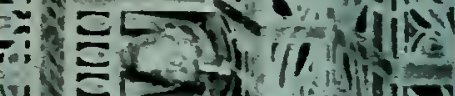
$\because x=0-1$ i i! Jut

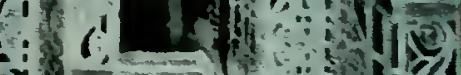

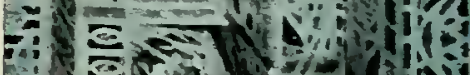
(iv)

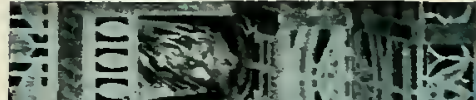

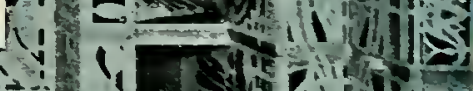

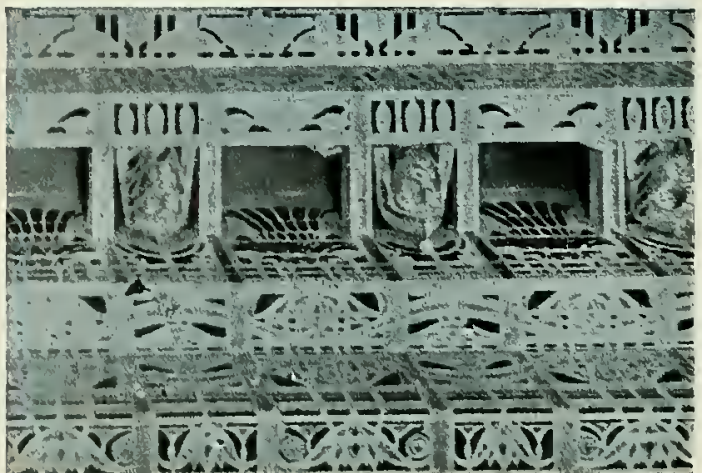

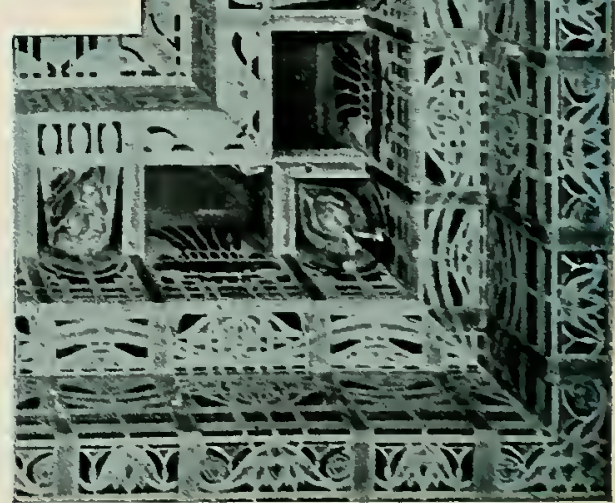




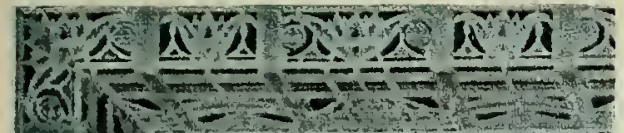
|SI) $=-2,0=$ (rive (A) I,

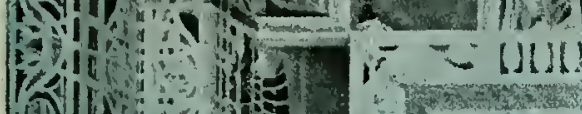

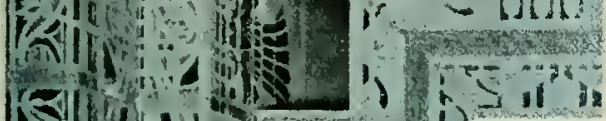
SAl Find if 140

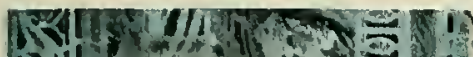
(1) $1=3$ (Ning and nith

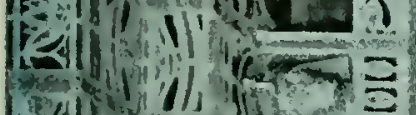
is $11,40-3$ ming Iting finl if

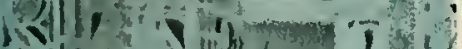

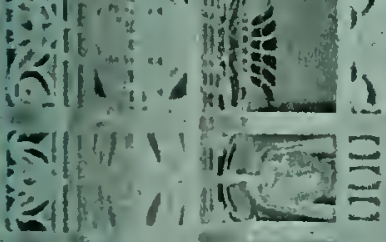<smiles>C#CC#CC#CC#[Si]</smiles>
<il (N) 1 180 Bill (1), 10

161,$\quad 150$ - $11-3$ 1 r ,

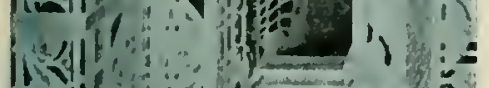
linidin Wnil

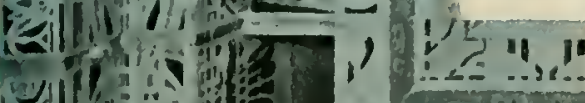

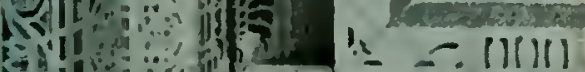

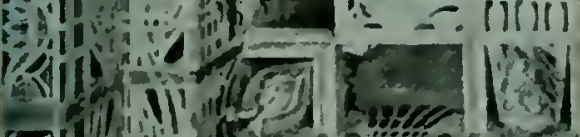

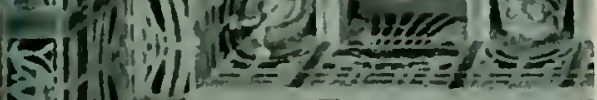

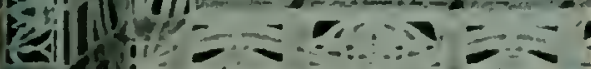

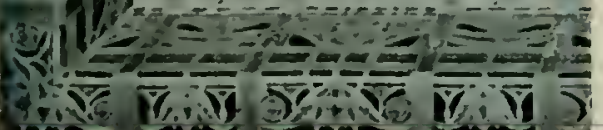

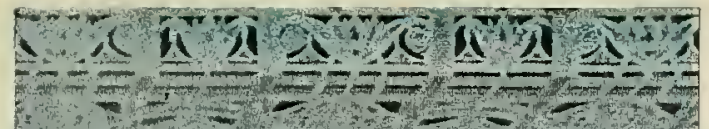

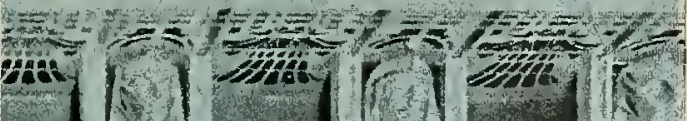

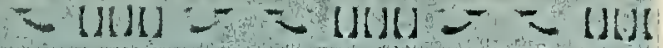

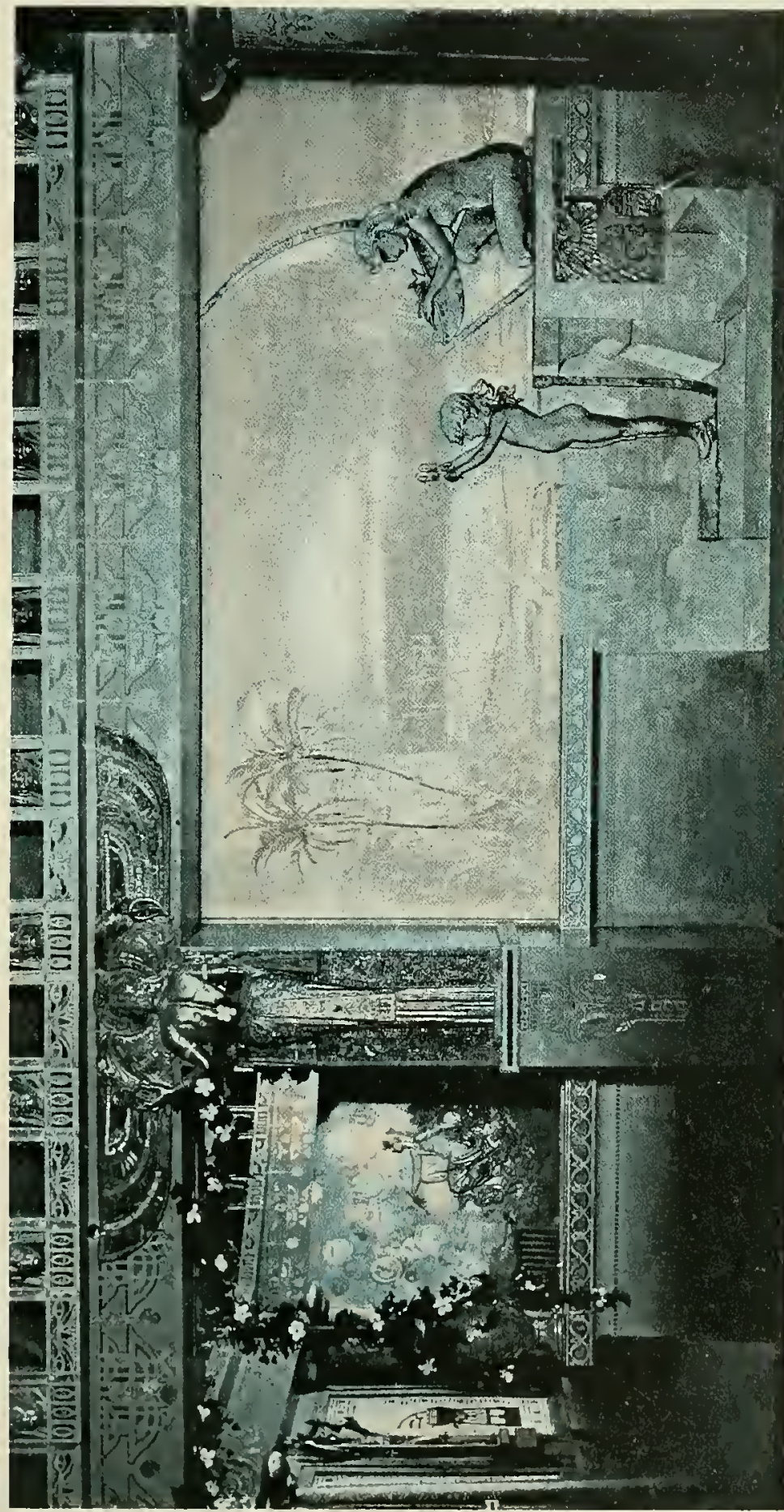
$\because-2-1, z=2$ |nal Jut L

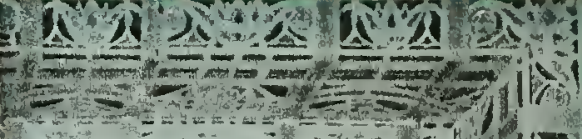

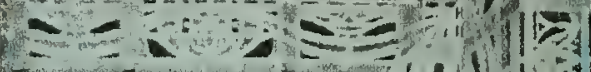

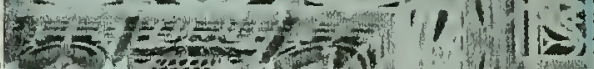

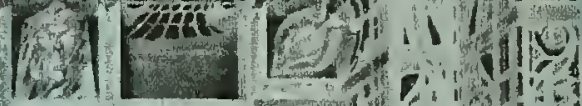
แUน $=-1 / 2$ t

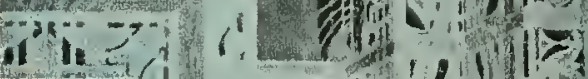

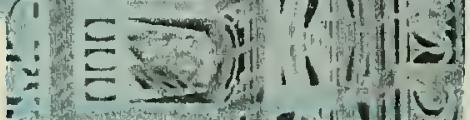

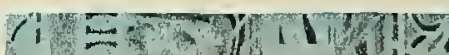

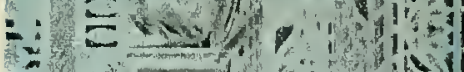

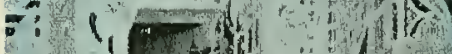

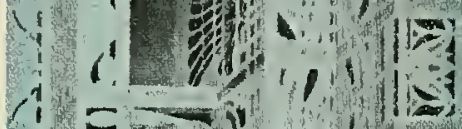

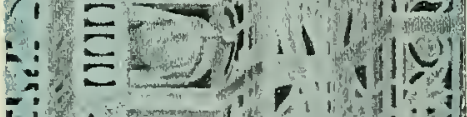
$\because 1,5$ b c. c

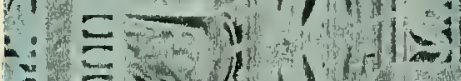
$1,-6,110$

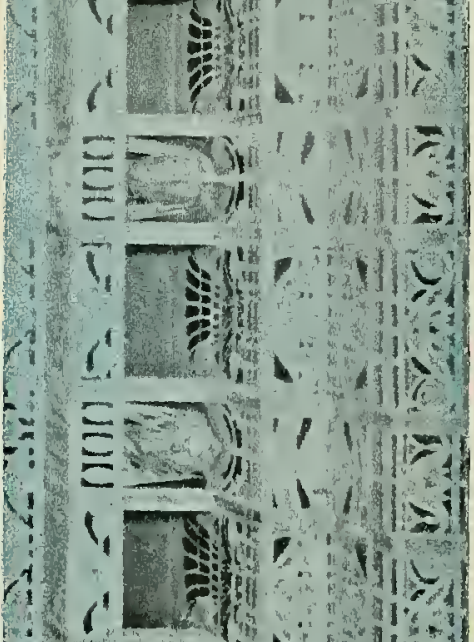
$y=-5$ d (4) E 1. $14.114=$

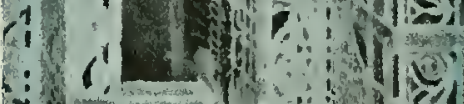
$\therefore \quad 50 \quad 0$

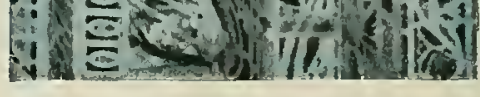

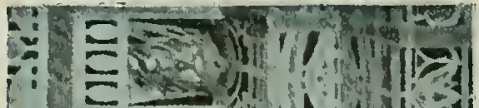

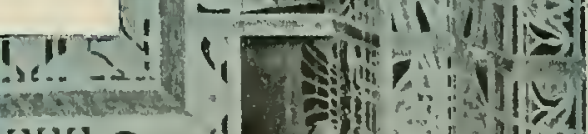
IIIII $=-2$ 121 and

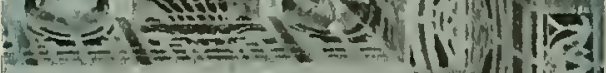
$z=-20=-4$ y

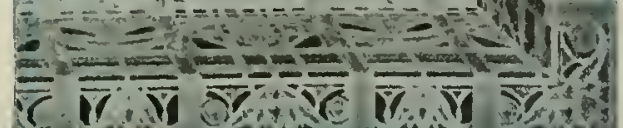



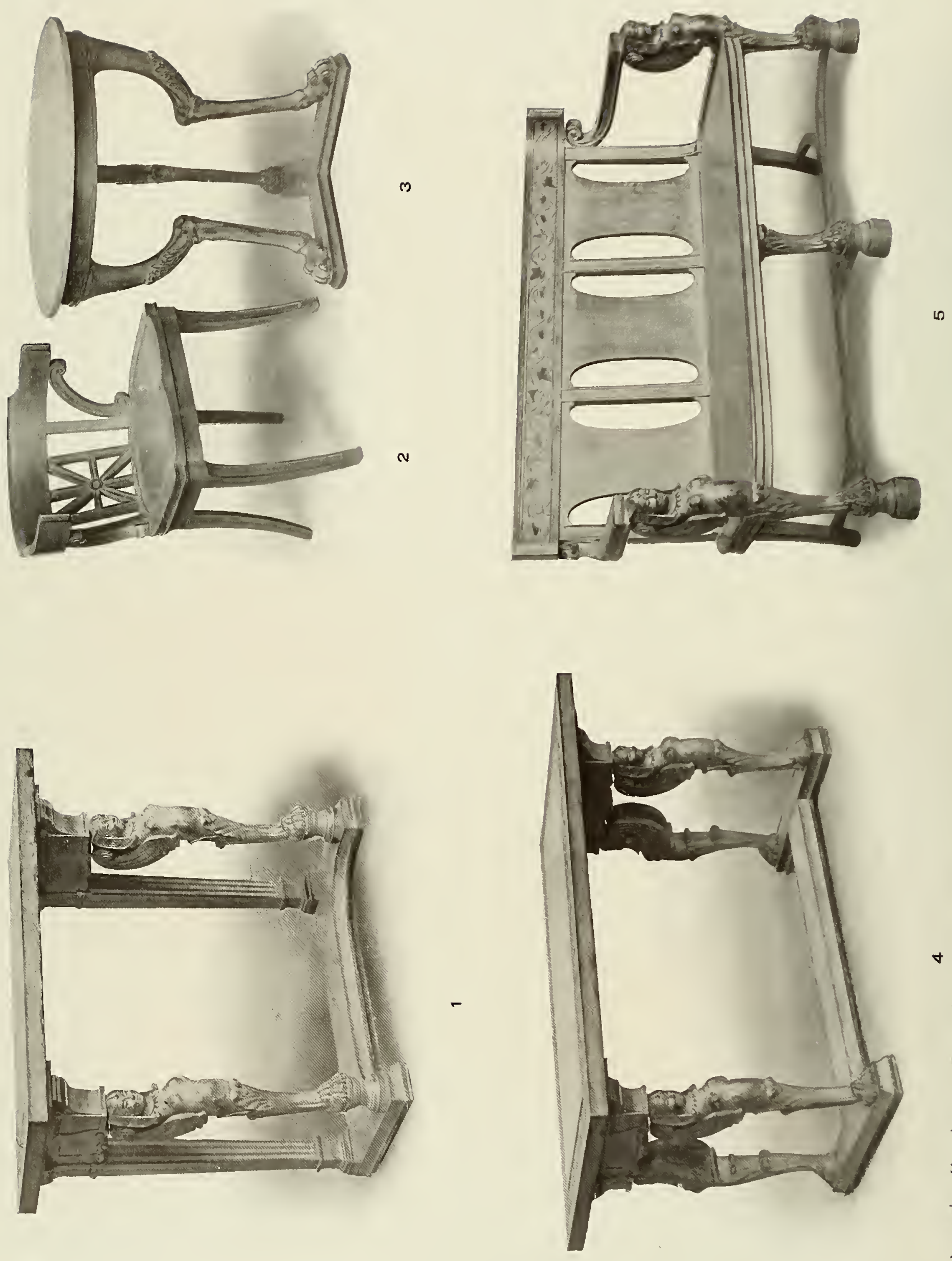

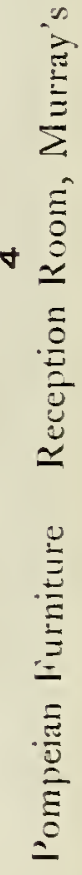



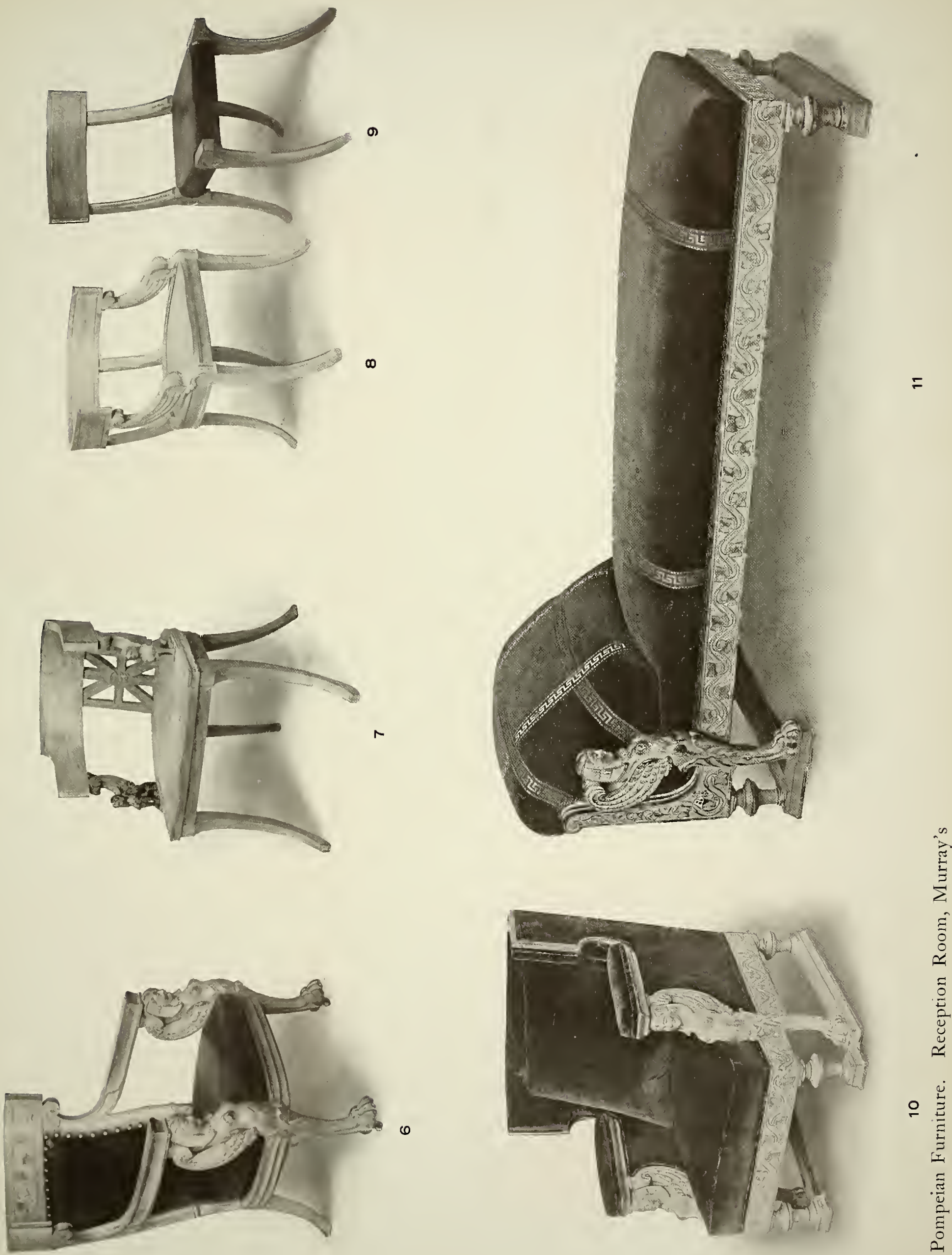


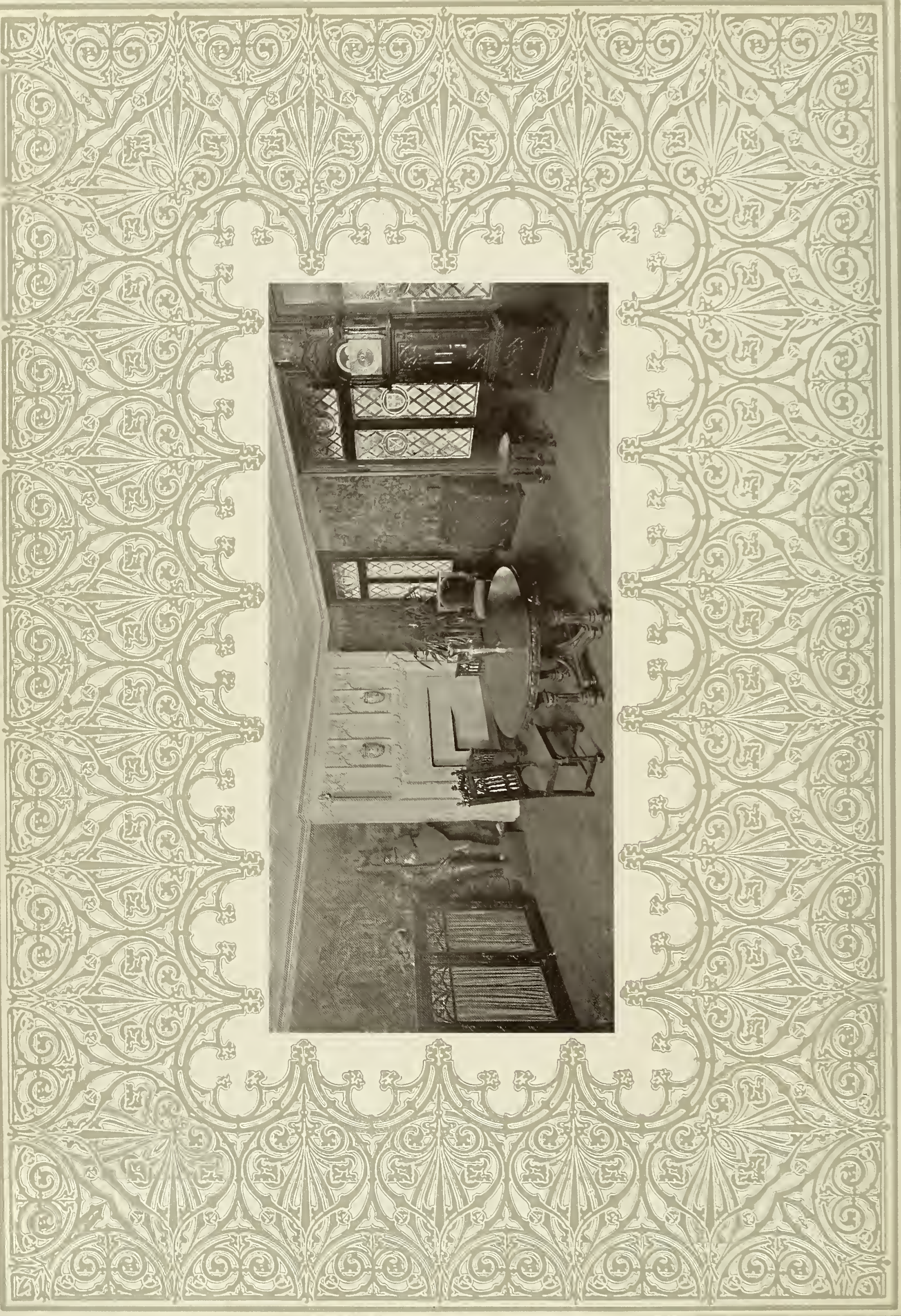



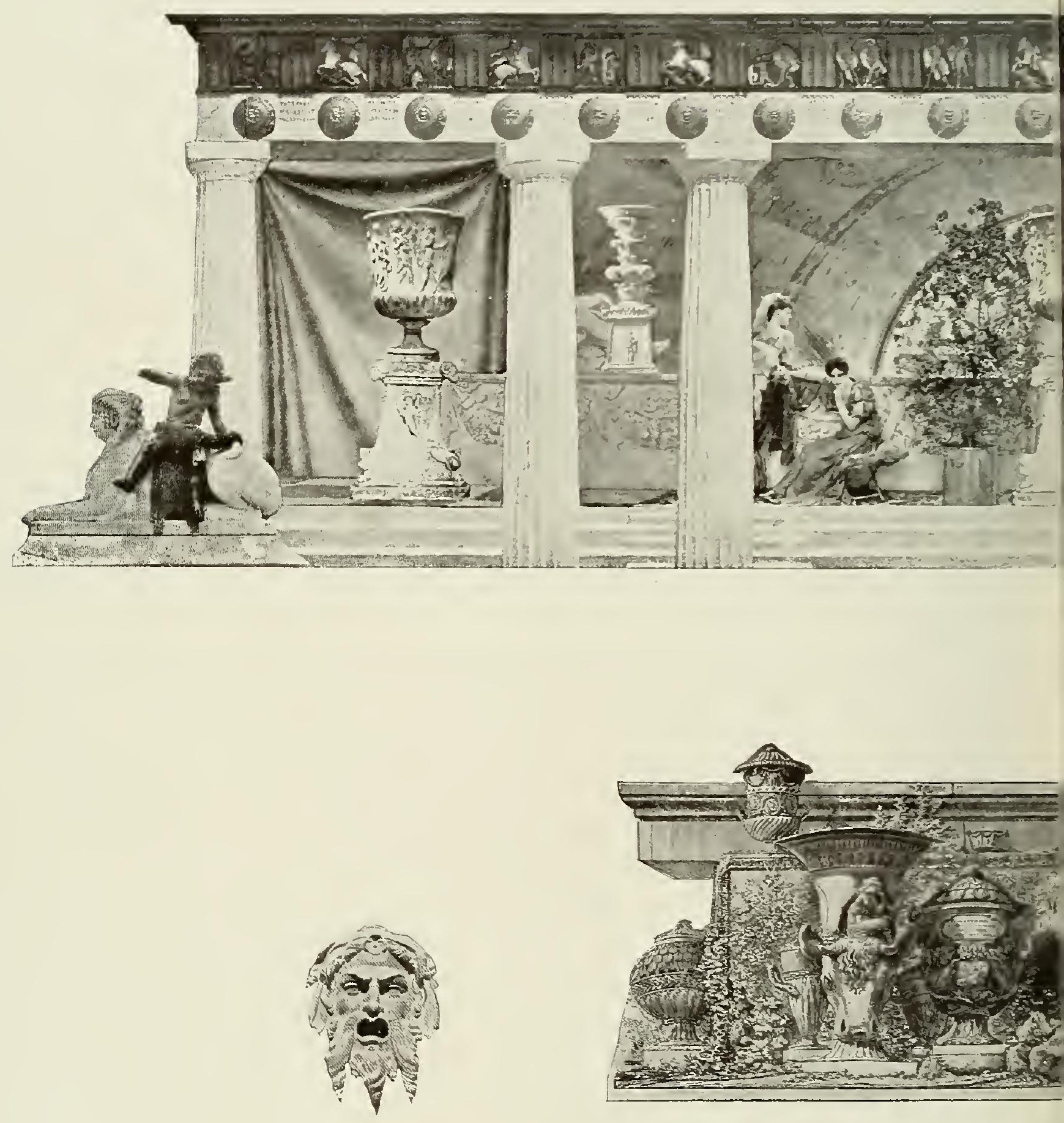

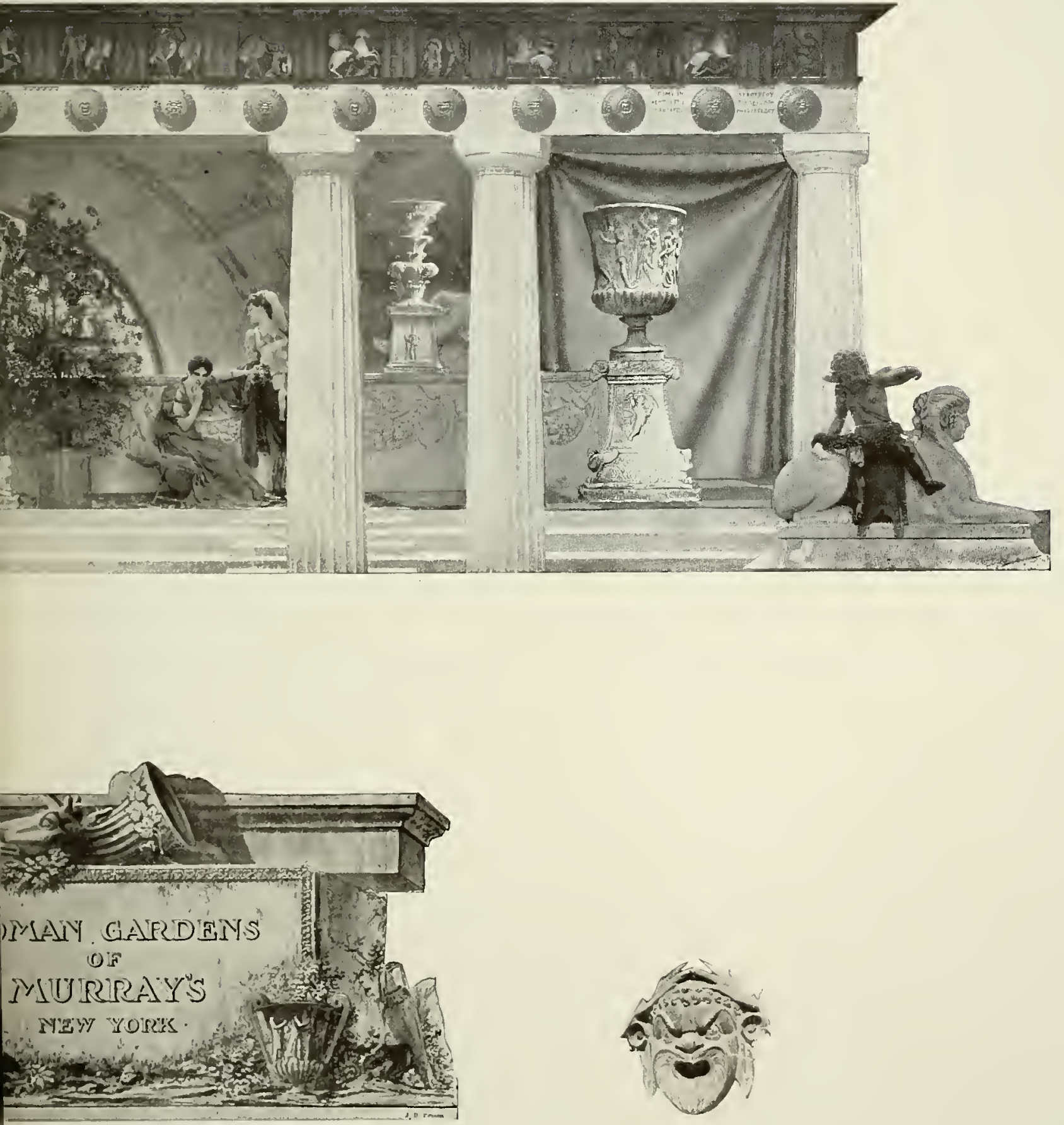



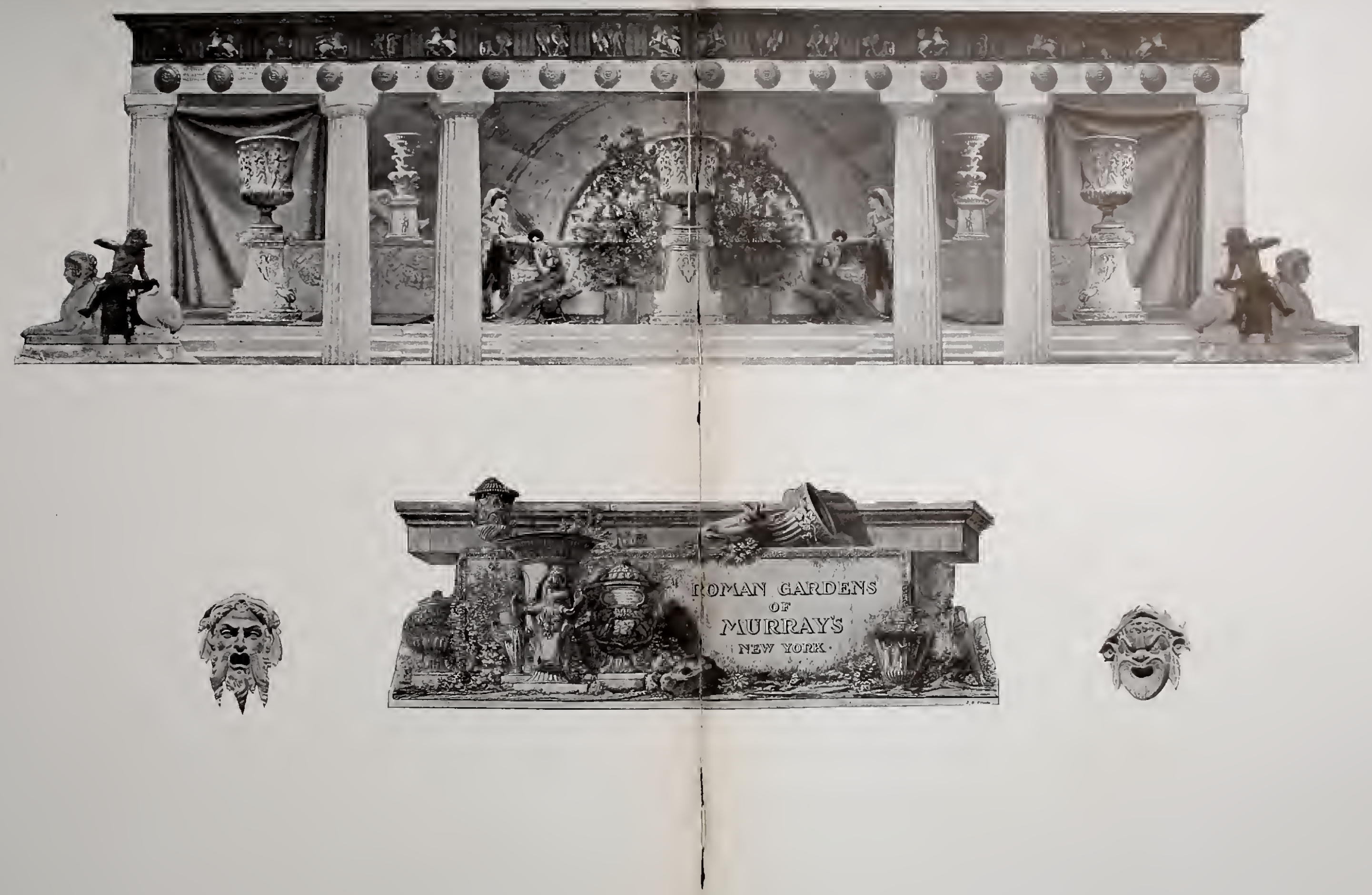




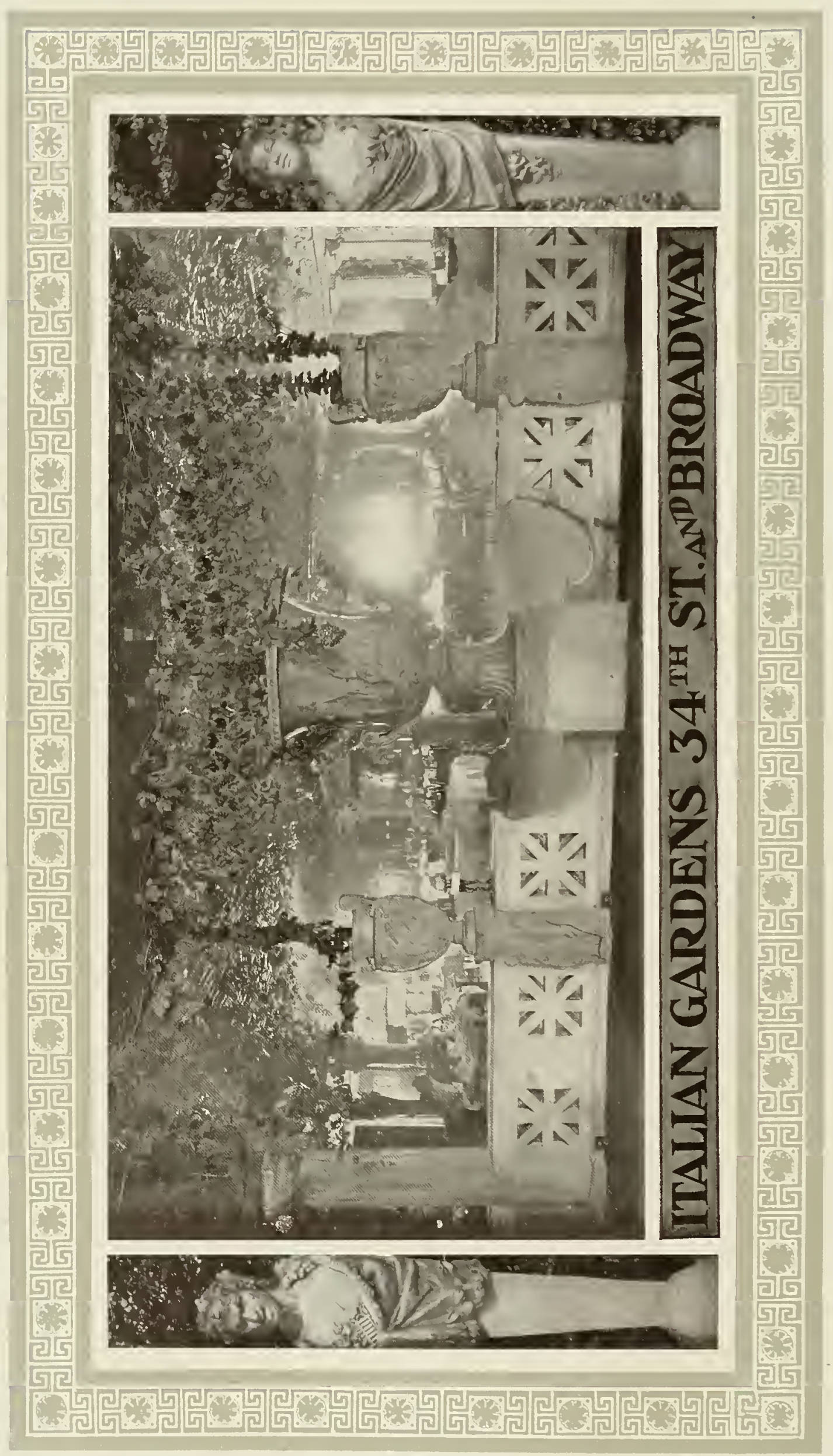




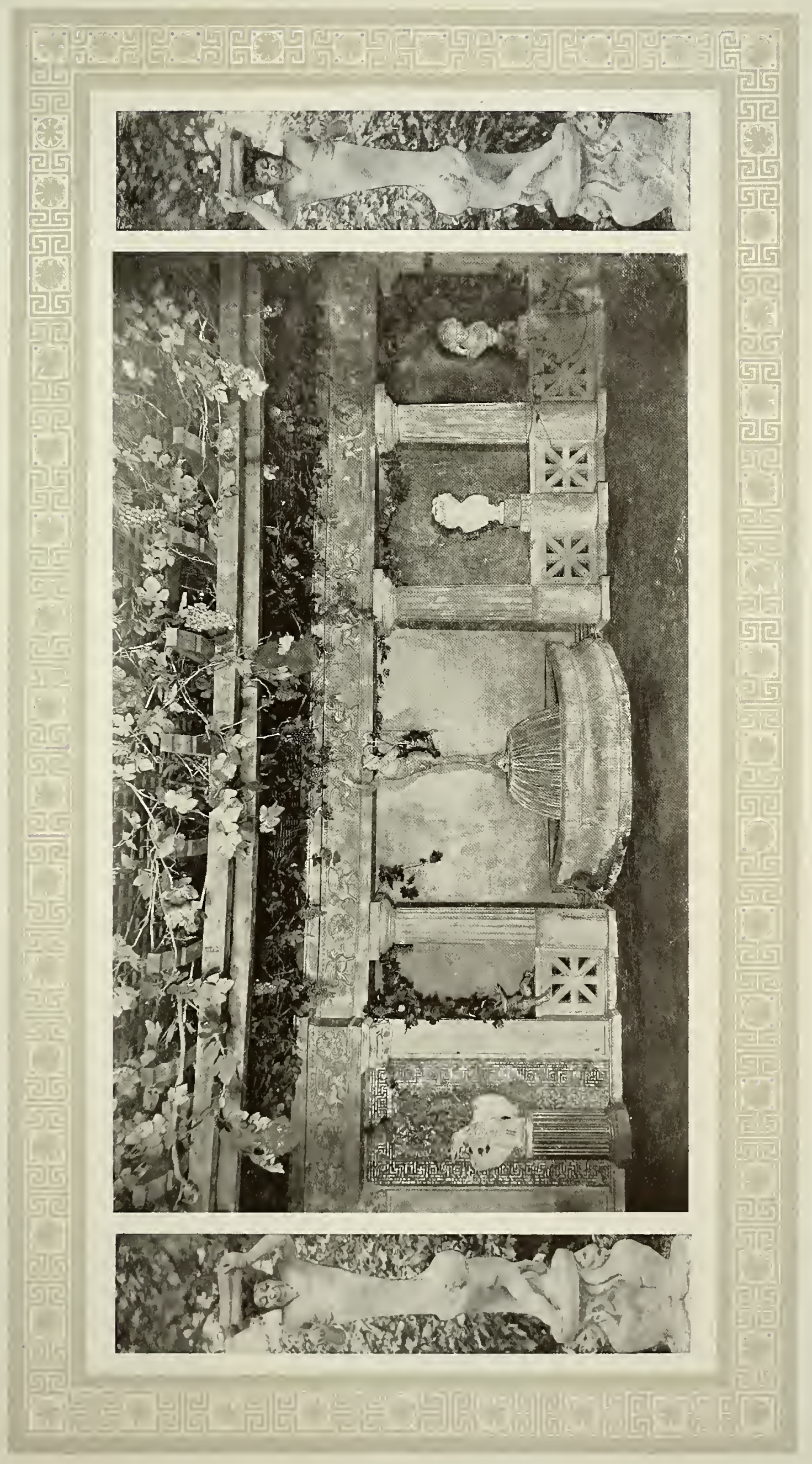

䓪 

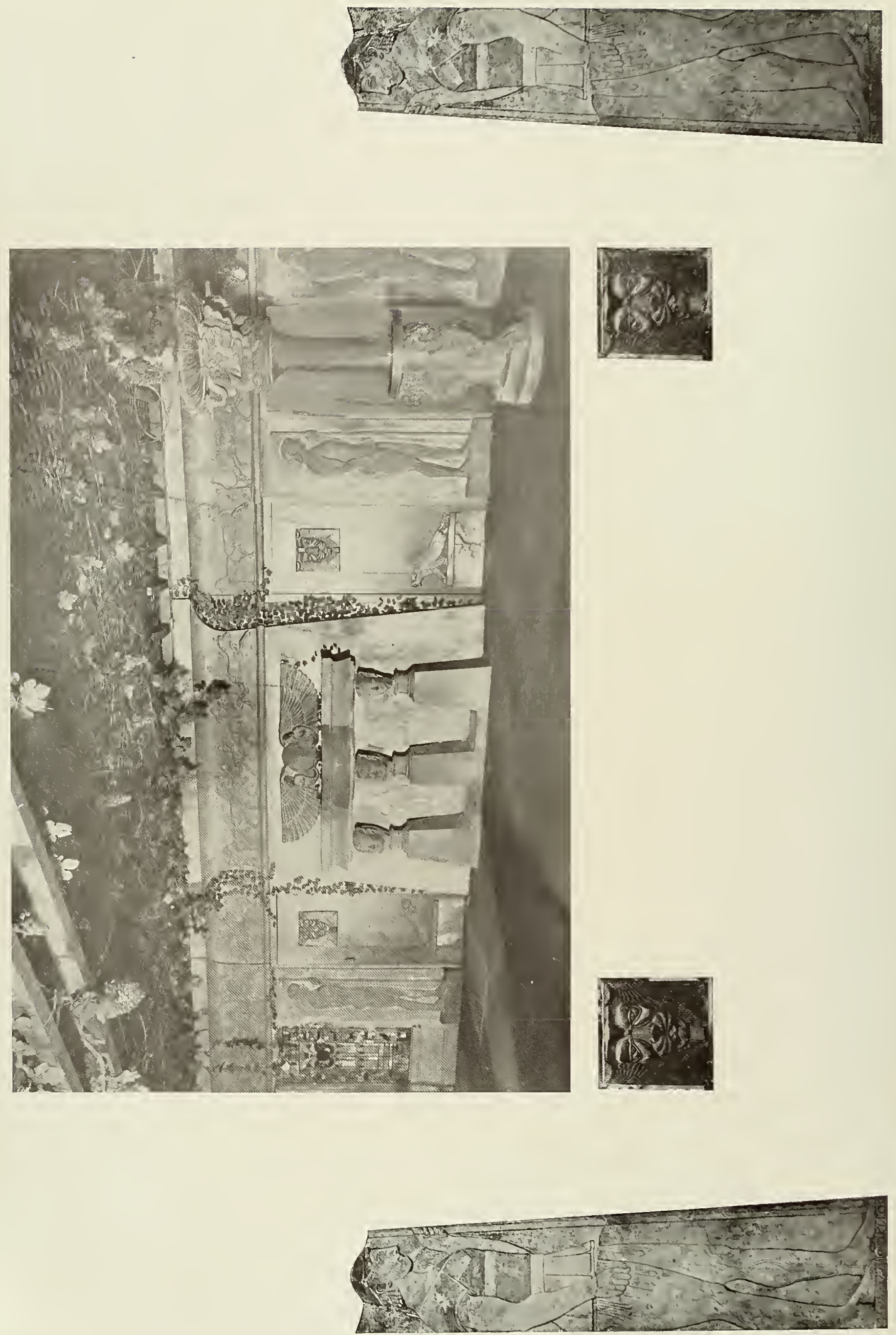


\section{You reill admit}

that unless the "GILLETTE" possessed many points of superiority it never would have been accepted by two million men in the past three years as the best, most simple and satisfactory shaving device in this world.

In the first place my razor requires NO STROPPING, NO HONING.

It is always ready. That's why it's the most practical. You can shave in three to five minutes.

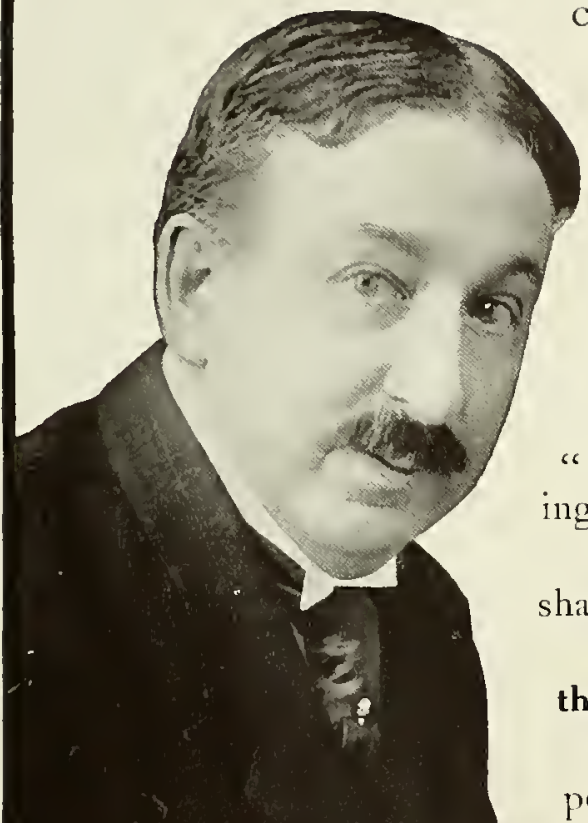

The thin, flexible, double-edged blades remove a harsh or soft beard with perfect comfort. No pulling, cutting or irritation of the skin. They are so inexpensive that when dull you throw them away as you would an old pen. No other razor so durable. The triple silver-plated holder lasts a lifetime. None so convenient; the compact little case can be with you always-if travelling, either in your pocket or grip.

I know men who have shaved in the dark with the "Gillette." Many use it on the train, others while on hunting trips, fishing expeditions, etc.

That's the beauty of my razor, you can obtain a perfect shave under all conditions - wherever you are.

And I will guarantee you will agree with me right nowthat my razor just fits your case. A trial will prove it to you.

Action must accompany right thinking or you have no power of execution.

Put this correct line of thought into action. Get a "Gillette" to-day. All Jewelry, Drug, Cutlery, Hardware and Sporting Goods dealers sell it.

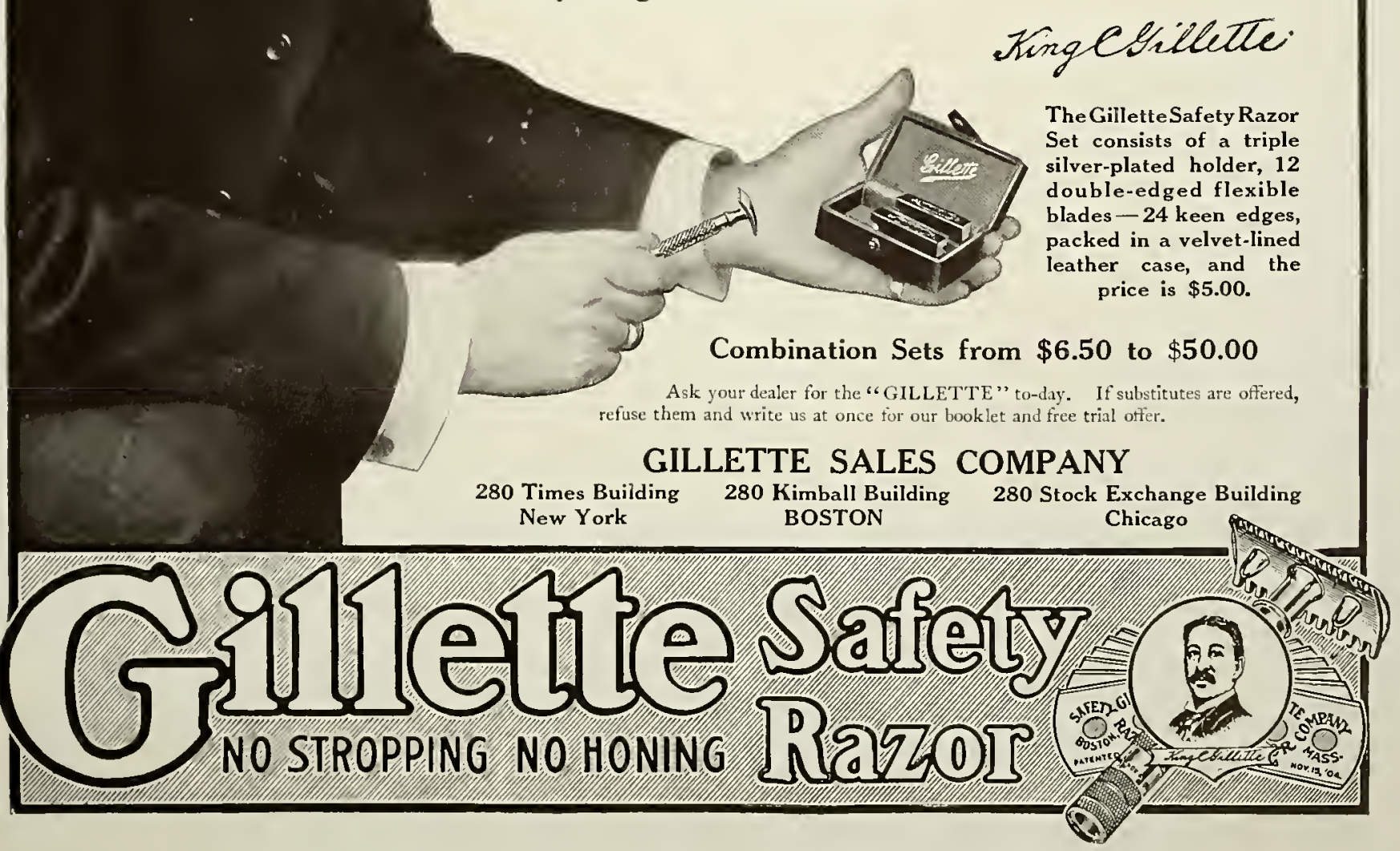


FRIEDRICH KROTE. COBLENZ, ON-RHINE-AND-MOSELLE Chipper of high grade khine and Moselle Wines (still and sparkling) CUNLIFFE. DOBSON \& CO., BORDEAUX. Slippers of high made Clarets and Sauternes, also

5. LHOTE, FILS, DIJON Proprietor of some of the choicest rewths in the Burgundy district, and shipper of all grades, red and white, still and sparkling, "Green Seal " J3urgundies. PLANAT \& CO., COGNAC. Shippers of pure Cognac Brandies ERNST L. ARP, KIEL. Arp's Celebrated Stomach Bitters

P. GARNIER ENGHIEN-LES-BAINS, Distiller of the finest

P. GARNIER ENGHI

HILLS\& UNDERWOOD, LONDON, Celebrated Clobe Brand Sloe Gin All the above goods are obtainable at

MURRAY'S, WEST 42D STREET. NEW YORK CITY

Everything Ready-made and to order for the Kitchen

\section{Walter J. Buzzini}

\section{MANUFACTURER}

419 West Forty-second Street, NEW YORK

Near Ninth Avenue Telephone 931 Bryant

REFRIGERATORS, GENERAL REPAIRS, RETIVNIYG, FTC FRTNCH RAVGFS,

BROILERS ELECTRIC GRILLS

BROILERS. ELECTRIC GRILLS.
EXPERT ON KITCHEN LAYOUT

SPECIFICATIONS FURNISIIED

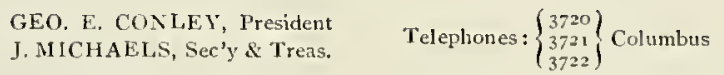

\section{Geo. E. Conley Company}

WHOLESALE DEALERS AND DIRECT RECEIVERS OF ALL KINDS OF

F resh and Salt Water F ish

56th Street and Eighth Avenue New York City

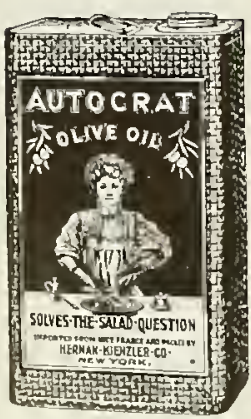

HermanK ienzlerCo.

Pressers and Importers of

French and Italian Olive Oil

22 Desbrosses St. $457-463$ Greenwich St. NEW YORK
B I R RH W T E

THE GREAT FRENCH

TONIC AND APPETIZER

MERRY WIDOW COCKTAIL

HALF BYRRH WINE $\therefore$.

HALF DRY GIN NO BITTERS

DUBOIS FRERES \& CAGNION $\therefore$ B R A N D I E S $\dot{C}$ C A G N A E, F R A N C E VANDULKIN WEILAND \& CO. $\begin{array}{llllllllllllll}H & O & L & L & A & N & D & G & \text { I } & N & S\end{array}$ ROT TERDAM, HOLLAND J. G. ROSE, A G EN T 1109 TIMES BUILLDING, NEW YORK

\section{PAUL JONES \& CO.}

DISTILLERS

\section{LOUISVILLE, KENTUCKY}

Incorporated 1895

BEAKES DAIRY COMIPANI' Producers Wholesale and Retail Dealers in MILK AND CREAII Manufacturers of Condensed and Evaporated Milk
Special attention given to supplying hotels and private families BOTTLED MILK A SPECIALTY

206 East 12th Street New York City Branches: 420-43I West 53rd Street 1311 Amsterdam Arenue SHIPPED TO ANY POINT BI BOAT OR RAIL

W. I, LEEDS

Established is 70

F. H. PALMER

BURCHARD \& CO.

T eas, Coffees and Chocolates 265 Washington Street

Telephone: 4912 Cortlandt

NEW YCRK

\section{Telephone: $28_{3}$ Plaza}

\section{First Vienna Bakery}

Wholesale Bakers

Special Attention Given to Hotels, Restaurants, Steamships and Institutions

Factory and Office: 231 and 233 East $6+$ th Street NEW YORK 


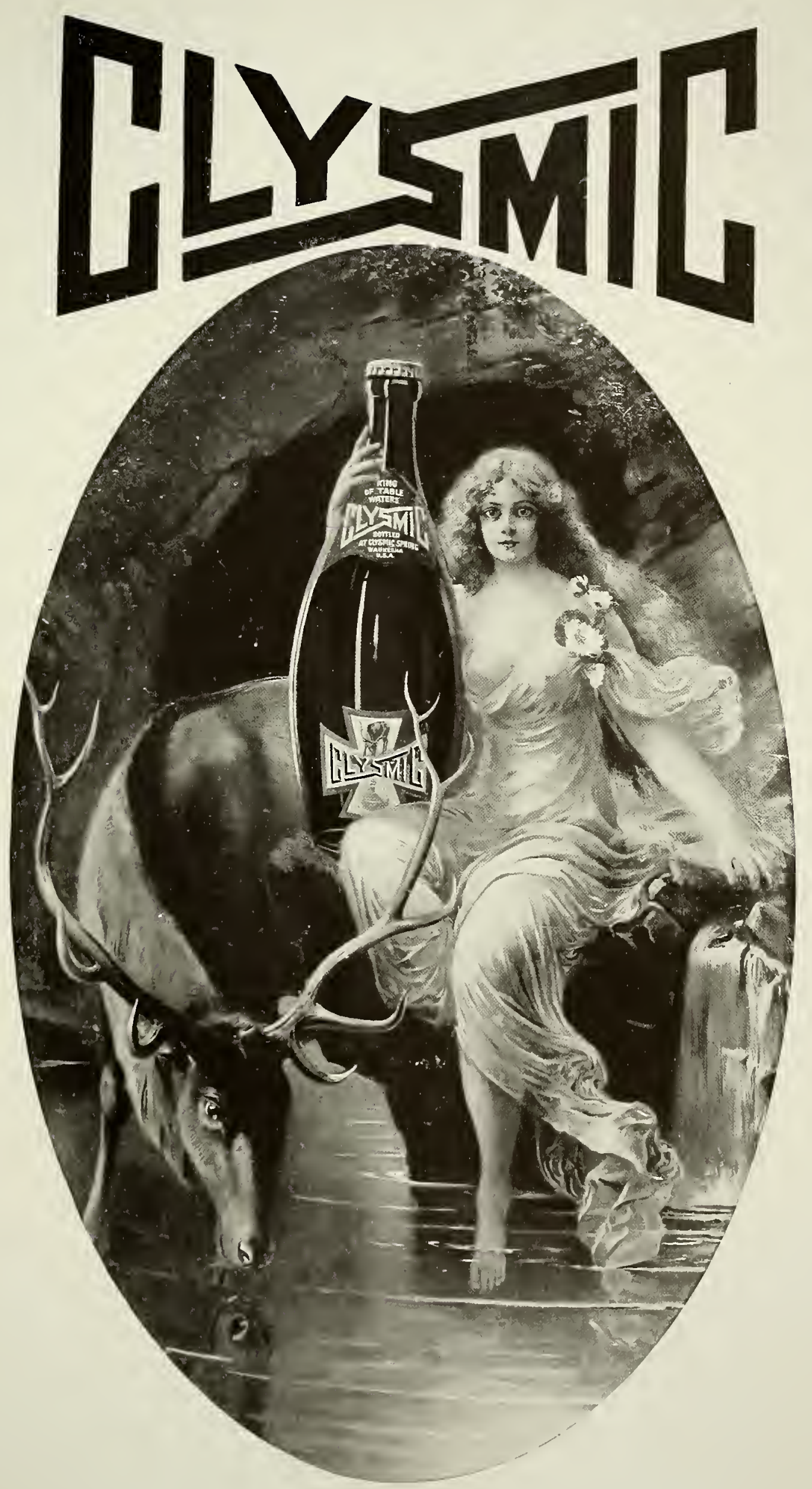

The Management takes pleasure in recommending "CLYSMIC WATER" to its patrons._" "MURRAY'S" 


\section{Seamen Lichtenstein Eै Company}

High Grade Vegetables and Fruits

$81 \& 83$ Barclay Street

New York City

Hot-House and Imported Vegetables

Cultivated Mushrooms and Cantaloupes

Hotels, Restaurants

Clubs, Steamships

Groceries and

Markets Supplied

Established 1857

Geo. M. Still, (Inc.)

Planters of, Wholesale Dealers in and Shippers of

\section{Oysters and Clams}

Boat No. 12, Foot of Bloomfield St. New York

Selected Half She!l S:ock and Native Little Neck Clams our Specialty

H. B. DAY CO.

Hotel and Club Supplies

357 West 44th Street, New York

Olives

Cooking Oil

Capers

Pickles

Vinegar

Syrups
Telephone $\left\{\begin{array}{l}828 \pi \\ 8282\end{array}\right\}$ Cortlandt

\section{JOHN W. BUTLER \\ Butter, Cheese and Eggs}

2 I6 Washington Street NEW Y ORK

Fancy Elgin and Philadelphia

Creameries a Specialty : : : :

\section{WASHINGTON STREET NEW YORK}

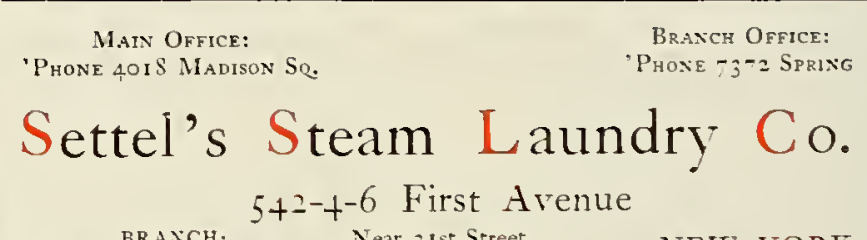

BRANCH:

7-9 BEDFORD STREET Near 31 st Street

NEIT YORK Near West Houston Street

Hotel, Steamship and Restaurant Work Solicited. Satisfaction Guaranteed

\section{LOBSTERS}

Direct from the ocean to vour chef. Carefully selected and packed with sea-weed in our refrigerator package. No ice or fresh-wa'er can touch them. They arrive alive and retain all that delicious flavor natural to a lobster when eaten fresh from the ocean. HIGH.CLASS RESTAURANTS AXD HOTELS, ANYWHERE IN THE UNITED STATES, SUPPLIED DIRECT

THORNDIKE \& HIX

East Boston, Mass. Incorporated Rockland, Maine 


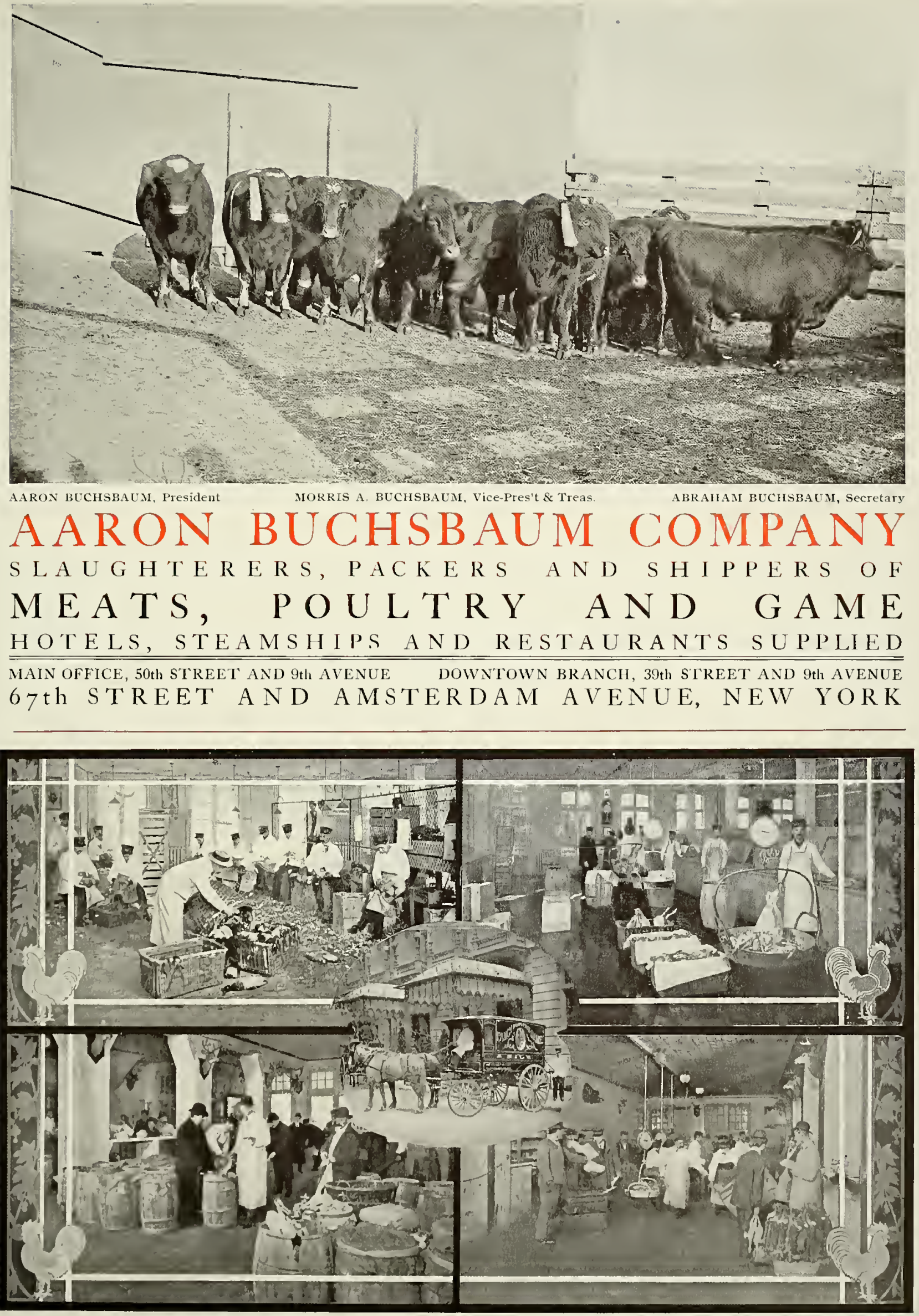

The New World's Palatial Market for the distribution of Poultry and Game

\section{A. SILZ, 414-18 W. 14th St., New York}

THE patronage of this model establishment is exclusive yet extensive. It includes New York's leading hotels, restaurants and clubs, as well as the principal transatlantic steamship lines entering this port. It extends to high-class hotels in cities and summer resorts outside. Orders may be made by mail or wire with assurance of prompt and satisfactory treatment, or a representative will call upon request. 


\section{THE CENTURY BANK}

OF $\mathrm{TH} \mathrm{H}$

\section{CAPITAL, $\$ 200,000.00$ \\ HARDEN L, CRAWFORD \\ President \\ HENRY DIMSE \\ ARTHUR H. DAY'TON \\ Vice-President}

CITY OF NEW YORK

FIFTH AVENUE AT 2OTH STREET

BRANCH: BroadWAY AT 104TH STREET

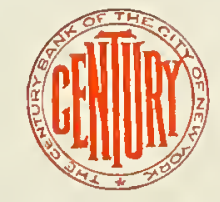

SURPLUS, $\$ 144,000.00$

C. STANLEY MITCHELL Assistant Cashier

WILLIAM D PIKE

THEODORE S. FULLER
Assistant Cashier

This Bank is Conservatively Managed along the lines of good banking.

Accounts of Bankers, Merchants, and Individuals are solicited.

We invite personal interviews or correspondence from those who contemplate opening a bank-account, and Special Attention will be paid to Out-of-Town Accounts.

This $\mathrm{B}_{\text {Ank }}$ is designated a Depositary for the funds of the State of New York and City of New York.
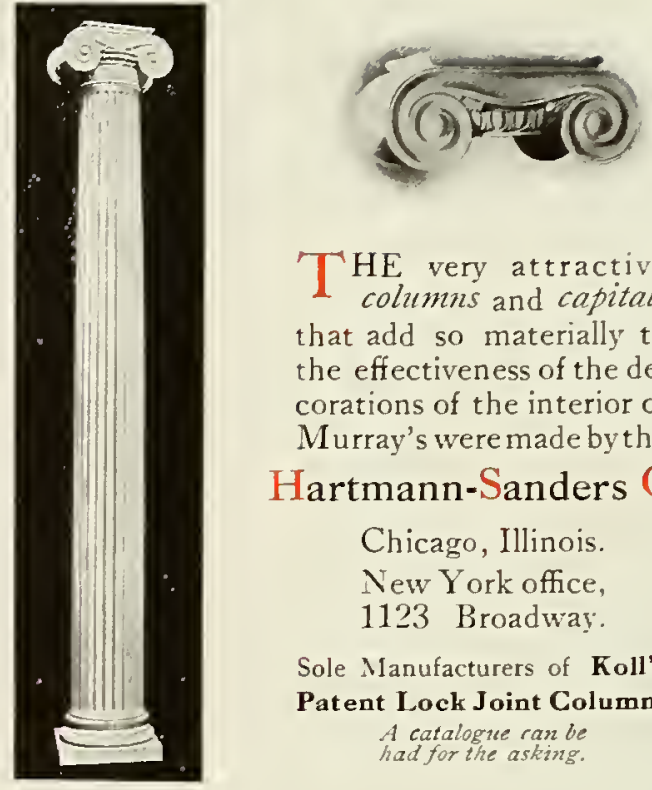

$7 \mathrm{HE}$ very attractive columns and capitals that add so materially to the effectiveness of the decorations of the interior of Murray's were made by the Hartmann-Sanders Co.

Chicago, Illinois.

New York office,

1123 Broadway

Sole Manufacturers of Koll's Patent Lock Joint Columns A catalogue ran be
had for the asking.

\section{(0) he $\mathbb{O x p a r a t o r ~ r e g e n e r a t e s ~ i m p u r e ~ a i r ~}$}

Natural system of inner air ventilation. The functions of the Oxygators are based upon the properties of the chemical "Oxone" to absorb carbonic acid gas and the poisonous parts of air and to generate Oxygen. The Oxygator regenerates foul air follow. ing the law of nature that oxygen gas purifies, disinfects and deodorizes.

The Oxygator sucks the foul air in by a powerful blower run by a small motor. The socket of one ordinary incandescent lamp supplies all power.

The foul air is compressed in an inner air pressure chamber. In this hangs a wire basket to hold the Oxone. When foul air strikes this chemical it gives off pure Oxygen which kills the germs.

The air after undergoing this chemical purification is whirled through the water below the air chamber, where it is mechanically washed. The regenerated air is then thrown into the room absolutely pure and with its temperature lowered by an average of 10 degrees.

1. It renders ventilation independent of an outside air supply, thus insuringa steady control of temperature

2. It secures a stable, standard composition of air in the hygienic state as provided by Nature, even with a surplus of Oxygen.

A necessity in hotels and restaurants. Most important to all restaurants and hotels.
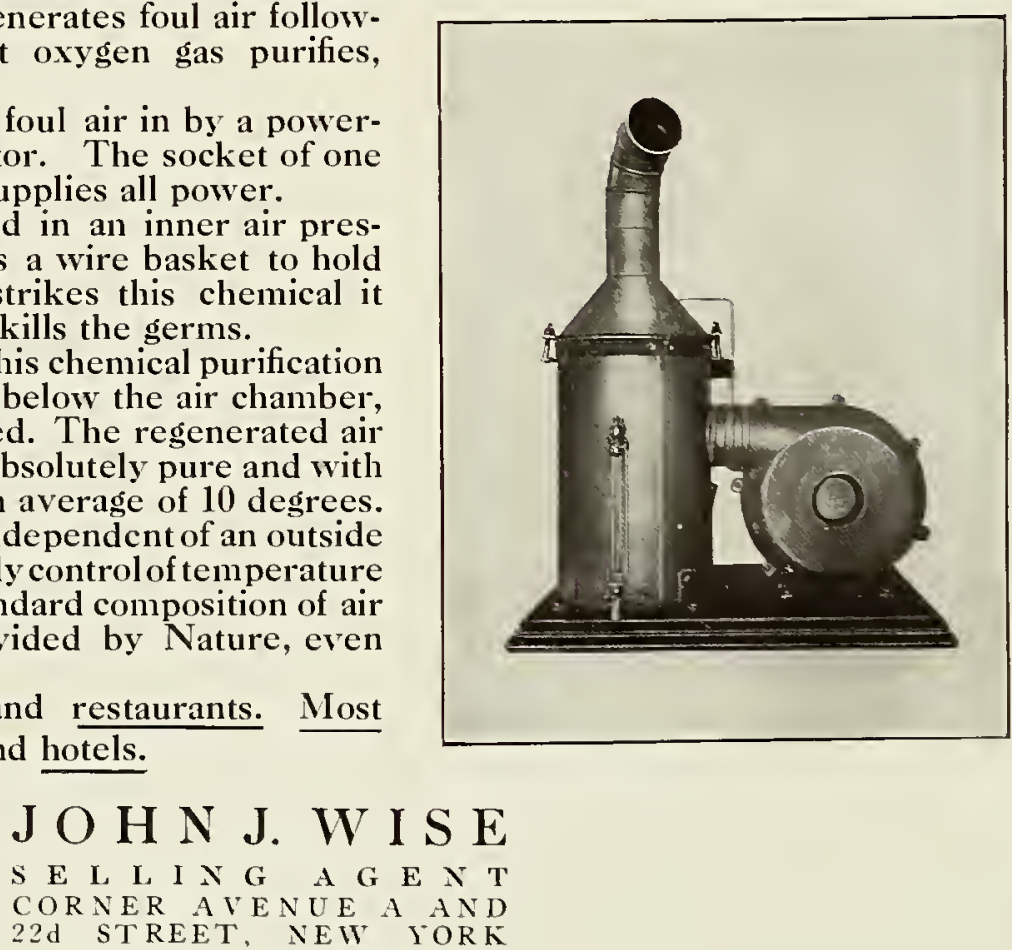
AYALA \& CO., "Magnet Brand" The Premier CHAMPAGNE of the World. Endorsed by the leading Clubs, Hotels, and Restaurants of Europe and America : : :

\section{A. H. MEYER COMPANY H O B O K E N, N E W J E R S E Y

From the Fishery to Murray's Always Fresh :: :: :: ::

\section{RUSSIAN ROMANOFF CAVIAR}

It is the best, most delicious, stimulating and refined delicacy that can be served at Luncheon, Dinner or Supper Parties : :

Russian Caviar Co. 291 Fifth Ave. 155 Reade Street And all Bust stores.

\section{Contributor Cigars are always smooth}

The secret is that the tobaccos used are always mellow

UR maturing and blending
process, needs at least four months' time, takes away all the raw spots, common in the finest Havana. I A Cigar cannot be smooth unless mellow. I The Contributor is all Havana-inside and out.

\section{American Exchange Cigar Company, Manufacturers 208 E. Twenty-Seventh Street, New York}


McCUE BROS. \& DRUMMOND

Unequalled Hats

Knapp Felt De Luxe

Derby - - $\$ 6.00$

Sylkfelt Something new in the way of Imported Hats. The

best derby made in England. -

Sold in New York by us only $\$ \mathbf{5 . 0 0}$

The Drummond Derby $\$ 3.50$

$$
\begin{aligned}
& \text { I } 442 \text { Broadway } \\
& \text { Bet. } 40 \text { th and } 41 \text { st Streets } \\
& 52-54 \text { New Street } \\
& \text { Below Stock Exchange }
\end{aligned}
$$

BROADWAY STORE OPEN EVENINGS

FRANK WEINBERG
FLORIST,

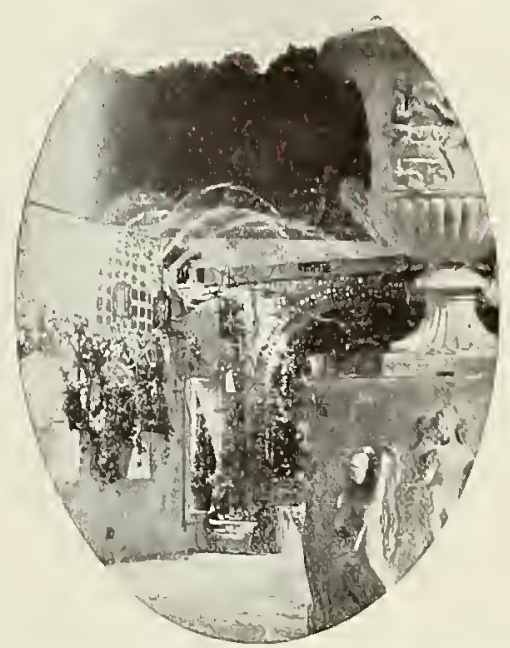

SEND FOR ILLUSTRATED CATALOGUE ESTIMATES GIVEN FOR INTERIOR AND EXTERIOR GARDENS AND SPECIALTY OF HOTELS AND RESTAURANTS

\section{BLACK DIAMONDS}

\section{COMIONLY KNOWN AS ANTHRACIIE COAI,}

For Hotels, Apartment Houses, Restaurants and private residences, can be secured, to the entire satisfaction of the
consumer, by placing the bisiness in the care of the undersigned, whose attention to the orders placed with him insures full weight, good quality and prompt delireries.

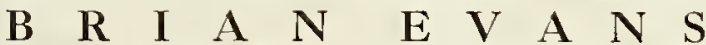
Telephone 110 Courtlandt 143 LIBERTY STREET
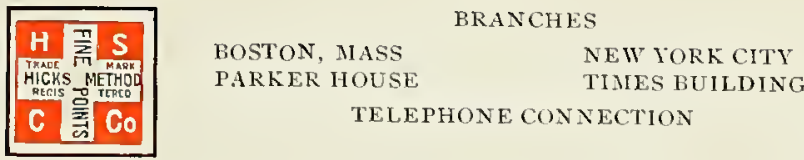

\section{HOTEL SECURITY CHECKING CO.}

'TIE H'IOXEERS OF IIOTEL AYI RESTAURAN'T CONTROL
MEDFORD MASSACIUSETTS
From the $($ when Helmholtz approved its scientific construction, Days. $\{$ when Rubinstein strings, divine harmonies from (when W a $\mathrm{g}$ n e r the inspiring beauty of its tone,

\section{THE STEINWAY PIANO}

Has Been Continuously Without a Peer in the Musical World IT IS USED IN THIS HOTEL EXCLUSIVELY. IXSPECTION INYITED STEINWAY \& SONS, STEINWAY HALL Subway Express Station at the Door

Telephone Connection

\section{S. HOFFMAN}

Constructor of fine garments for men who know what's what.

233 Broadway, New York

Opposite Post Office

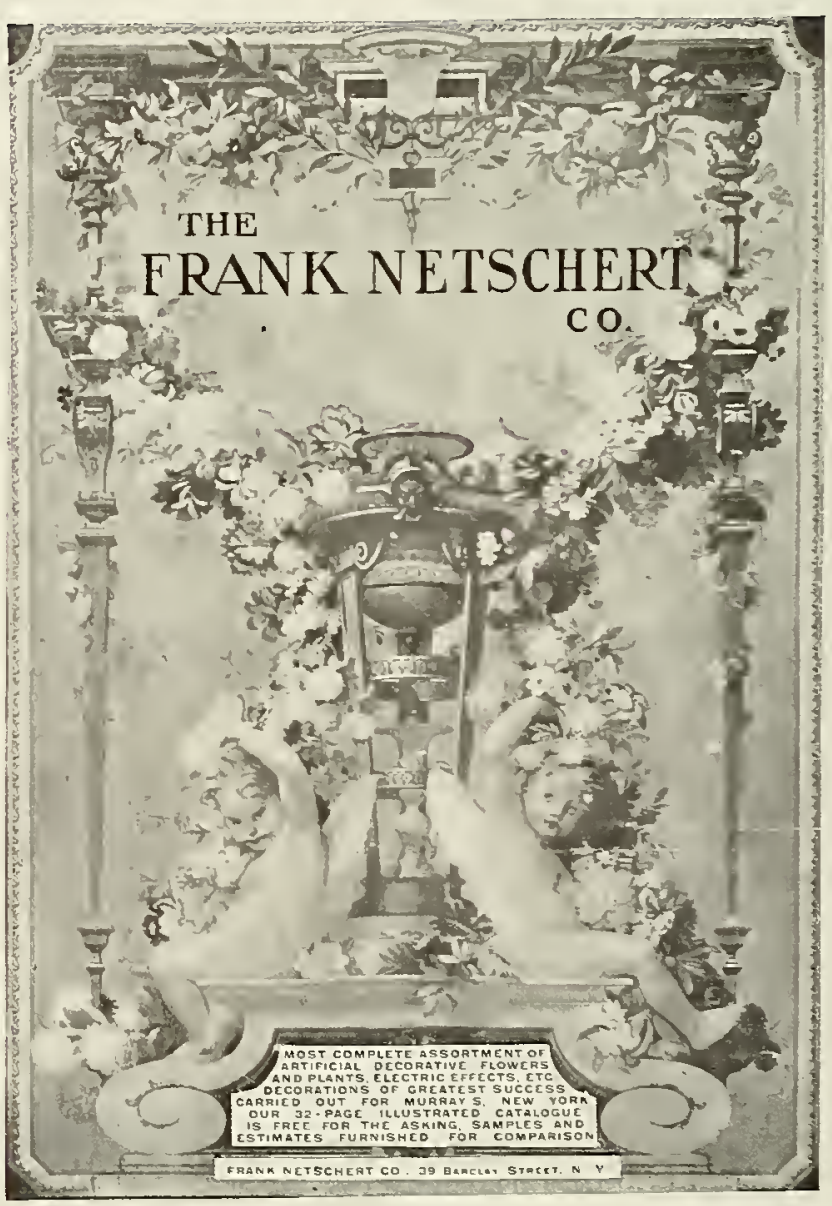

Telephone: $1 \$ 65-J$ Melrose

\section{FRANK McCULLOUGH}

Wholesale and Retail Dealer in

\section{CHARCOAL}

286-288 EAST 141ST STREET, BRONI NEW YORK 
Hours: IO-10

\section{Mme. C. Terry Swedish Institute}

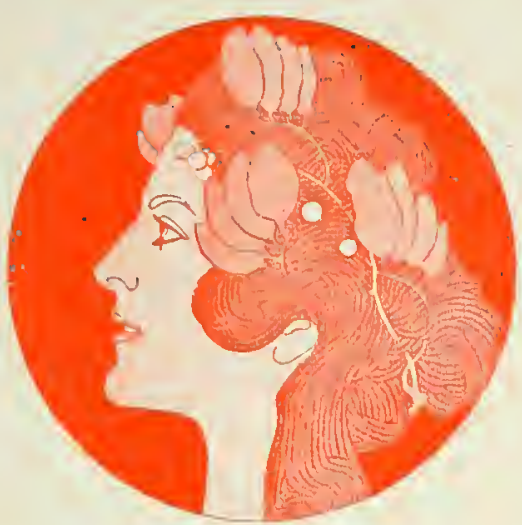

- Scientific Massage and Manicuring. Baths; Hot, Cold, Tub, Pine-Needle and Vapor. 2 I 2 West Forty-second Street, Near Broadway, New York

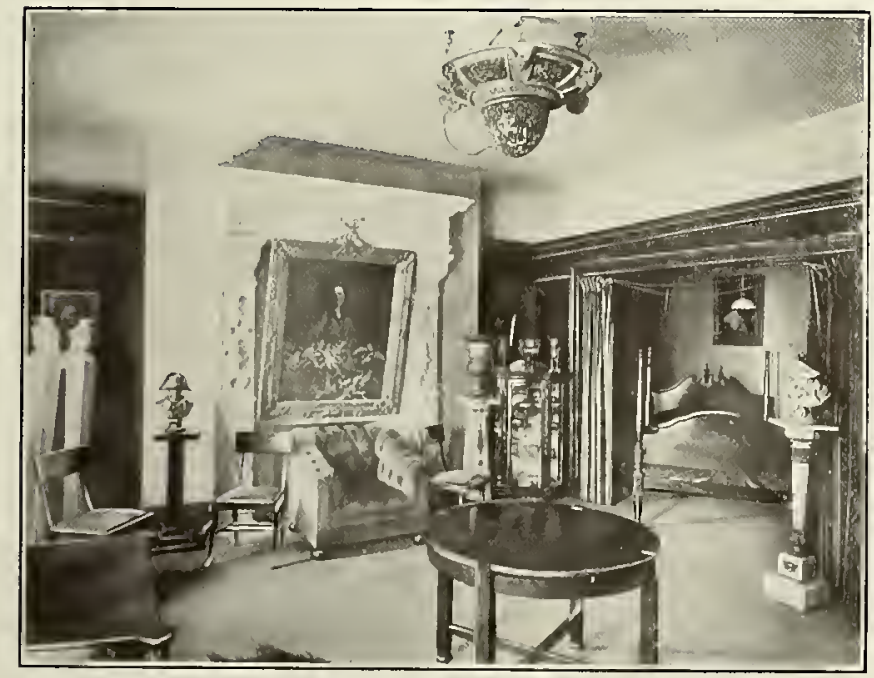

“MURRAY'S" WAS DECORATED, FURNISHED AND EQUIPPED BY THE FIRM OF STERN BROTHERS WEST TWENTY-THIRD STREET
HIGGINS \& SEITER
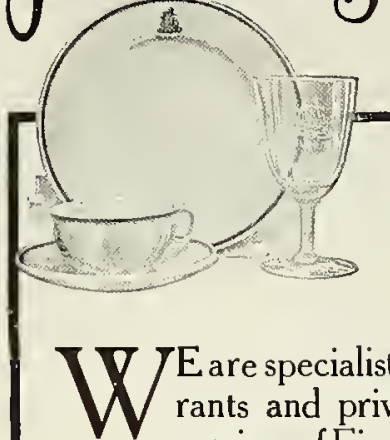

THE LARGEST CHINA A*O GLASS RETAILERS IN THE WORLD.

V JEare specialists in supplying hotels, restaurants and private families with complete services of Fine China and Rich Cut Glass.

Our facilities for decorating these wares with names, crests or monograms are unexcelled. We have a large decorating plant on the premises.

An example of our decorative work is herewith illustrated. It represents pieces of china and glass from the service especially decorated and furnished complete to Murray's Restaurant, where we also supplied much of the Choice Bric-a-Brac, Oil Paintings, etc.

Our Mail Order Department is well-establıshed and far-reaching. Orders from distant points are filled promptly and accurately. Satisfaction guaranteed. Our prices average "1-4 Less than Elsewhere."

"BUY CHINA AND GLASS RIGHT"

West 21 st and West 22d Streets Just East of Sixth Avenue

\section{H. W. Baker Linen Co.}

IMPORTERS OF LINEN

$M A N U F A C T$ T E R S OF SHEETS AND PILLOW CASES

WHOLESALE DEALERS IN BLANKETS, BEDDING, ETC.

76 Franklin Street, New York

Direct Importers of linens for hotels, restaurants, institutions, railways, steamships, etc. I Names, crests, monograms, etc., woven in all kinds of linens.

All the linen for Murray's was furnished by us Telephone, $\left\{\begin{array}{c}5264 \\ 5265\end{array}\right\}$ Franklin 


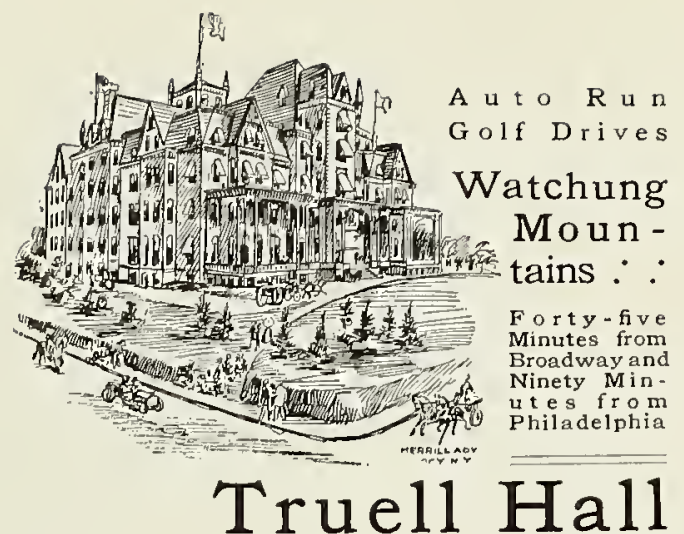

Pla infield, $N$ e w Jersey

Formerly Hotel Netherwood

An Ideal Summer Home. Open all Year Erected at a Cost of One Half Million Dollars. Three Minutes from Station TEN ACRES OF BEAU DFY NOT TOO HOT, NOT TOO COLD, JUST RIGH AMIDST JERSEY'S PICTURE LANDS

Healthful Climate Excellent Views
Also Truell Inn and Truell Court Send for Booklet and Rates

\section{STOP AT THE HOTEL PONCE DE LEON \\ WHEN AT \\ ATLANTIC CITY}

Virginia Avenue and the Beach

The Hotel Ponce De Leon is newly furn ished throughout with rare taste, and pos sesses all modern requisites for convenience

European and American Plan.

A BOOKLE'T will be gladly furnished upon application.

Rates, Running from $\$ 12,50$ to $\$ 30,00$ per week, according to location of the rooms.

For further information, address

ALFRED B. GRINDROD,

Atlantic City. N. J.

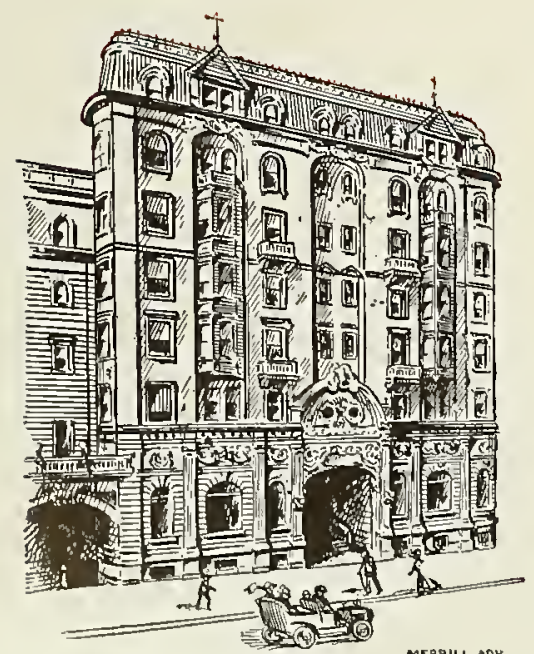

\section{RICHMOND}

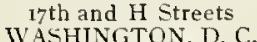

OPEN AIT TON, D. C.

700 Rooms, 50 Private Baths,

American Plan. \$3.00 per Day ditional, European Plan. $\Sigma_{1.50}$ per Day, Upwards; with Batly. $\$ 1.00$ Additional.

A High-class Hotel. conducted for your comfort. Directly on car line. Union Station, 15 minutes. Capitol, 15 minutes. Two blocks to White House Tho blocks to White House posite Metropolitan Club

Summer Season, July to Oct.

Wayside Inn and Cottages.
Lake Luzerne, N. Y., in the

Adirondacks. Switzerland of America ;
Saratoga.

meamil ary Clifford M. Lewis, Prop.

\section{HOTEL KERNAN}

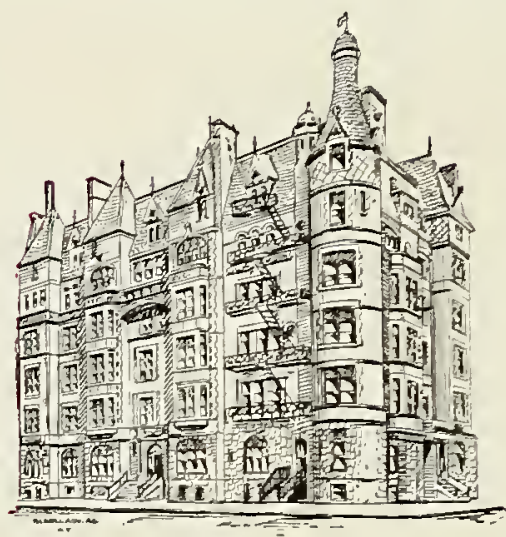

European Plan

Absolutely Fireproo

In the Heart of the Business

BALTIMORE, MD.

Luxurious Rooms

Single and En Suite

With or Without Baths

\$I.00 Per Day UP

Palatial Dining Rooms

Unsurpassed Cuisine

Shower and Plunge in

Turkish Baths Free to Guests

Jas. E. Barrett, Manager Send for Booklet

\section{DOREAN HOTEL}

(Brick Fireproof)

Ocean Front and Vermont Avenue

Atlantic City, N. J.

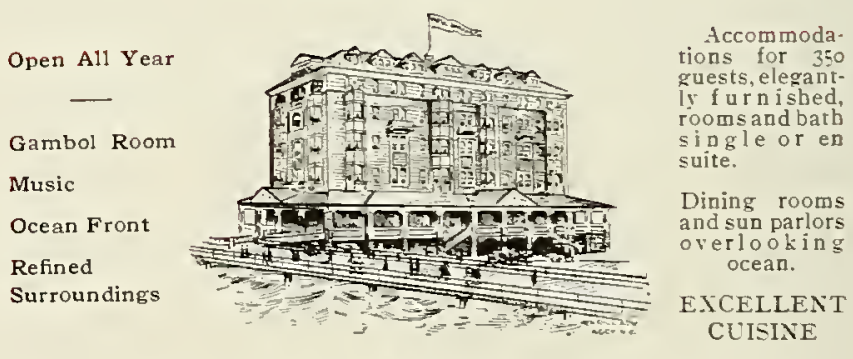

NEW GRILLE \& LA AMERICA

Billiards, Shuffle Board, Etc. Music. Write for literature.

E. E. MORALL, Proprietor

\section{HOTEL WESTMINSTER} IRVING PLACE New York City

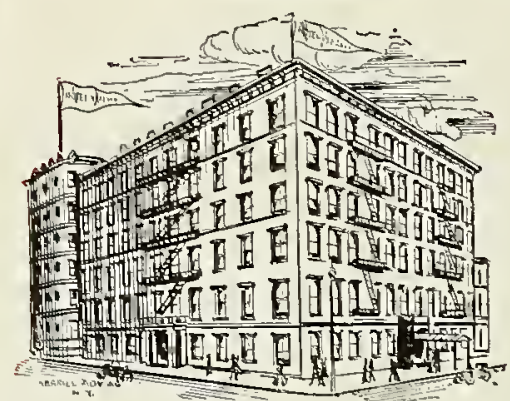

One block from Ĺnion Square. Surface, Elevated and Subwa ing Wholesale and Retail stores and Theatres, and yet ar enough fron broadway to from the noise and bustle of PERFECTIY OUIET I cality and HOME-LIKE in every respect. ENCELLENT CUISINE EUROPEAN PLAN

Single Rooms, $\$ 1.00$ per day and up. Room with Bath. \$2.00 per day and up. Parlor. day and up.

American Plan \$3.00 per day and upward. Club Breakfast The Jolan F. Hollingswortl $\mathrm{Co}$.

C. H. GODFREE, Manager 


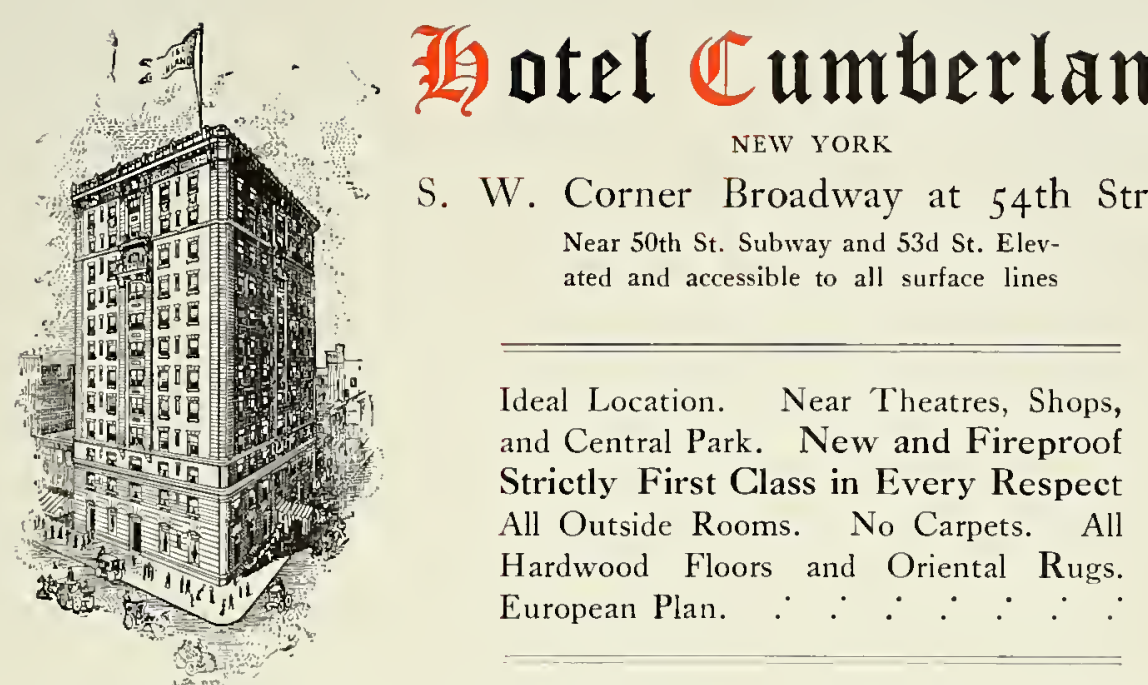

Transient rates, $\$ 2.50$ with bath, and up. $\therefore \quad$ Restaurant unexcelled.

Prices Reasonable. : $\therefore$ Send for Booklet.

HARRY P. STIMSON

Formerly with Hotel Imperial.
R. J. BINGHAM

Formerly with Hotel Woodward.

\section{J esse C. Bennett \& Co.}

ESTABLISHED $\quad 1888$

\section{REAL ESTATE}

Estates Managed. Money

Loaned on Bond and Mortgage

2259 BROADWAY, Cor. 8 ist St. NEW YORK

\section{政otel 迎ayard}

M. FRANK MEEHAN, Proprietor

I 42-I 44-I 46 West 49th Street NEW YORK

TRANSIENT and family hotel; fireproof; 200 rooms, I 50 baths. A well conducted hotel, quiet, yet close to Broadway. Six surface car lines within two minutes walk. Subway and Elevated Railway stations one block away.

Convenient to everything.

Best room values in New York.

Single rooms, free baths, $\$ 1.00$ and $\$ 1.50$

Rooms, with bath . . . . $\$ 2.00$

Parlor, bedroom and bath, . . $\$ 3.50$ 
ERKINS STUDIOS

IO EAST THIRTY-TIIRD STREET

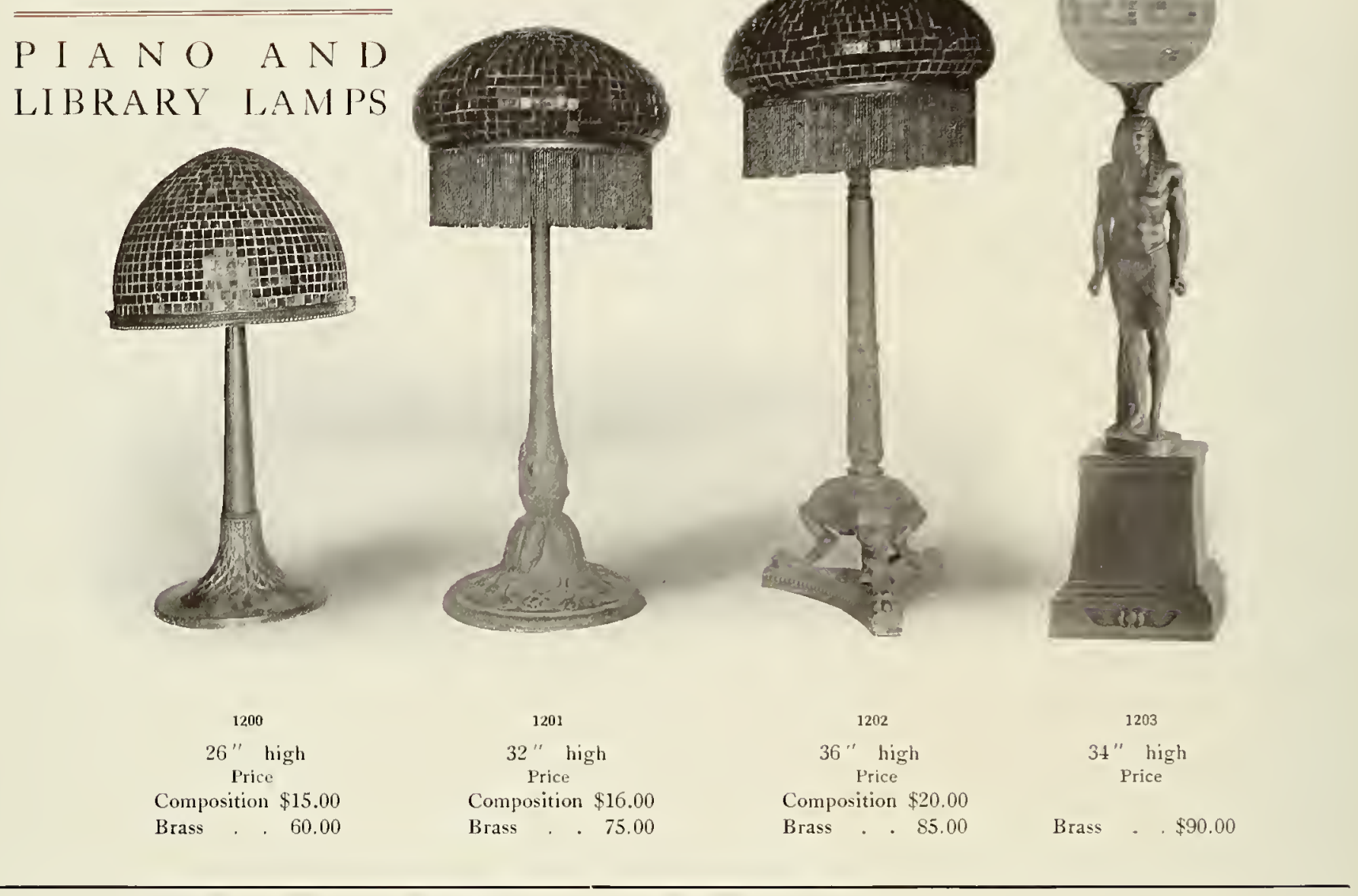

\section{SGA GLIOLINE}

The most perfect fire-proof and sound-proof partition block yet devised. Scaglioline block is made of Plaster of Paris chemicals and the aggregates of well burnt cinders and it produces a partition of absolute fire-resisting qualities. - Scaglioline block has been approved by the Bureau of Buildings in Greater New York, and has successfully withstood all fire tests made at various times by the Commissioner of buildings; official reports of these tests may be inspected at the office of the Company. Architects who specify Scaglioline block secure the high quality of work they desire. Contractors on account of the large amount they can exact per man, save money both ways-erection and first cost. Samples and estimates furnished on application, also references from parties who have used scaglioline block.

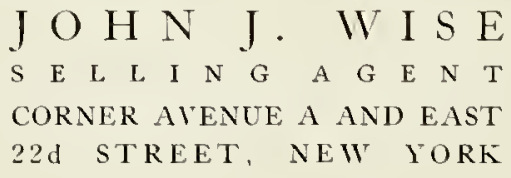



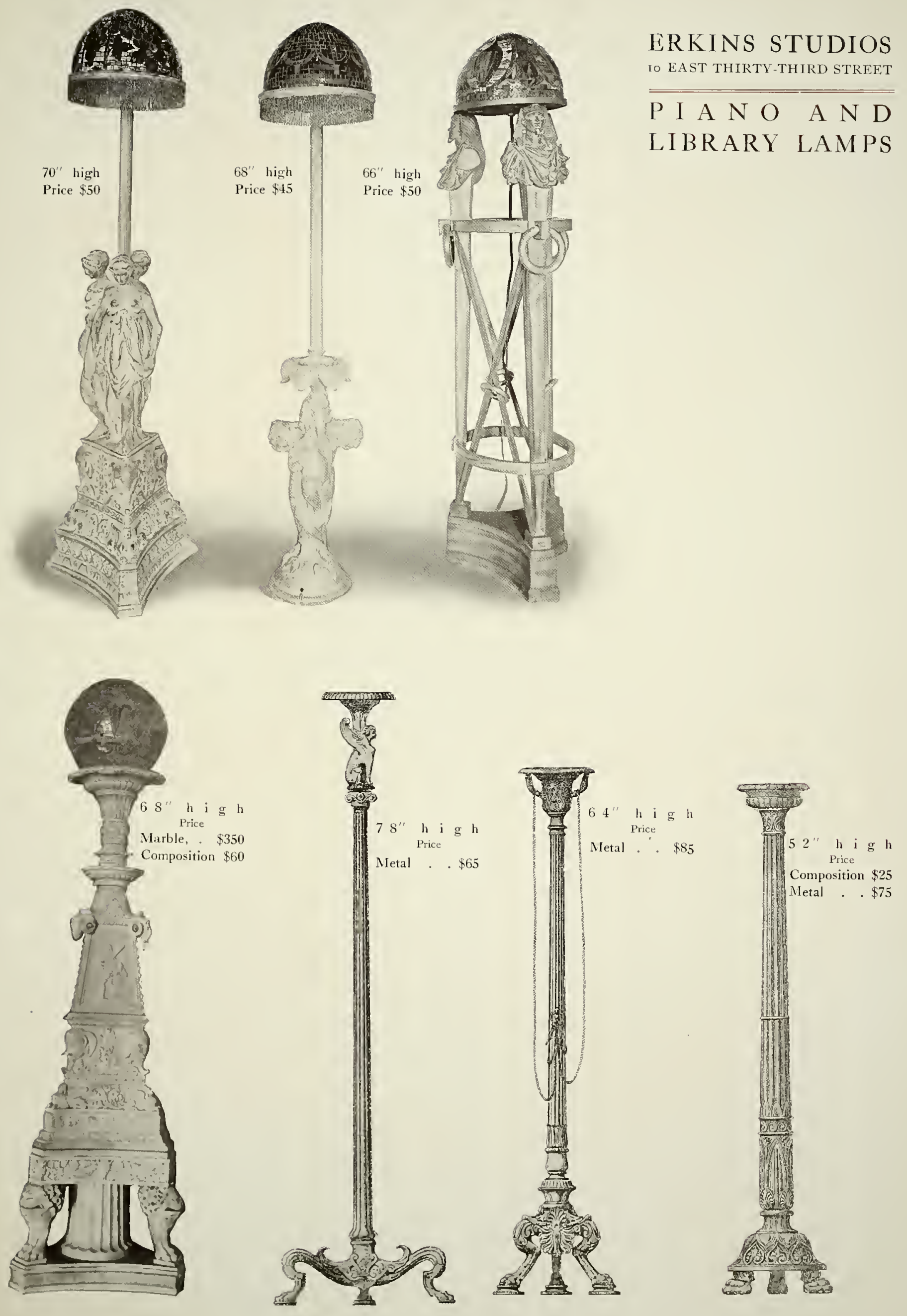


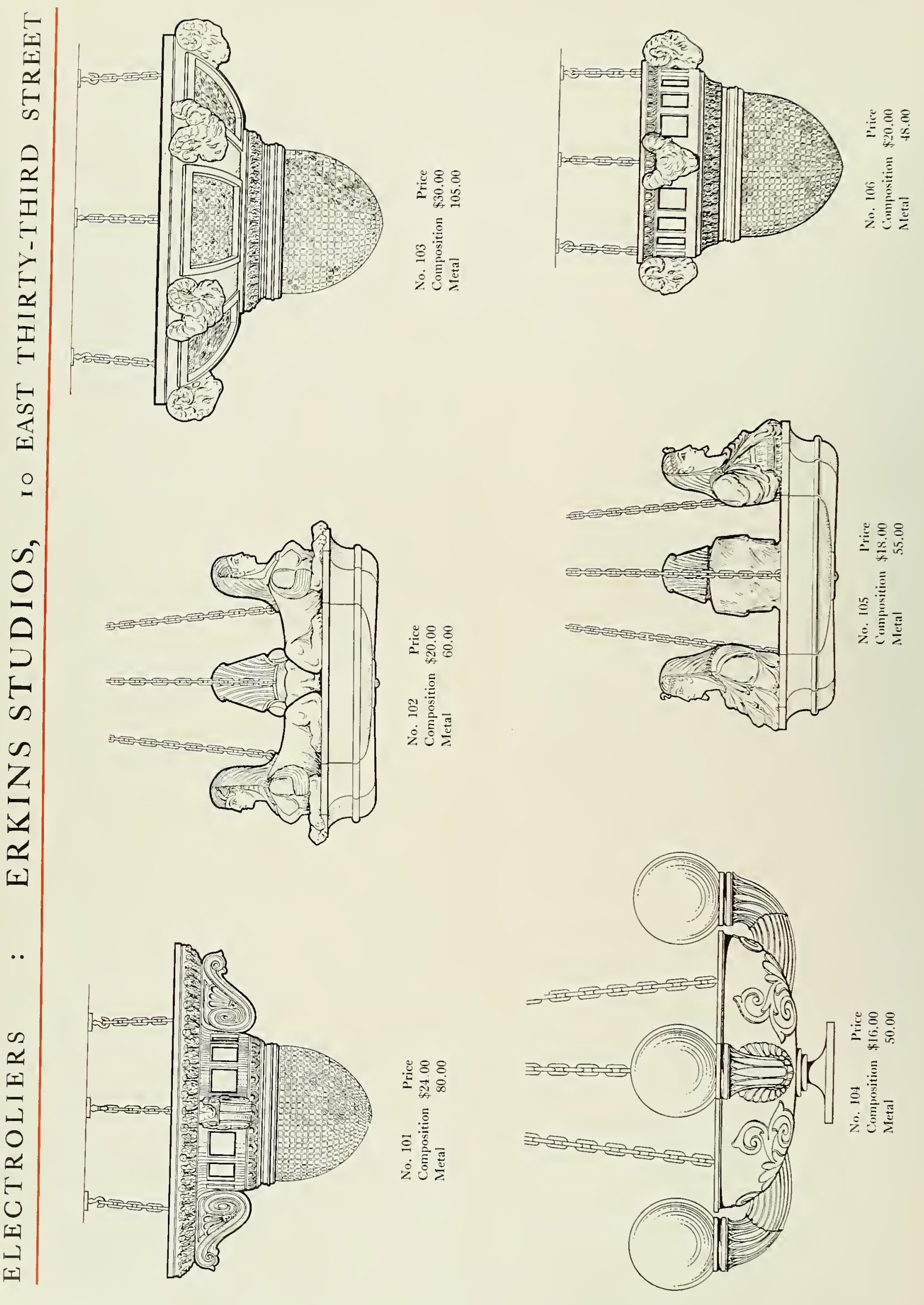




\section{HENRY ERKINS STUDIOS}

I O EAST THIRTY-THIRD S'TREET

WILL DESIGN RESTAURANTS,

H O T E L S, GAR D E N S, E T C.

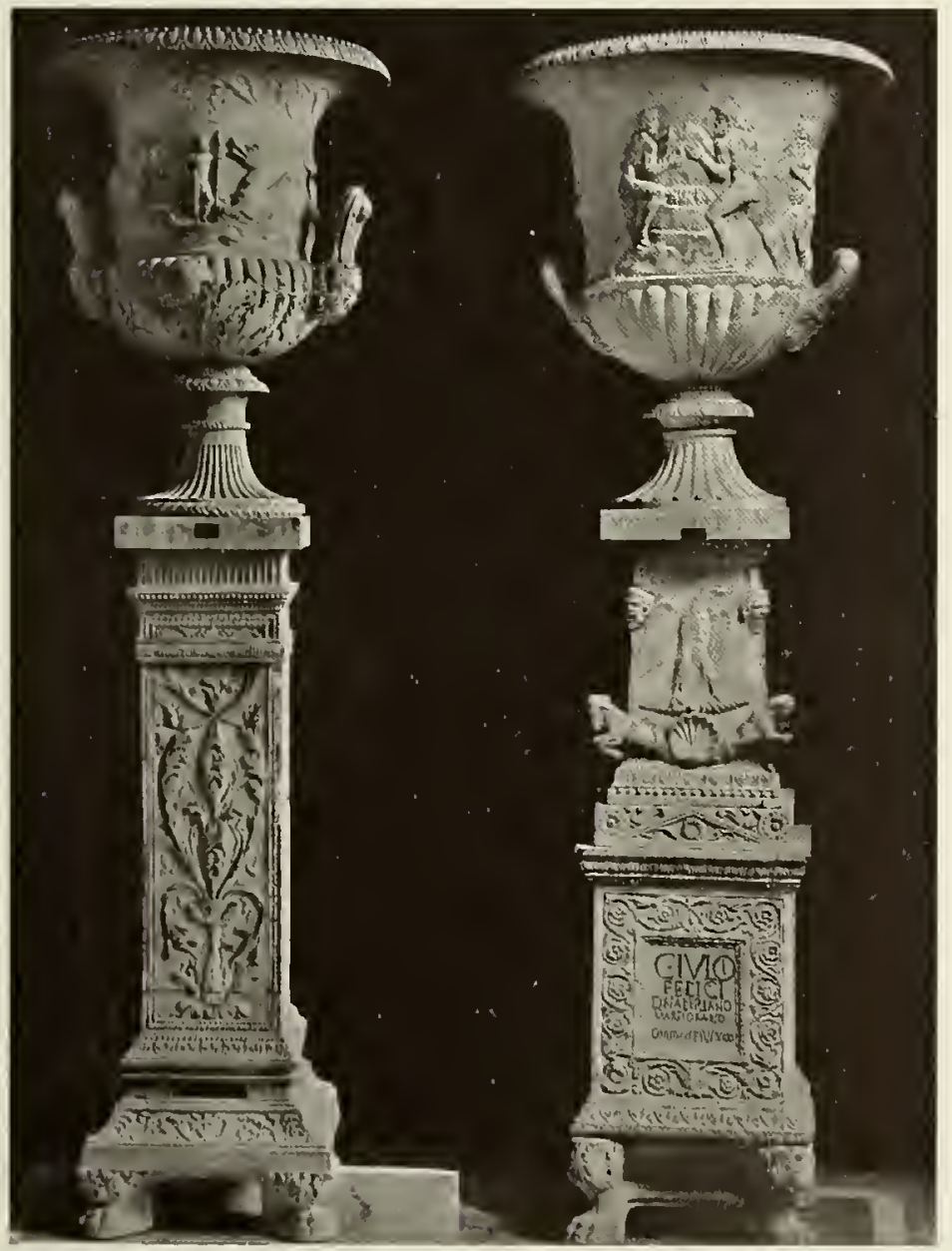

ERKINS STUDIOS

10 EAST THIRTY-THIRD STREET

MARBLES FOR GAR-

DENS, HALLS, ETC.

ALL ARTICLES AS ILLUSTRATED IN THIS BOOK CAN BE OBTAINED FROM HENRY ERKINS STUDIOS

I O EAST THIRTY-THIRD STREET 

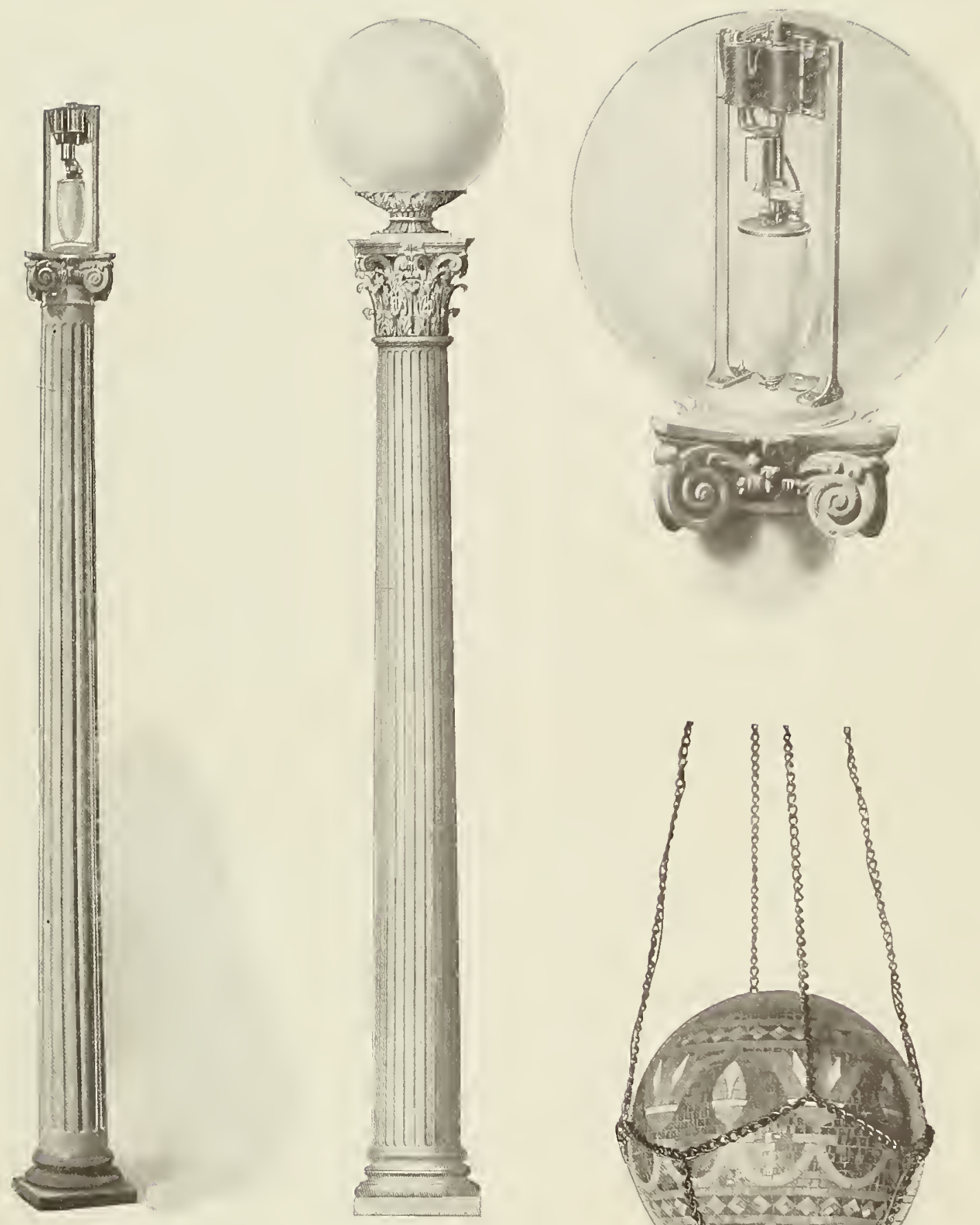

PRICES ON

APPLICATION

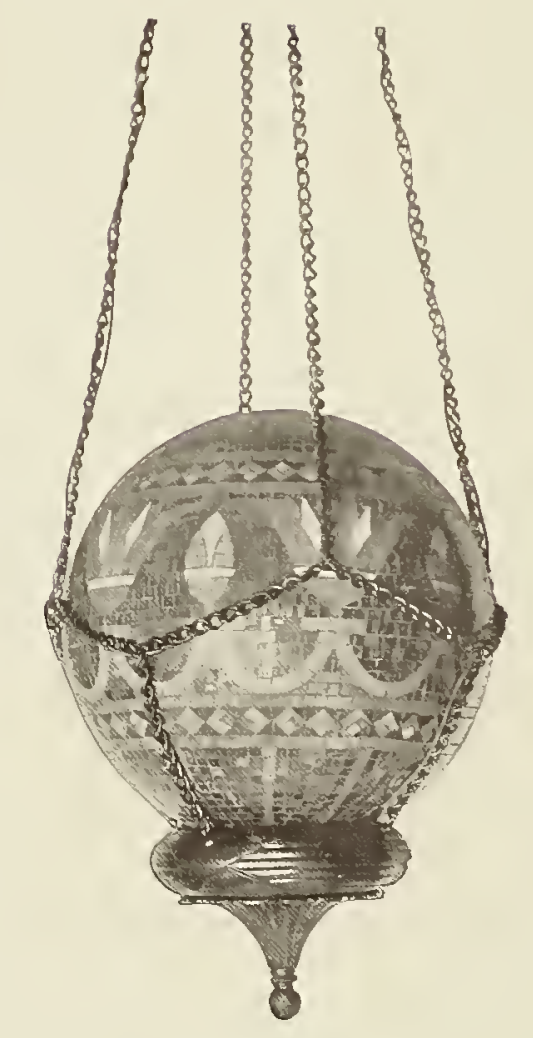

JANDUS ORNAMENTAL LI GHTI N G SPECIALTIES ORNAMENTAL LAMP POSTS CANDELABRAS, WALL B R A CKETS

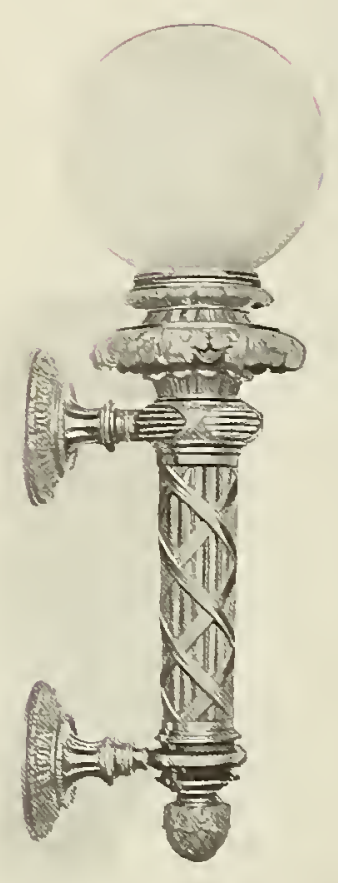

zd STREET छ AVENUE A, NEW YORK 

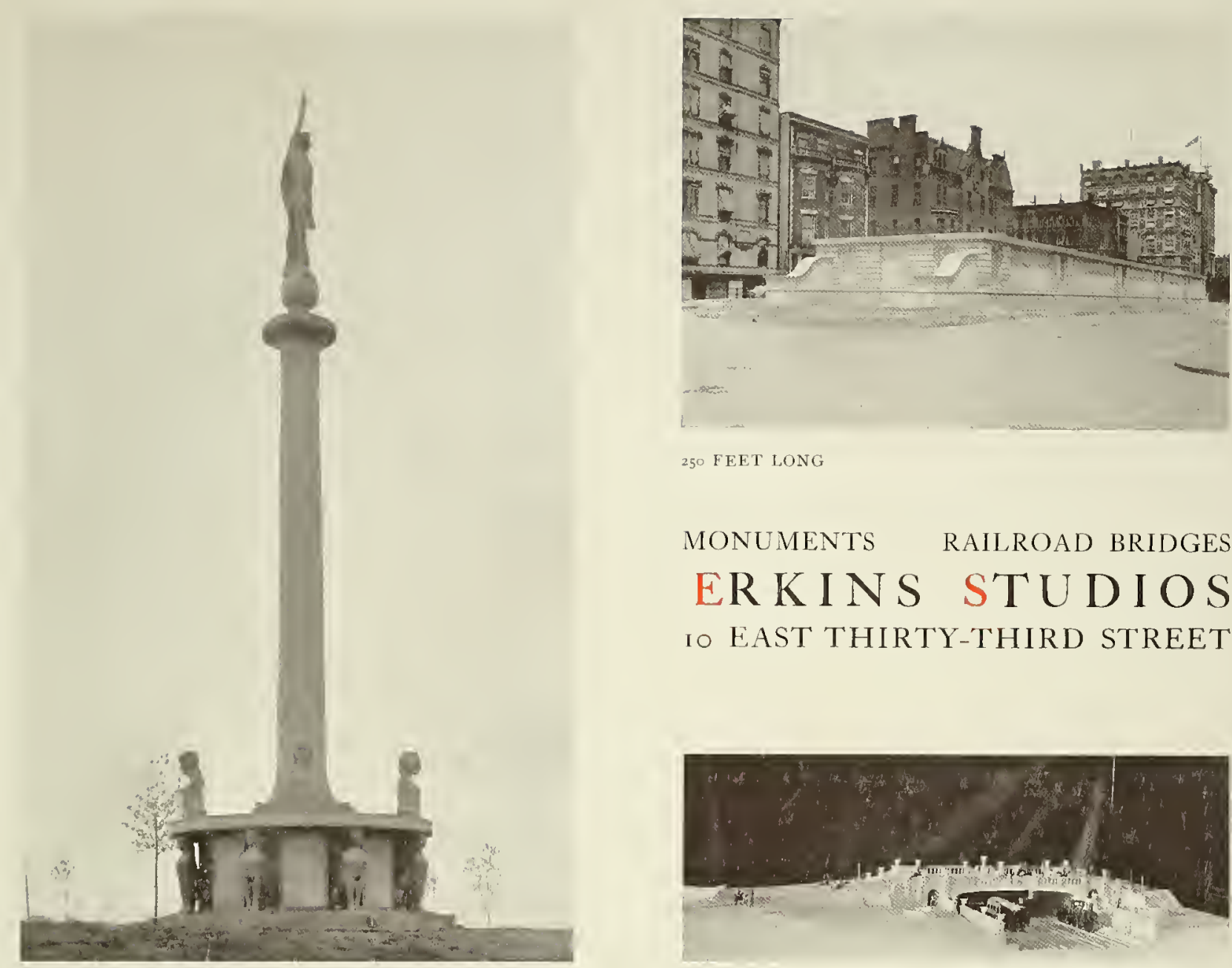

250 FEET LONG

MONUMENTS RAILROAD BRIDGES ERKINS STUDIOS Io EAST THIRTY-THIRD STREET

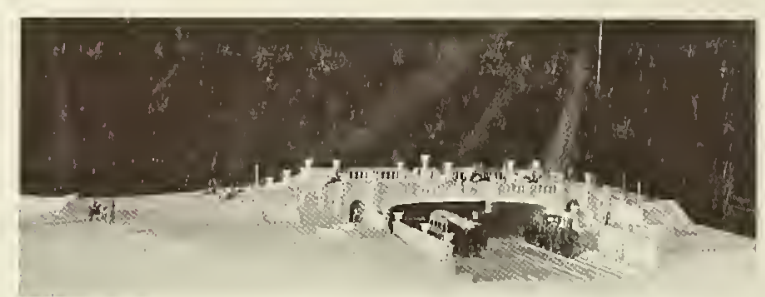

“MURRAY'S" PRIVATE DINING ROOMS INDIVIDUAL DECORATIONS FOR ALL OCCASIONS

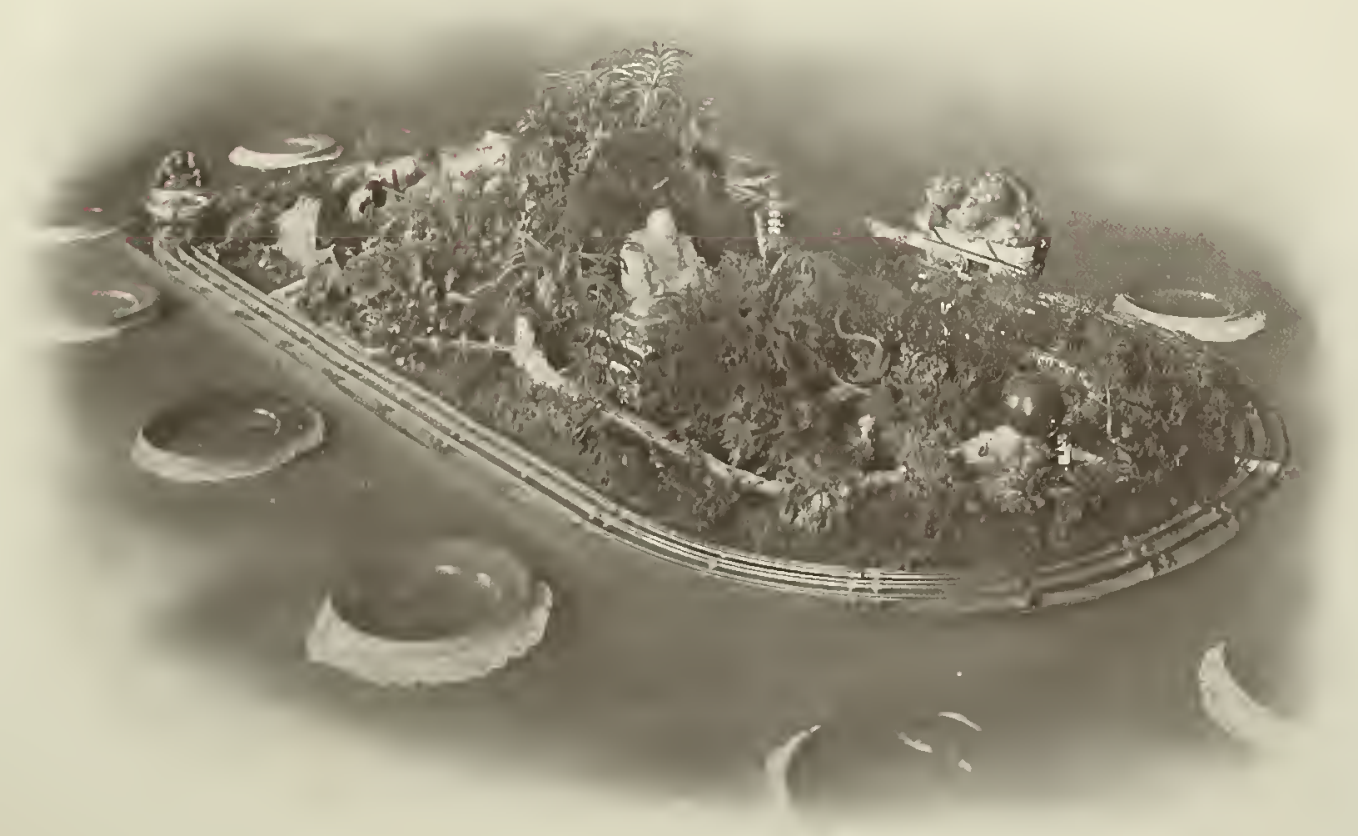

CHINESE TABI,E DECORATION ELECTRIC FOUNTAIN, ELECTRIC CAR, ETC.

"MURRAY'S," FORTY-SECOND STREET AND BROADWAY 

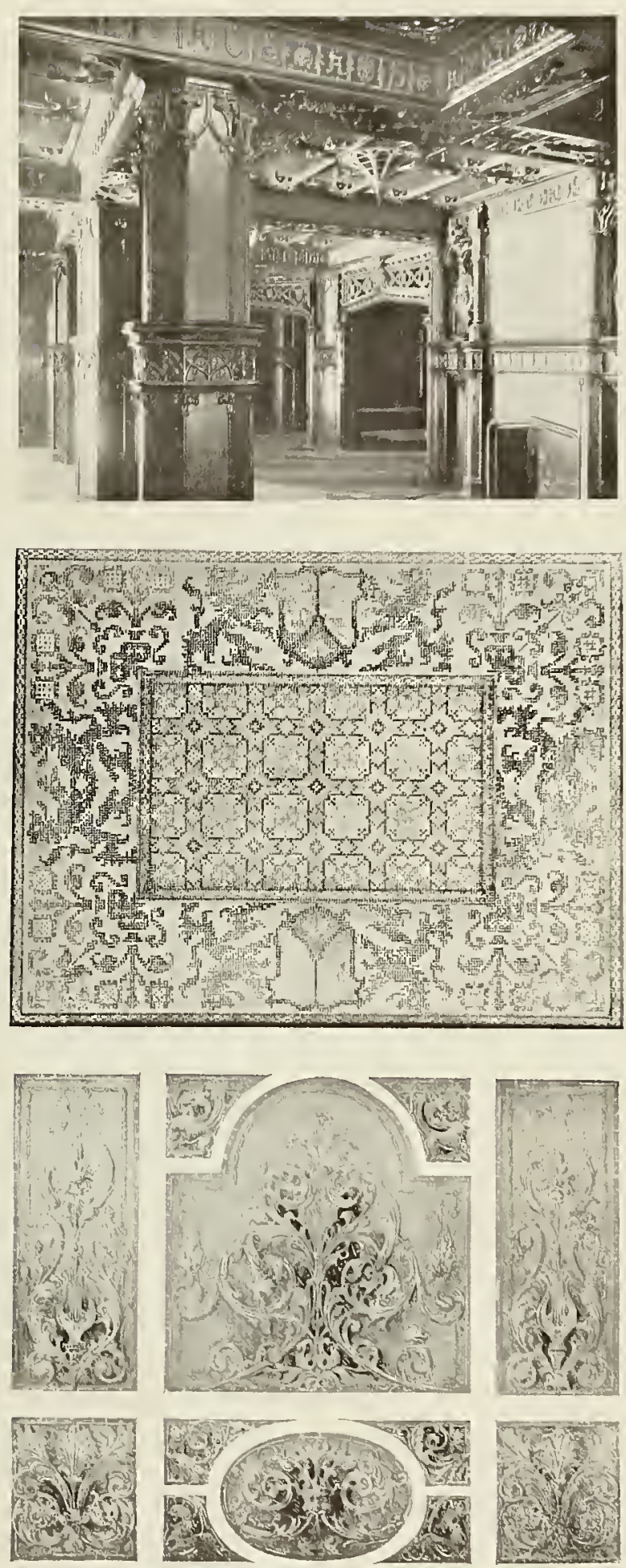

\section{HENRY ERKINS STUDIOS}

10 EAST THIRTY-THIRD STREET, NEW YORK

HALLS

MOSA I C S

STA I NED GLASS

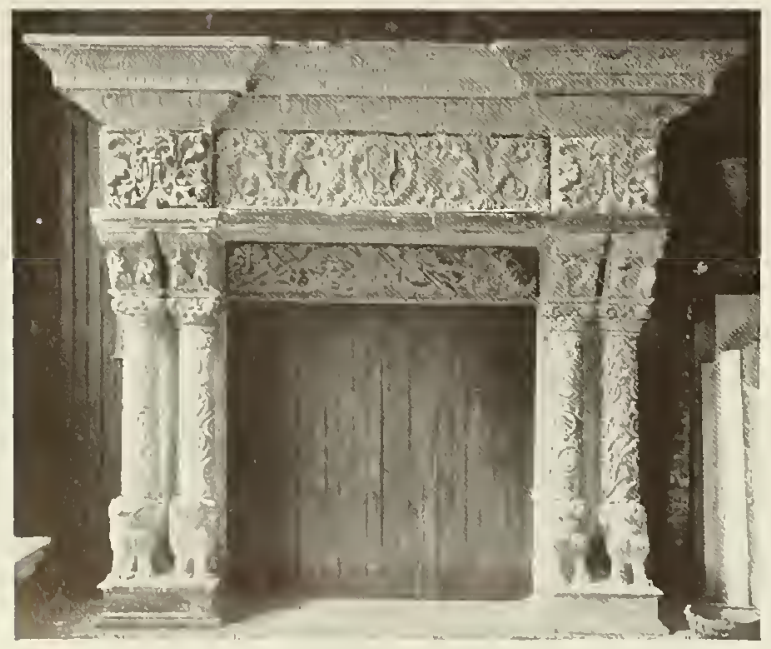



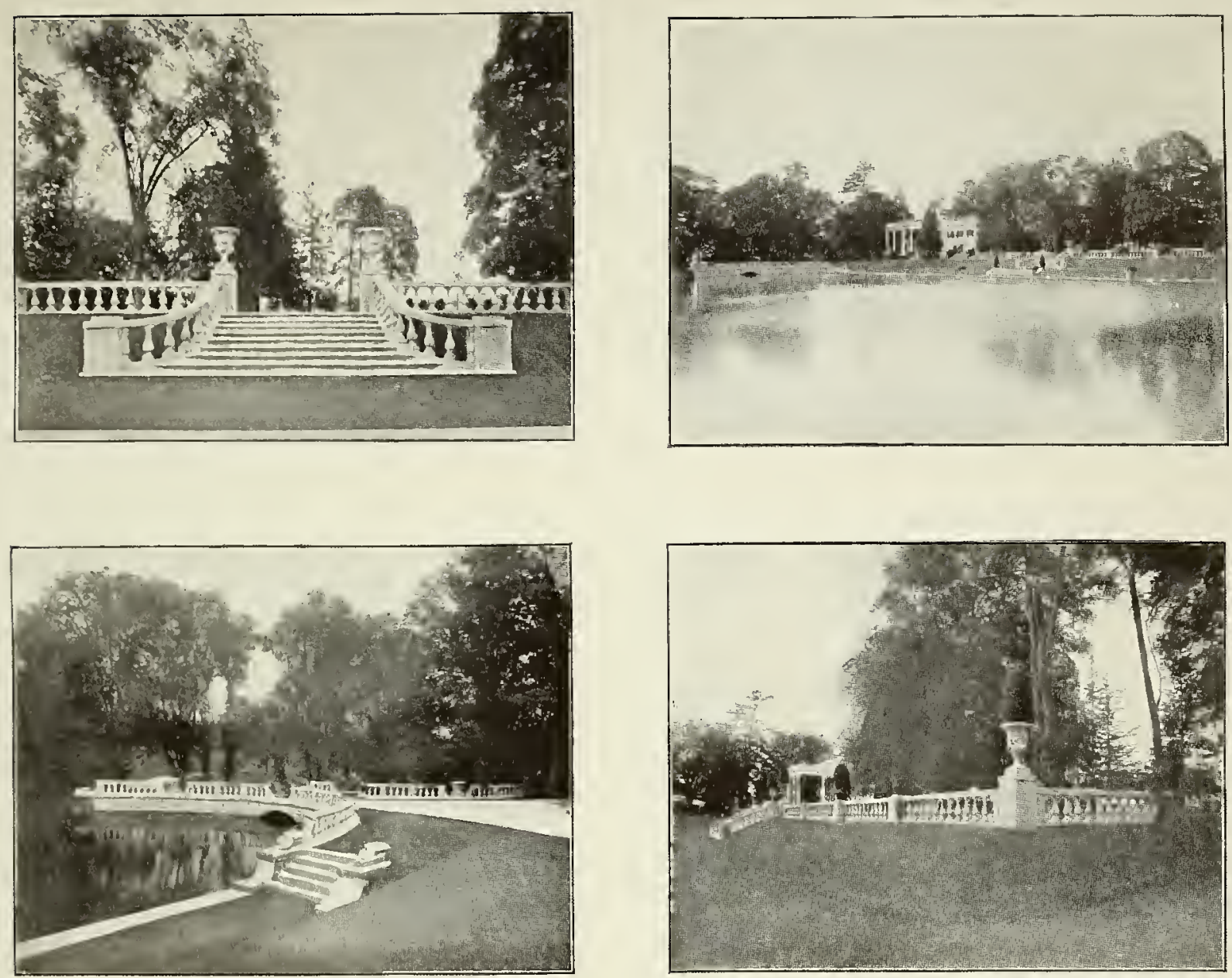

HENRY ERKINS STUDIOS IO EAST THIRTY-THIRD STREET

DESIGN A N D FURNISH G A R D E N S
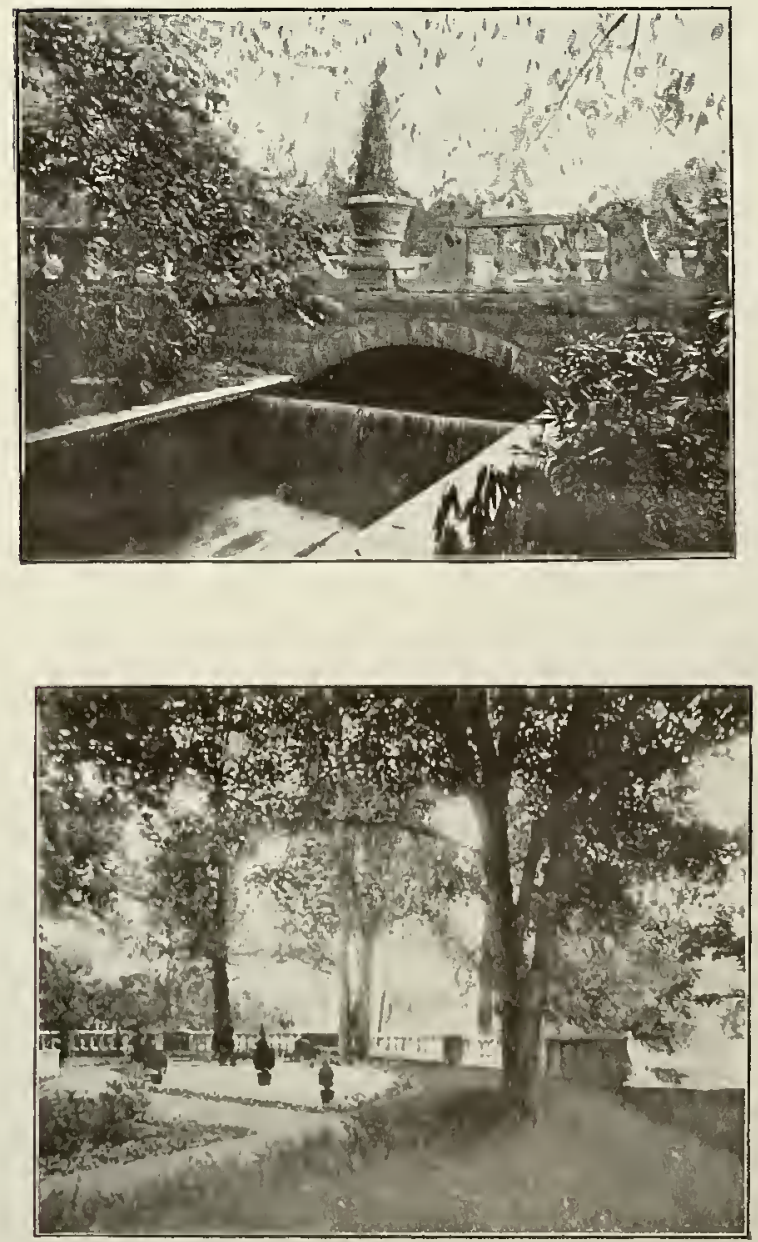


\section{An Appreciation}

The production of a printed work of this magnitude and artistic planning, reflects in the perfection of its execution, a measure of credit upon all who have combined their talents and application in its making.

Mr. Frank Fleming conceived the book, in scheme and detail, and the letter press is credited to Rogers \& Company, Chicago and New York, Engravers and Printers. The "Rogers Quality" stands pre-eminent in commercial literature and finds its greatest expression in the production of catalogs and booklets, in which work Rogers \& Company realize a superior merit.

The plates which have reproduced the decorative and architectural charms of the buildings described were fashioned by the Royal Engraving Company of New York.

It is proper to record the authorship of the text to $\mathrm{Mr}$. Chas. R. Bevington, and the solicitation and arrangement of the advertising pages to $\mathrm{Mr}$. Lewis C. Paine. 

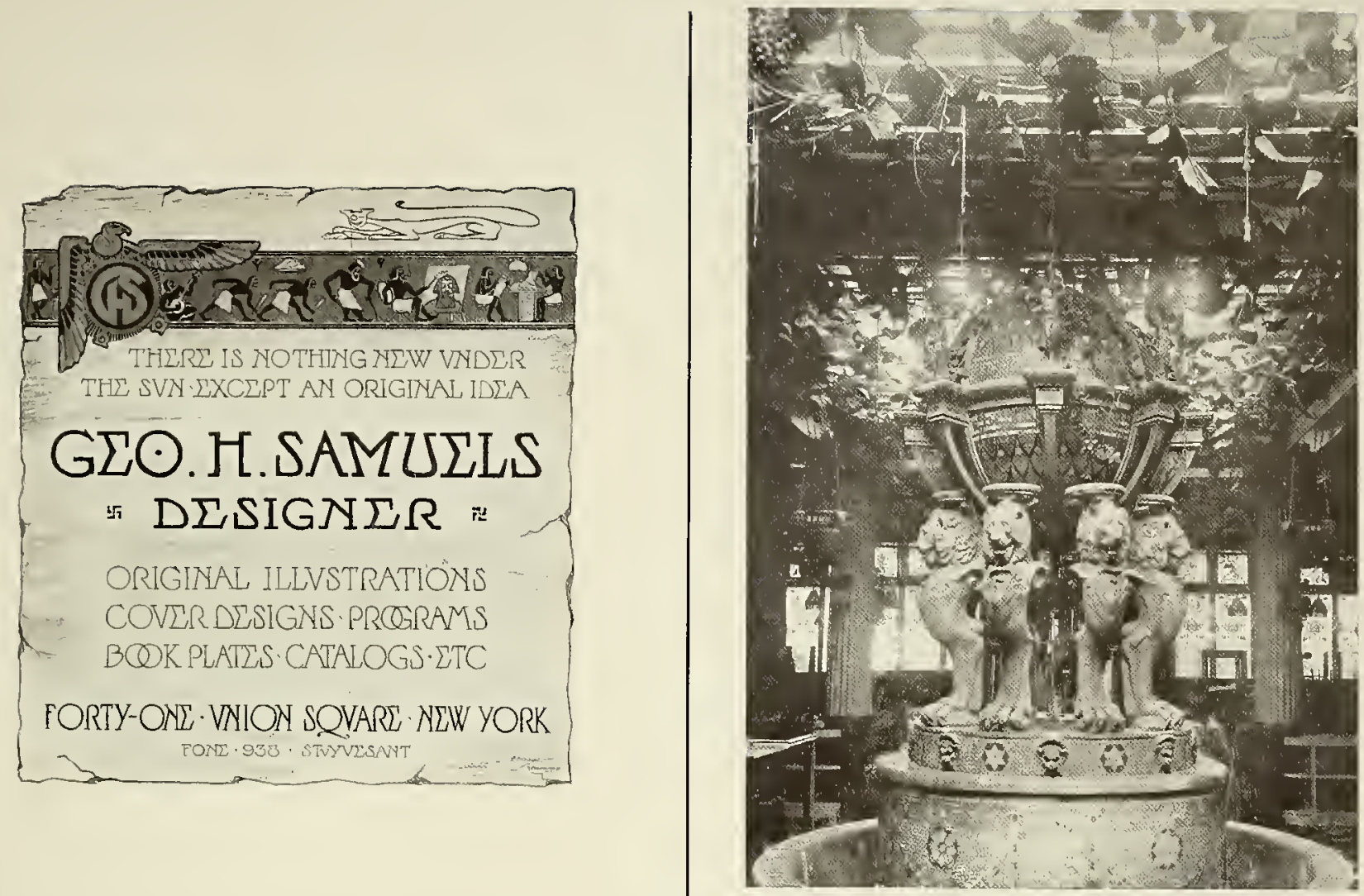

FOUNTAINS FOR DINING ROOMS AND CAFÉS JOHN J. WISE - - 10 EAST 33RD STREET

\section{Murray's New Broadway}

Forty-Second Street and Seventh Avenue

Three acres of floor space devoted exclusively to Dining Room

Opening Beginning of 1909

\section{ARCHAUMBAULT \\ BROADWAY AND 102 D STREET \\ RESTAURANT}




\section{NEW •YORK・ PLAISANCE}
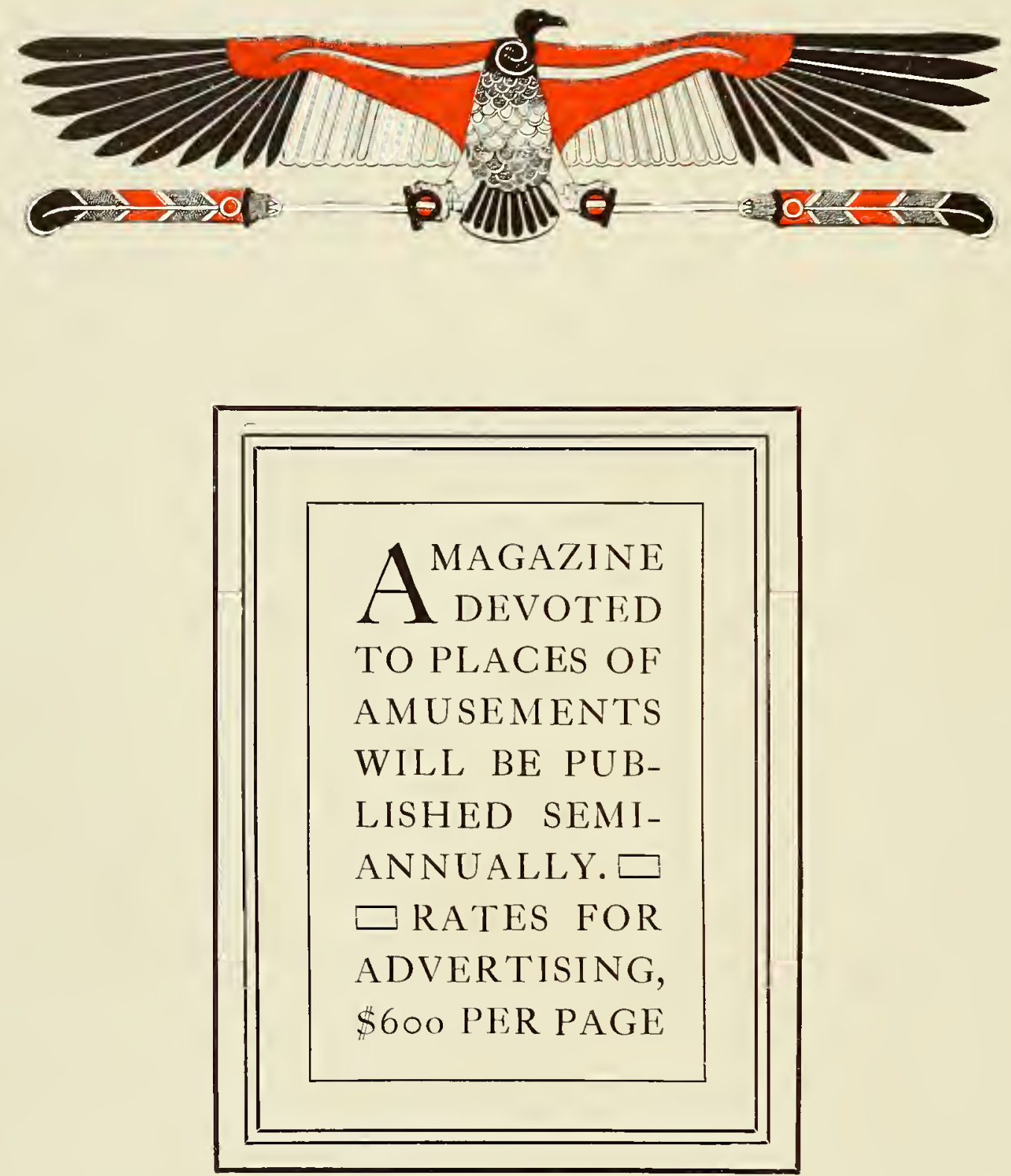

NEW YORK PLAISANCE I $\circ$ E. 33 D ST., NEW YORK

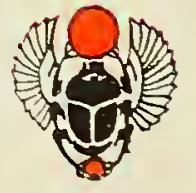






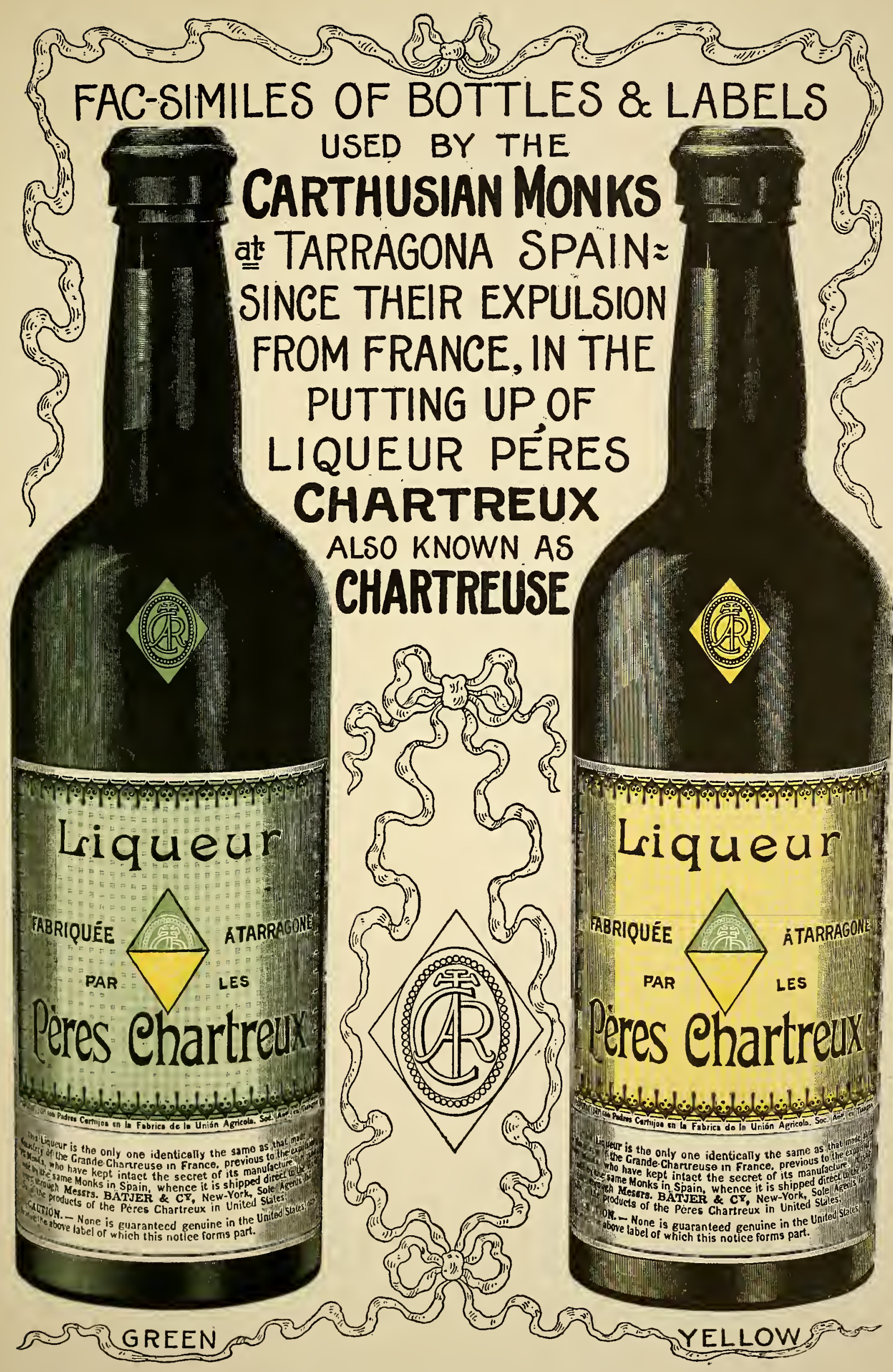




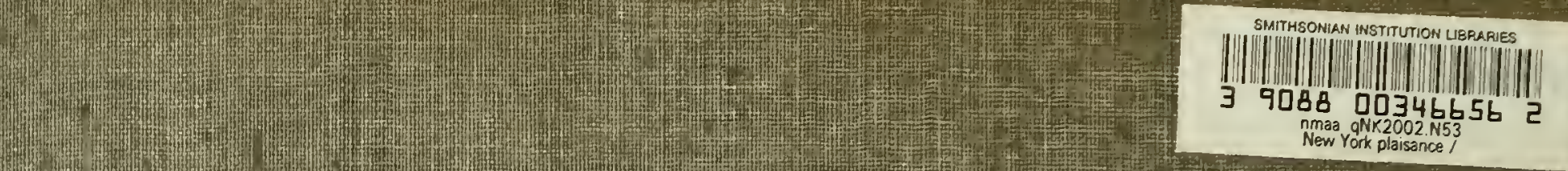

6.7.t.

(1)

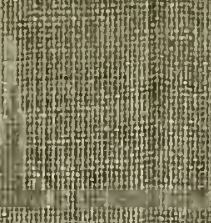

(1)

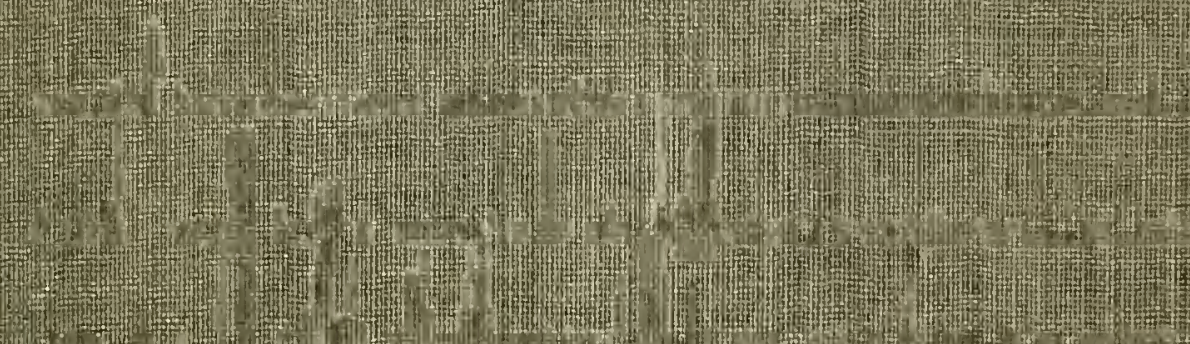

(1)

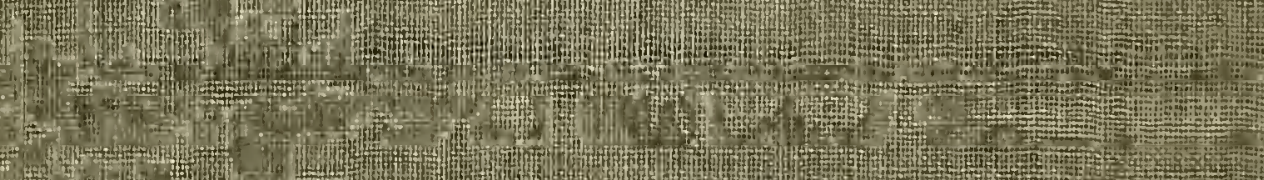

Pat

(1)

(1)

(1)

(1)

H.

(1)

H.

1.

(1) 